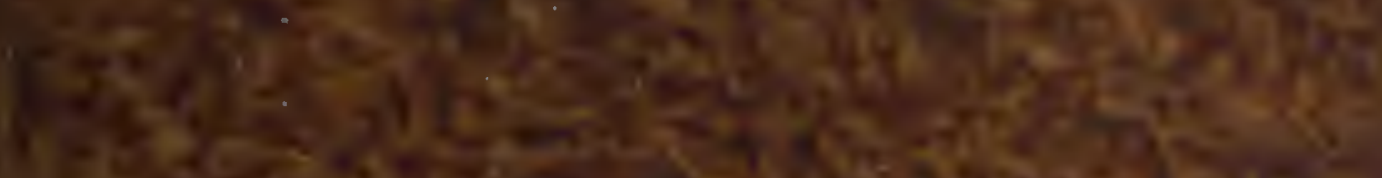

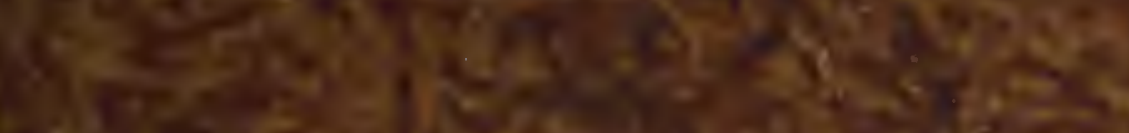

$-\pi$ a

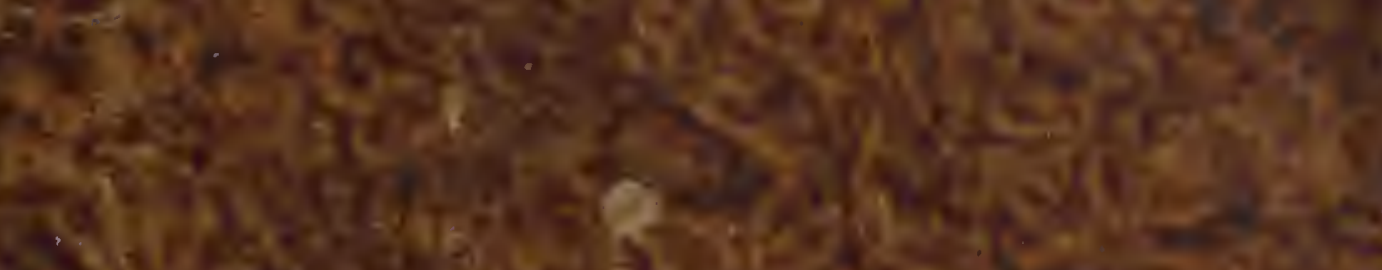

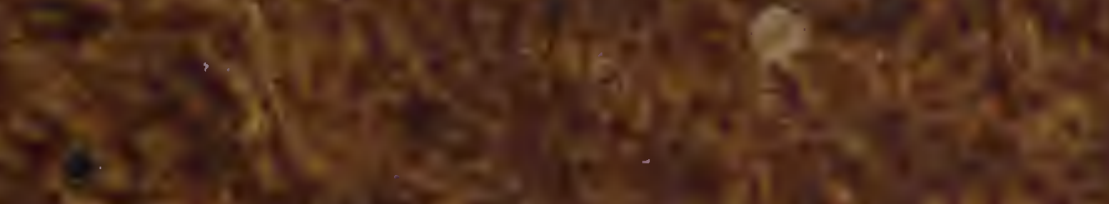

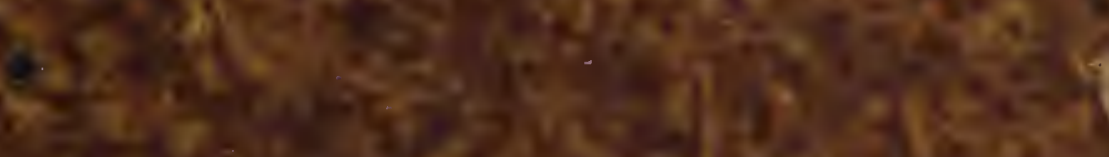

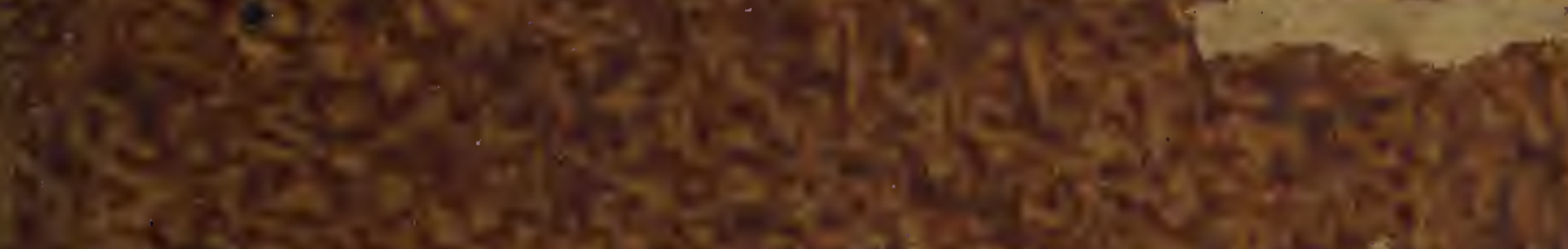

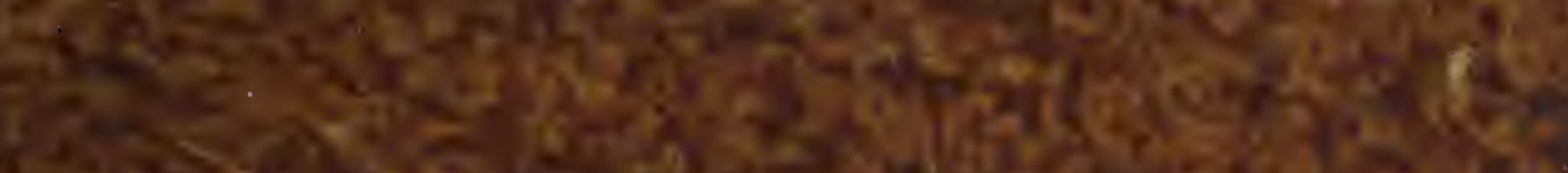

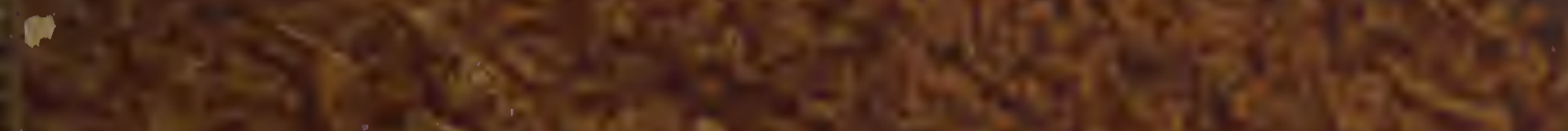

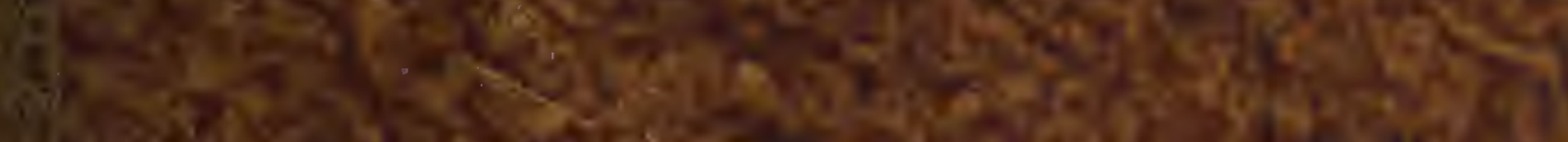

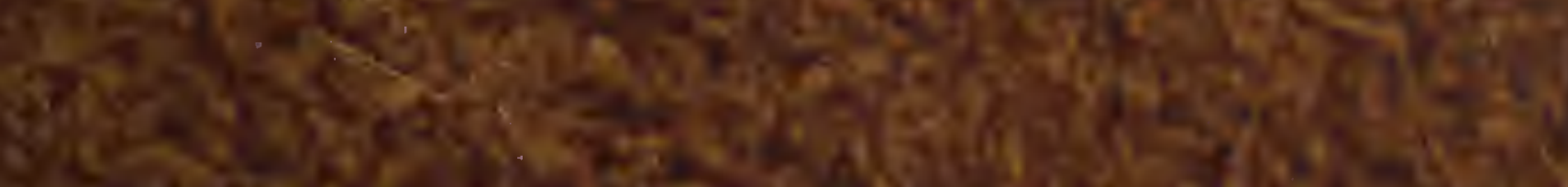
(1)

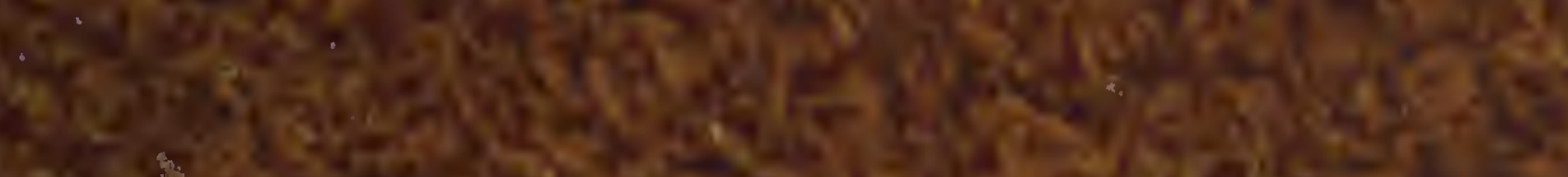

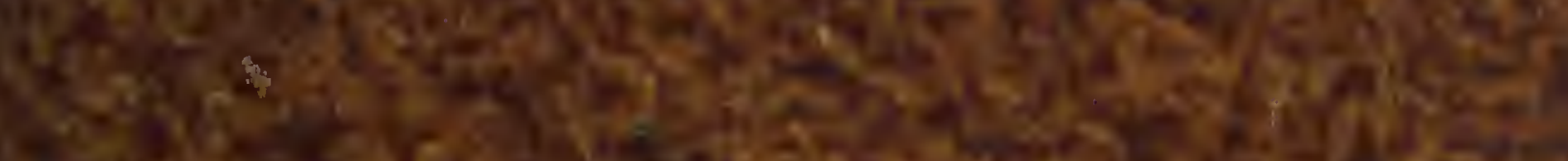
wow

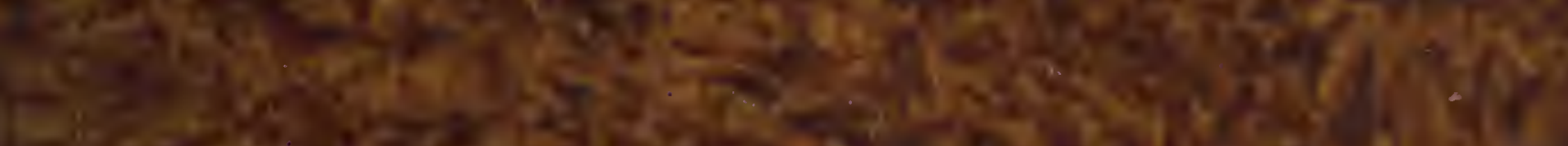

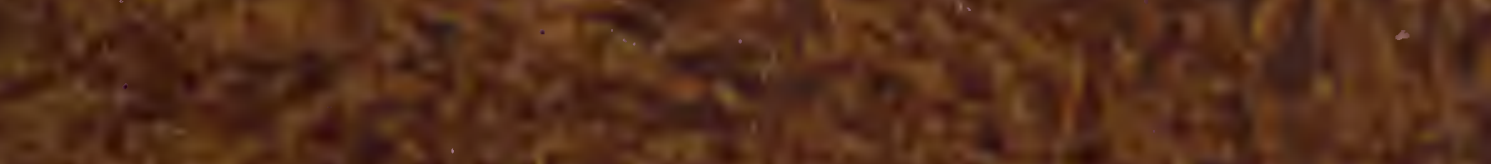

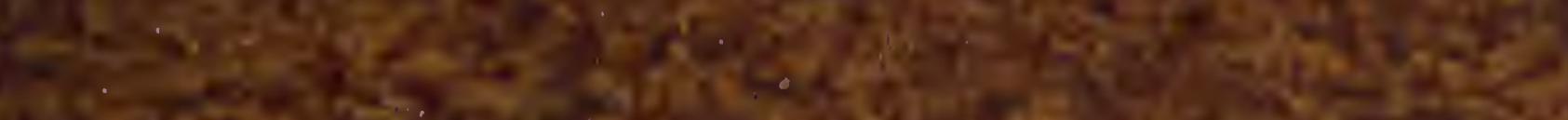

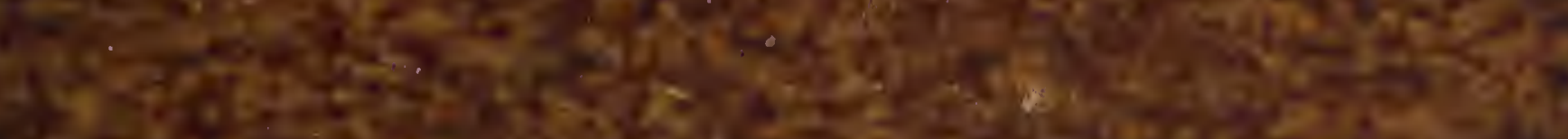

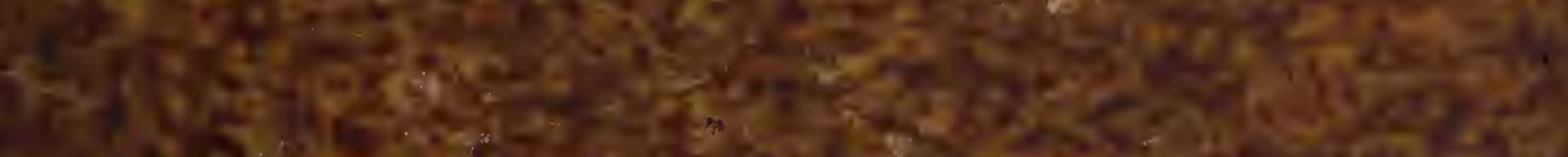

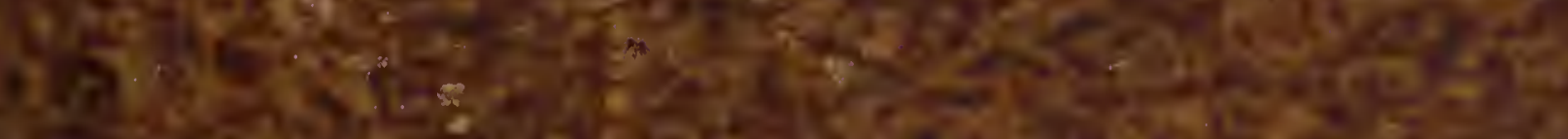
2.

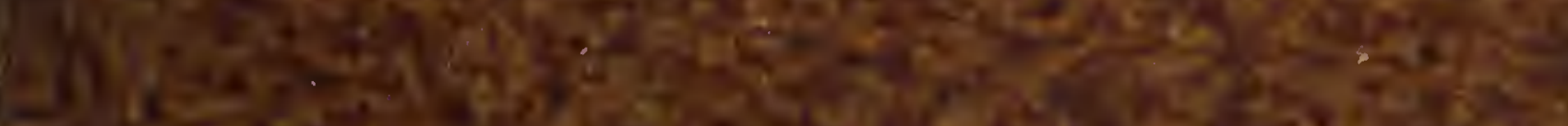

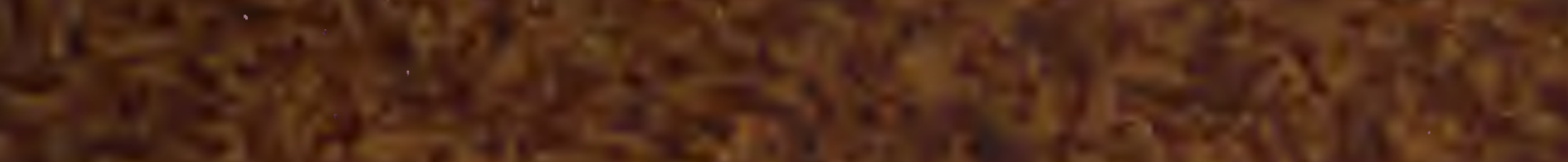

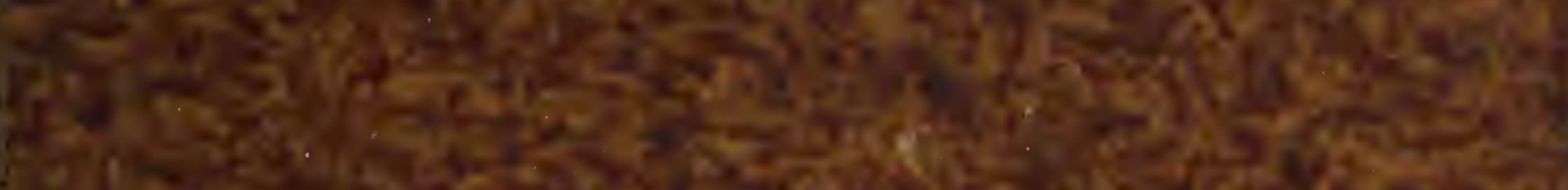

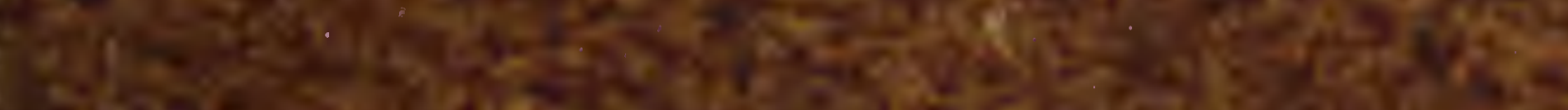

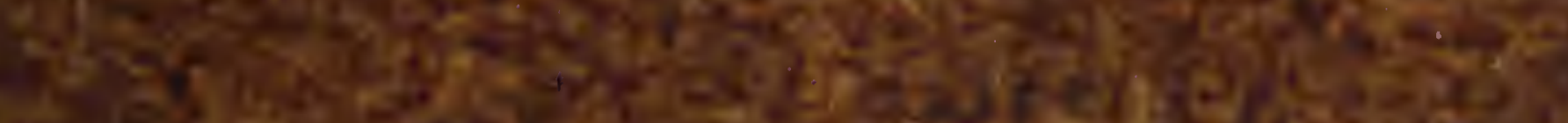

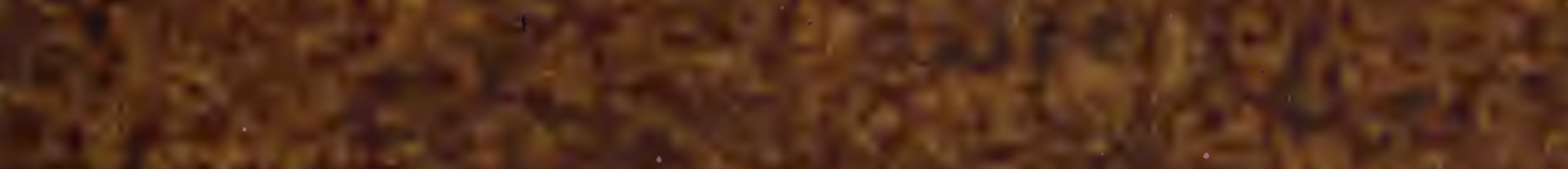

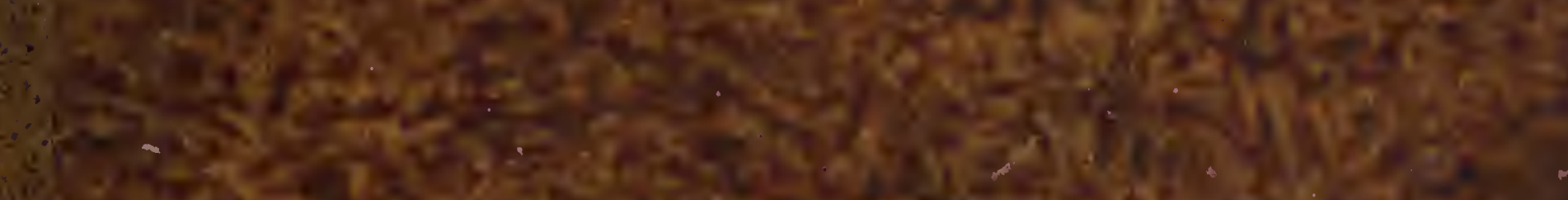

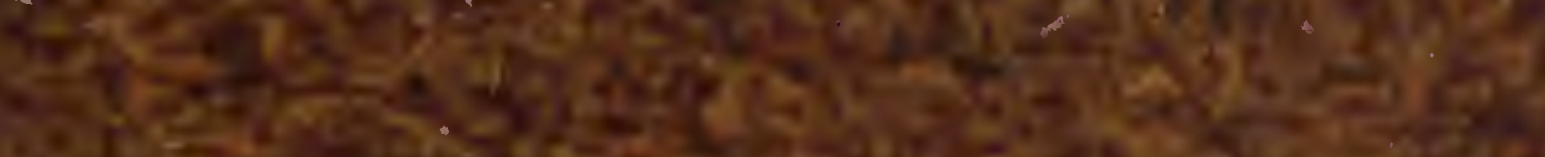

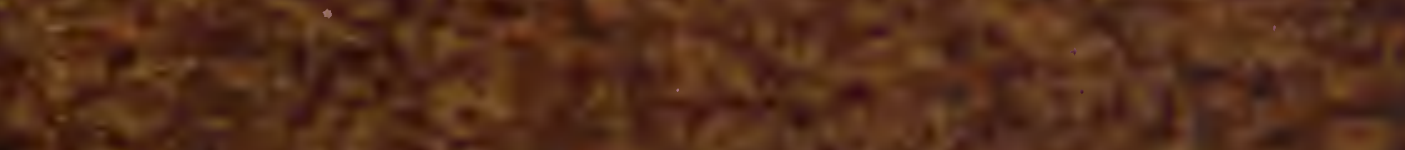

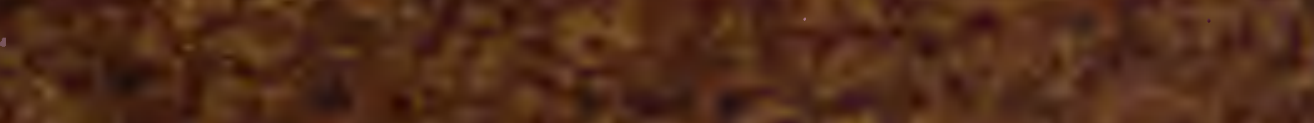

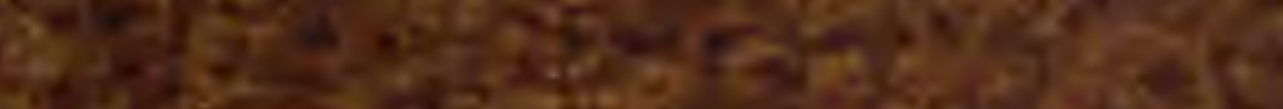

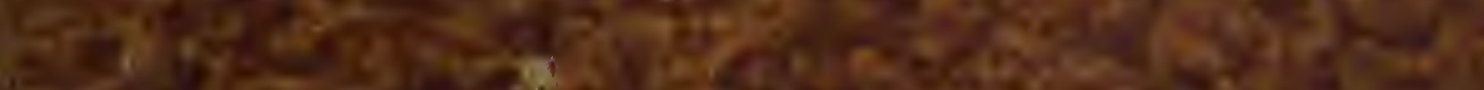

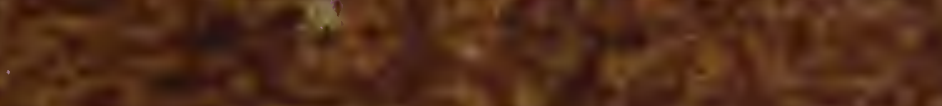



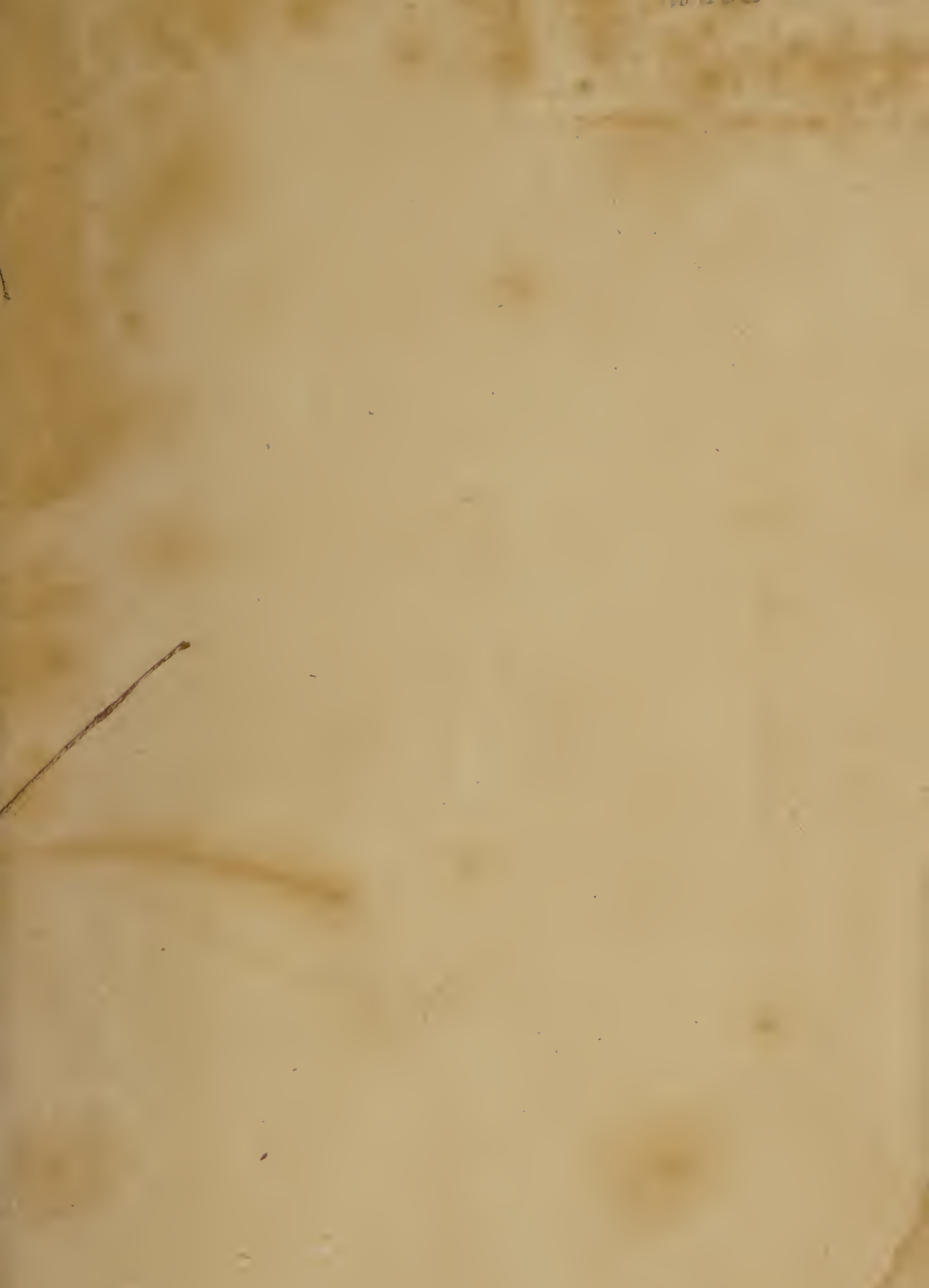

t. I. Leniesta 



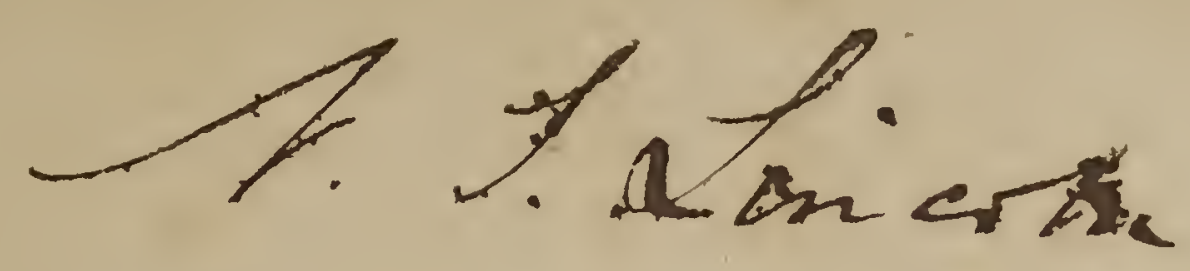

\section{MEMOIRS OF THE LIFE。}

\section{OF \\ DR. DARWIN,}

CHIEFLY DURING HIS RESIDENCE IN LICHFIELD,

WITH

ANECDOTES OF HIS FRIENDS,

AND

CRITICISMS ON HIS WRITINGS.

BY ANNA SEWARD.

$=$

PHILADELPHIA:

AT THE Classí JPtess, FOR THE

PROPRIE'TORS

WM. POYNTELI, \& Co.

1804 



\section{RIGHT HONOURABLE}

\section{THE EARL OF CARLISLE.}

\section{MY LORD,}

W HERE hereditary honours, splendid fortune, and personal graces, have secured, from the first dawn of youth, the external respect and gratifying attention of the world, it is seldom found that their possessor has emulously and sedulously distilled the sweetness from the classic fountains. There is no flattery in observing, that of those rare instances your Lordship is conspicuously one. Such energetic industry involves a superior claim to estimation than where it has appeared the only means by which native talent and laudable ambition could have pierced the mists of obscurity.

You, Sir, have nobly chosen to adorn your rank, instead of indolently leaning upon its inherent distinct. tion, or even satisfying yourself with the acquirement of senatorial eloquence. Professedly a disciple of the Muses, and on public proof an highly-favoured disciple, you must be interested in the life and character of one of the most eminent of your poetic contemporaries. 
Hence, my Lord, do I presume to lay these Memoirs of Dr. Darwin at your feet. From all I hear of Lord Carlisle's virtues, as from all I know of his genius, it is one of my first wishes for this little Tract, that it may interest and amuse a transient hour of his leisure, and obtain that approbation from him which must reward biographic integrity, while literary reputation brightens in his smile.

I have the honour to be, with the most perfect respect and esteem,

\author{
My Lord, \\ Your Lordship's faithful \\ and obedient servant,
}

ANNA SEWARD. 


\section{PREFACE.}

IN publishing these Memoirs of the Life and Writings of Dr. Darwin, I am conscious of their defects ; that they do not form a regular detail of biographical circumstances, even in that moiety. of his professional existence formed by his residence at Lichfield; while of that which passed at Derby I am qualified to present no more than a merely general view.

My work consists of the following particulars: the person, the mind, the temper of Dr. Darwin; his powers as a Physician, Philosopher, and Poet; the peculiar traits of his manners; his excellencies and faults; the Petrarchan attachment of his middle life, more happy in its result than was that of the Bard of Vaucluse; the beautiful poetic testimonies of its fervour, while yet it remained hopeless; an investigation of the constituent excellencies and defects of his magnificent poem, the Botanic Garden; remarks upon his philosophic prose writings; the characters and talents of those 
who formed the circle of his friends while he resided in Lichfield; and the very singular and interesting history of one of them, well known in the lettered world, whose domestic history, remarkable as it is, has been unaccountably omitted by the gentleman who wrote his life.

Dr. Darwin's Letters make no part of these Memoirs. Possessing few of them myself, and those perfectly inconsequential, no effort has here been made to obtain them from others. He lived not, like Pope and Swift, Gray and Johnson, in exclusive devotion to abstract literature. During such hours of repose, compared to his busy and hurried life, he might have found leisure to pour his imagination and his knowledge on the epistolary page; but his epistles, though professionally numerous, were short from necessity, and by choice compressed. He has often said that he had not the talent of elegant letter-writing. Like all other distinguished acquirements, it can only obtain excellence from frequent and diffuse practice, unrestraincd by the interfering pressure of extrinsic considerations.

It was also his frequent remark, that literary fame invariably suffers by the publication of every thing which is below the level of that celebrity which it has already gained. Letters, through 
whose progress either wit scatters its scintillations, criticism its instruction, knowledge its treasures, or fancy its glow, are not beneath the dignity of the most eminent reputation; but since coercive circumstances in a great measure precluded those effusions to the letters of Darwin, there would be no kindness to his memory in obtruding them upon the public; none to the public in swelling out books with materials of no intrinsic value. It is only zeal without judgment, and the enthusiasm of partiality, which can take pleasure in reading a great man's letters, which might have been those of any tolerably educated mind, on which genius had never shone.

Biography of recently departed Eminence is apt to want characteristic truth, since it is generally written either by a near relation,

Who writes to share the fame of the deceased,

So high in merit, and to him so dear!

Such dwell on praises which they think they share *;

or by an highly obliged friend, whom gratitude and affection render blindly partial, and who is influenced by a desire of gratifying, with a descrip-

* Young's Night Thoughts. 
tion of all-excelling endowment and angelic excellence, the surviving family of the author he commemorates; or by an editor who believes it highly conducive to his profits on the writings he publishes or republishes, to claim for their author the unqualified admiration and reverence of mankind. All these classes of biographers do for the person whom they commemorate, what our generally wise Queen Elizabeth had the weakness to request her painters would do for her portrait on the canvass; they draw a picture without shades.

But though people of credulous and effervescent zeal may be gratified by seeing a writer, whose works have charmed them, thus invested with unrivalled genius and super-human virtue, the judicious few, whose approbation is genuine honor, are aware of this truth, asserted by Mrs. Barbauld in her beautiful, her inestimable Essay against Inconsistency in our Expectations: " $\mathrm{Na}$ " ture is much too frugal to heap together all man" ner of shining qualities in one glaring mass *." Every man has his errors, and the errors of public characters are too well known not to expose unfounded eulogium to the distaste of all who prefer truth to enthusiasm. They are conscious that the 
mind, as well as the person, of a celebrated character, ought to be drawn with dispassionate fidelity, or not attempted; that though just biographic record will touch the failings of the good and the eminent with tenderness, it ought not to spread over them the veil of suppression. A portrait painter might as well omit each appropriate distinction of feature, countenance, and form, because it may not be elegant, and, like the Limner in Gay's Fables, finish his pictures from casts of the Venus and Apollo, as the historian conceal the faults, foibles, and weaknesses of the individual whom he delineates.

It is this fidelity of representation which makes Mrs. Piozzi's Memoirs of Dr. Johnson, and Mr. Boswell's Tour, and his Life of that wonderful being, so valuable to those who wish not for an idol to worship, instead of a great man to contemplate, as nature, passion, and habit, compounded his character.

If those biographers had invested their deceased friend with excellence, which no sombre irritability had ever overshadowed; ;... with justice and candour, which no literary jealousy, no party prejudice, no bigot zeal had ever warped;.... the public might have been led, through boundless veneration of one, into injustice towards many. The world might have been induced to believe that all whose 
merit he has depreciated, whose talents he has undervalued, through the course of his Lives of the Poets, had deserved the fate they met on those pages. Then, to the injury of our national taste, and to the literary and moral character of the great English Classics, more universal confidence had been placed in the sophistries of those volumes, which seem to have put on the whole armour of truth by the force of their eloquence and the wit of their satire.

A paragraph which appeared in several of the late newspapers, and which contained a ridiculously false print, political for poetical, mentioned that these expected Memoirs were undertaken at the request of the late Dr. Darwin's family. A mistaken rumour; though they certainly had their rise in the expressed desire of Dr. Robert Darwin of Shrewsbury, that I would supply him with such anecclotes of his father's earlier life, as my intimacy with him, during that period, had enabled me to obtain, and which might assist in forming a biographic sketch, to be prefixed to his writings at some future time. In purposed obedience these records were begun, but they became too extended to form only materials for another person's composition; and too impartial to pass with propriety 
through the filial channel, though fervently just to the excellencies of the commemorated.

Of those years in which the talents and social virtues of this extraordinary man shed their lustre over the city which I inhabit, no historian remains, who, with vicinity of habitation, and domestic intercourse with Dr. Darwin, took equal interest with myself in all that marked, by traits of him, that period of twenty-three years, and which engaged my attention from my very earliest youth. Some few of his contemporaries in this town yet remain; but not one who could be induced to publish what their observation may have traced, and their memory treasured.

His sometime pupil, and late years friend, the ingenious Mr. Bilsborrow, is writing, or has written, his Life; but since Dr. Darwin constantly shrunk with reserved pride from all that candour would deem confidential conversation, and which the world is so apt to ridicule as vain egotism; since it is understood that he had not left biographic documents; since Mr. Bilsborrow was scarcely in existence when his illustrious friend first changed his sphere of action; he must find himself as much a stranger to the particulars of his Lichfield residence, as I am of those which were most prominent in the equal number of years he passed at Derby, 
Between us, all will probably be known that can now with accuracy be traced of Dr. Darwin.

To the best of my power I have presumed to be the recorder of vanished Genius, beneath the ever-present consciousness that biography and criticism have their sacred duties, alike to the deceased, and to the public; precluding, on one hand, unjust depreciation, on the other, over-valuing partiality. 


\section{MEMOIRS}

or

THE LIFE AND WRITINGS

or

DOCTOR DARWIN.

CHAP. I.

Doctor Erasmus Darwin was the son of a private gentleman, near Newark, in Nottinghamshire. He came to Lichfield to practise physic in the autumn of the year 1756, at the age of twentyfour; bringing high recommendations from the university of Edinburgh, in which he had studied, and from that of Cambridge, to which he belonged.

He was somewhat above the middle size, his form athletic, and inclined to corpulence; his limbs too heavy for exact proportion. The traces of a severe small-pox; features, and countenance, which, when they were not animated by social plcasure, were rather saturnine than sprightly; a stoop in the shoulders, and the then professional appendage, a large full-bottomed wig, gave, at that early period of life, an appearance of nearly twice the years he 
bore. Florid health, and the earnest of good humour, a sunny smile, on entering a room, and on first accosting his friends, rendered, in his youth, that exterior agreeable, to which beauty and symmetry had not been propitious.

He stammered extremely; but whatever he said, whether gravely or in jest, was always well worth waiting for, though the inevitable impression it made might not always be pleasant to individual self-love. Conscious of great native elevation above the general standard of intellect, he became, early in life, sore upon opposition, whether in argument or conduct, and always revenged it by sarcasm of very keen edge. Nor was he less impatient of the sallies of egotism and vanity, even when they were in so slight a degree, that strict politeness would rather tolerate than ridicule them. Dr. Darwin seldom failed to present their caricature in jocose but wounding irony. If these ingredients of colloquial despotism were discernible in unworn existence, they increased as it advanced, fed by an cver-growing reputation within and without the pale of medicine.

Extreme was his scepticism to human truth. From that cause he often disregarded the accounts his patients gave of themselves, and rather chose to collect his information by indirect inquiry and 
by cross-examining them, than from their voluntary testimony. That distrust and that habit were probably favourable to his skill in discovering the origin of diseases, and thence to his preeminent success in effecting their cure;....but they impressed his mind and tinctured his conversation with an apparent want of confidence in mankind, which was apt to wound the ingenuous and confiding spirit, whether seeking his medical assistance, or his counsel as a friend. Perhaps this proneness to suspicion mingled too much of art in his wisdom.

From the time at which Dr. Darwin first came to Lichfield, he avowed a conviction of the pernicious effects of all vinous fluid on the youthful and healthy constitution; an absolute horror of spirits of all sorts, and however diluted. His own example, with very few exceptions, supported his exhortations. From strong malt liquor he totally abstained, and if he drank a glass or two of English wine, he mixed it with water. Acid fruits, with sugar, and all sort of creams, and butter, were his luxuries; but he always ate plentifully of animal food. This liberal alimentary regimen he prescribed to people of every age, where unvitiated appetite rendered them capable of following it; even to infants. He despised the prejudice, which deems foreign wines more wholesome than the wines of 
the country. If you must drink wine, said he, let it be home-made. It is well known, that Dr. Darwin's influence and example have sobered the county of Derby; that intemperance in fermented fiuid of every species is almost ' unknown amongst its gèntlemen.

Professional generosity distinguished $\mathrm{Dr}$. Darwin's medical practice. While resident in Lichield, to the priest and lay-vicars of its cathedral, and their families, he always cheerfully gave his advice, but never took fees from any of them. Diligently, also, did he attend to the health of the poor in that city, and afterwards at Derby, and supplied their necessities by food, and all sort of charitable assistance. In each of those towns, his was the cheerful board of almost open-housed hospitality, without extravagance or parade; deeming ever the first unjust, the latter unmanly. Generosity, wit, and science, were his household gods.

To those many rich presents, which Nature bestowed on the mind of Dr. Darwin, she added the seducing, and often dangerous gift of a highly poetic imagination; but he remembered how fatal that gift professionally became to the young physicians, Akenside and Armstrong. Concerning them, the public could not be persuaded, that so much excellence in an ornamental science was 
compatible with intense application to a severcr study; with such application as it held necessary to a responsibility, towards which it might look for the source of disease, on which it might lean for the struggle with mortality. Thus, through the first twenty-three years of his practice as a physician, Dr. Darwin, with the wisdom of Ulysses, bound himself to the medical mast, that he might not follow those delusive syrens, the muses, or be considered as thei: avowed votary. Occasional little pieces, however, stole at seldom occurring periods from his pen; though he cautiously precluded their passing the press, before his latent genius for poetry became unveiled to the public eye in its copious and dazzling splendour. Most of these minute gems have stolen into newspapers and magazines, since the impragnable rock, on which his medicinal and philosophical reputation were placed, induced him to contend for that species of fame, which should entwine the Parnassian laurel with the balm of Pharmacy.

After this sketch of Dr. Darwin's character and manners, let us return to the dawn of his professional establishment. A few weeks after his arrival at Lichfield, in the latter end of the year 1756, the intuitive discernment, the skill, spirit and decision, which marked the long coursc of his 
successful practice, were first called into action, and brilliantly opened his career of fame. The late Mr. Inge of Thorpe, in Staffordshire, a young gentleman of family, fortune, and consequence, lay sick of a dangerous fever. The justly celebrated Dr. Wilks of Willenhal, who had many years possessed, in wide extent, the business and confidence of the Lichfield neighbourhood, attended Mr. Inge, and had unsuccessfully combated his disease. At length he pronounced it hopeless; that speedy death must ensue, and took his leave. It was then that a fond mother, wild with terror for the life of an only son, as drowning wretches catch at twigs, sent to Lichfield for the young, and yet inexperienced physician, of recent arrival there. By a reverse and entirely novel course of treatment, Dr. Darwin gave his dying patient back to existence, to health, prosperity, and all that high reputation, which Mr. Inge afterwards possessed as a public mágistrate.

The far-spreading report of this judiciously daring and fortunate exertion brought Dr. Darwin into immediate and extensive employment, and soon eclipsed the hopes of an ingenious rival, who resigned the contest; nor, afterwards, did any other competitor bring his certainly ineffectual lamp into that sphere, in which so bright a luminary shone. 
Equal success, as in the case of Mr. Inge, continued to result from the powers of Dr. Darwin's genius, his frequent and intense meditation, and the avidity with which he, through life, devoted his leisure to scientific acquirement, and the investigation of disease. Ignorance and timidity, superstition, prejudice, and envy, sedulously strove to attach to his practice the terms, rash, experimental, theoretic; not considering, that without experimental theory, the restoring science could have made no progress; that neither time, nor all its accumulation of premature death, could have enlarged the circle, in which the merely practical physician condemns himself to walk. Strength of mind, fortitude unappalled, and the perpetual success which attended this great man's deviations from the beaten track, enabled him to shake those mists from his reputation, as the lion shakes to air the dewdrops on his mane.

In 1757, he married Miss Howard, of the Close of Lichfield, a blooming and lovely young lady of eighteen. A mind, which had native strength; an awakened taste for the works of imagination; ingenuous sweetness; delicacy animated by sprightliness, and sustained by fortitude, made her a capable, as well as fascinating companion, even to a man of talents so illustrious.... To her he could, 
with conficlence, commit the important task of rendering his childrens' minds a soil fit to receive, and bring to fruit, the stamina of wisdom and science.

Mrs. Darwin's own mind, by nature so well endowed, strengthened and expanded in the friendship, conversation, and confidence of so beloved, so revered a preceptor. But alas! upon her early youth, and a too delicate constitution, the frequency of her maternal situation during the first five years of her marriage, had probably a baneful effect. The potent skill, and assiduous cares of him, before whom disease daily vanished from the frame of others, could not expel it radically from that of her he loved. It was however kept at bay thirteen years.

Upon the distinguished happiness of those years, she spoke with fervour to two intimate female friends in the last week of her existence, which closed at the latier end of the stimmer of 1770 . "Do not weep for my impending fate," said the dying angel, with a smile of unaffected cheerfulness. "In the short term of my life, a great deal " of happiness has been comprised. The maladies " of my frame were peculiar; the pains in my head " and stomach, which no medicine could eradicate, "were spasmodic and violent; and required stron"ger measures to render them supportable while 
" they lasted, than my constitution could sustain " without injury. The periods of exemption from " those pains were frequently of several days dura" tion, and in my intermissions I felt no indication " of malady. Pain taught me the value of ease, " and I enjoyed it with a glow of spirit, seldom, " perhaps, felt by the habitually healthy. While " Dr. Darwin combated and assuaged my disease " from time to time, his indulgence to all $\mathrm{my}$ "wishes, his active desire to see me amused and " happy, proved incessant. His house, as you " know, has ever been the resort of people of science " and merit. If, from my husband's great and " exitensive practice, I had much less of his society " than I wished, yet the conversation of his friends, " and of my own, was ever ready to enliven the " hours of his absence. As occasional malady " made me doubly enjoy health, so did those fre" quent absences give a zest, even to delight, " when I could be indulged with his company. "My three boys have ever been docile, and " affectionate.... Children as they are, I could trust " them with important secrets, so sacred do they " hold every promise they make. They scorn " deceit, and falsehood of every kind, and have less " selfishness than generally belongs to childhood.... "Married to another man, I do not suppose I 
" could have lived a third part of those years, " which I have passed with Dr. Darwin; he has "prolonged my days, and he has blessed them."

Thus died this superior woman, in the bloom of life, sincerely regretted by all, who knew how to value her excellence, andi passionately regretted by the selected few, whom she honoured with her personal and confidential friendship. The year after his marriage, Dr. Darwin purchased an old half timbered house in the cathedral vicarage, aclding a handsome new front, with venetian windows, and commodious apartments. This front looked towards Beacon street, but had no street annoyance, being separated from it by a narrow, deep dingle, which, when the Doctor purchased the premises, was overgrown with tangled briers and knot-grass. In ancient days it was the receptacie of that water, which moated the Close in a semicircle, the other half being defended by the Minster pool. A fortunate opening, between the opposite houses and this which has been described, gives it a prospect, sufficiently extensive, of pleasant and umbrageous fields. Across' the dell, between his house and the street, Dr. Darwin flung a broad bridge of shallow steps with chinese paling, descending from his hall-door to the pavement. The tangled and hollow bottom he cleared away into 
lawny smoothness, and made a terrace on the bank, which stretched in a line, level with the floor of his apartments, planting the steep declivity with lilacs and rose-bushes; while he screened his terrace from the gaze of passengers, and the summer sun,

.6 By all that higher grew,

"Of firm and fragrant leaf. Then swiftly rose

"Acanthus, and each odorous, bushy shrub,

" To fence the verdant wall."

The last gentleman who purshased this house and its gardens, has destroyed the verdure and plantations of that dell, for the purpose of making a circular coach-road from the street to the halldoor; a sacrifice of beauty to convenience, and one of many proofs, that alteration and improvement are not always synonimous terms. To this rus in urbe, of Darwinian creation, resorted, from its early rising, a knot of philosophic friends, in frequent visitation. The Rev. Mr. Michell, many years deceased. He was skilled in astronomic science, modest and wise. The ingenious Mr. Kier, of West Bromich, then Captain Kier. Mr. Boulton, known and respected wherever mechanic philosophy is understood. Mr. Watt, the celebrated improver of the steam engine. And, above all others in Dr. Darwin's personal regard, the accomplished Dr. Small, of Birmingham, who bore the blush- 
ing honours of his talents and virtues to an untimely grave.

About the year 1765, came to Lichfield, from the neighbourhood of Reading, the young and gay philosopher, Mr. Edgeworth, a man of fortune, and recently married to a Miss Ellars of Oxfordshire. The fame of Dr. Darwin's various talents allured Mr. E. to the city they graced. Then scarcely two and twenty, and with an exterior yet more juvenile, he had mathematic science, mechanic ingenuity, and a competent portion of classical learning, with the possession of the modern languages. His address was gracefully spirited, and his conversation eloquent. He danced, he fenced, and winged his arrows with more than philosophic skill; yet did not the consciousness of these lighter endowments abate his ardour in the pursuit of knowledge.

After having established a friendship and correspondence with Dr. Darwin, Mr. Edgeworth did not return to Lichfield till the summer of the year 1770. With him, at that period, came the late Mr. Day, of Bear-hill, in Berkshire. These young men had been fellow-students in the university of Oxford. Mr. Day was also attracted by the same celebrated abilities, which, five years before, had drawn his friend into their sphere. He was 
then twenty-four, in possession of a clear estate, about twelve hundred pounds per annum.

Mr. Day looked the philosopher. Powder and fine clothes were, at that time, the appendages of gentlemen. Mr. Day wore not either. He was tall and stooped in the shoulders, full made, but not corpulent; and in his meditative and melancholy air a degree of awkwardness and dignity were blended. We found his features interesting and agreeable amidst the traces of a severe small-pox. There was a sort of weight upon the lids of his large hazle eyes; yet when he declaimed,

\section{......................" Of good and evil}

"Passion and apathy, and glory, and shame,"

very expressive were the energies gleaming from them beneath the shade of sable hair, which, Adam-like, curled about his brows. Less graceful, less amusing, less brilliant than Mr. E. but more highly imaginative, more classical, and a deeper reasoner; strict integrity, energetic friendship, openhanded bounty, sedulous and diffusive charity, greatly overbalanced, on the side of virtue, the tincture of misanthropic gloom and proud contempt of common-life society, that marked the peculiar character, which shall unfold itself on these 
pages. In succeeding years, Mr. Day published trvo noble poems, The Dying Negro, and The Devoted Legions; also Sandford and Merton, which by wise parents is put into every youthful hand. Mr. Day dedicated the third edition of the Dying. Negro to Rousseau. That dedication has every force and every grace of eloquence. The sentiments are strongly characteristic of their writer except in the philippic against American resistance just commenced when the address to Rousseau was composed. Generous indignation of the slave trade, practised without remorse in the southern colonies of North America, induced Mr. Day to refuse them all credit for the patriotic virtue of that resistance to new and unconstitutional claims which threatened their liberties.

In the course of the year 1770, Mr. Day stood for a full-length picture to Mr. Wright of Derby. A strong likeness and a dignified portrait were the result. Drawn as in the open air, the surrounding sky is tempestuous, lurid, and dark. He stands leaning his left arm against a column inscribed to Hambden. Mr. Day looks upwards, as enthusiastically meditating on the contents of a book, held in his dropped right hand. The open leaf is the oration of that virtuous patriot in the senate, against the grant of ship-money, demanded by king: 
Charles the first. A flash of lightning plays in $\mathrm{Mr}$. Day's hair, and illuminates the contents of the volume. The poetic fancy, and what were then the politics of the original, appear in the choice of subject and attitude. Dr. Darwin sat to Mr. Wright about the same period. That was a simply contemplative portrait, of the most perfect resemblance.

During the summer and autumn of that year, was found, in Dr. Darwin's circle, as Mr. Day's visiter, the late Mr. William Seward of London; yet, though a young man whose talents were considerably above the common level, he was rather a satellite than a planet in that little sphere. He, afterwards became known to the literary world as one of Dr. Johnson's habitual companions, and, in the year 1795, he published Anecdotes of Distinguished Persons; a compilation of more industry in the collection, than grace in the dress. Mr. W. Seward has not displayed in those volumes, the happy art of animating narration. Common occurrences, even in the lives of eminent people, weary attention, unless they are told with elegance and spirit. From the ardently-sought socicty of men of genius, this gentleman acquired a striking degree of wit and ingenious allusion in conversation, though it was too uniformly, and too caustically, of the sarcastic species; but every sort of fire secms 
to have craporated from the language of $\mathrm{Mr}$. W. Seward in passing through his pen.

Mr. Day and Mr. Edgeworth took the house now inhabited by Mr. Moresby, in the little green valley of Stow, that slopes from the east end of the cathedral, and forms, with its old grey tower on the banks of its lake, so lovely a landscape. That house was Mr. Day's bachelor mansion through the year 1770; that of Mr. Edgeworth, and his wife and farmily, in the ensuing year. All of this city and its vicinity, who comprehended and tasted those powers of mind which take the higher range of intellect, were delighted to mingle in such associations.

In February 1775, died Dr. Small, nor were so much talent and merit suffered to pass away,

"Without the meed of some melodious tears."

They were given in a short elegy, by his most valued friend, Dr. Darwin; which elegy is engraven on a vase in Mr. Boulton's garden, sacred to the momory of the ingenious deceased:

Ye gay, and young, who, thoughtless of your doon,

Shun the disgustful mansions of the dead,

Where Melanchoiy broods o'er many a tomb, Mouldering beneath the yew's unwholesome shade, 
If chance ye enter these sequester'd groves,

And day's bright sunshine, for a while, forego,

O leave to Folly's cheek, the laughs and loves,

And give one hour to philosophic woe!

Here, while no titled dust, no sainted bone,

No lover, weeping over beauty's bier,

No warrior, frowning in historic stone,

Extorts your praises, or requests your tear.

Cold Contemplation leans her aching head,

And as on human woe her broad eye turns,

Waves her meek hand, and sighs for science, dead,

For science, virtue, and for Small she mourns!

Epitaph on Dr. Small of Birmingham, by Mr. Day:

Beyond the rage of 'Time, or Fortune's power,

Remain, cold stone!....remain, and mark the hour:

When all the noblest gifts that Heaven e'er gave

Were destined to a dark, untimely grave.

O taught on reason's boldest wing to rise,

And catch each glimmer of the opening skies!

O gentle bosom ! O unspotted mind!

$O$ friend to truth, to virtue, and mankind,

Thy lov'd remains we trust to this pale shrine,

Secure to meet no second loss like thine!

In Mr. Day's epitaph there is some pathos, and more poetry; but it is far from being faultless. Perhaps it may be its least error, that the name of 
the bewailed is omitted, which Dr. Johnson has well observed, ought always to be involved in the verses. It must, however, be confessed, that, in this case, the noun personal was not calculated to appear with grace in verse; but that consideration, though it doubtless caused, will not justify the omission. In Dr. Darwin's Elegy, it is placed out of all possibility of ludicrous equivoque, and so accents the last line, as to produce no mean or inharmonious sound. The commendation, also, is, in the elegy, of much more dignified modesty. Praise may be allowed to glow even upon a tombstone, but should never be hyperbolic. The epitaph is too exclamatory; and to assert that no second loss, so deplorable, can be sustained, is infinitely too much for one, who, however endowed and adorned, left the world at large no written testimony of that imputed superiority. It is finely observed by the charming Prior,

"That the distinguish'd part of men,

By pencil, compass, sword, or pen,

Should, in life's visit leave their name,

In characters, which may proclaim

That they, with arclour, strove to raise

At once their art and country's praise;

And, in the working, took great care

"That all was full and round, and fair." 
The circumstances of Mr. Day's disposition,' habits, and destiny were so peculiar, as to justify digression from the principal subject of these pages.

Their author would deem it inexcusable to introduce any thing fabulous; to embellish truth by the slightest colouring of fiction, even by exaggerating singularity, or heightening what is extraordinary;.... but when realities are of a nature to interest and to amuse in a collateral branch of the memoir, the reader will not be displeased to turn from its principal personage, distinguished rather by wonderful endowment than by uncommon occurrences, while the picture of his friend's more eventful story passes before their eyes.

Mr. Day's father died during his infancy, and left him an estate of twelve hundred pounds per annum.

Soon after his mother married a gentleman of the name of Philips. The author of this narrative has often heard $\mathrm{Mr}$. Day describe him as one of those common characters, who seek to supply their inherent want of consequence, by a busy, teizing interference in circumstances, with which they have no real concern.

Mrs. Philips, jointured with three hundred pounds a year out of her son's estate, was left his sole guardian, or united with another person in the trust, whom she infiuenced. Herself, influenced 
by such a husband, often rendered uncomfortable the domestic situation of a high-spirited youth of genius. We may well suppose he impatiently brooked the preceptive impertinence, and troublesome authority of a man whom he despised, and who had no claim upon his obedience, though he considered it as a duty to pay some outward respect to the husband of his mother.

She frequently repined at the narrowness of her jointure, and still oftener expressed solicitude lest Mr. Philips, who had no fortune of his own, should lose in the decline of life, by losing her, all comfortable subsistence. It was Mr. Day's first act on coming of age, and into possession of his estate, to augment his mother's jointure to four hundred, and to settle it upon Mr. Philips during his life. This bounty to a man who had needlessly mortified and embittered so many years of his own infancy and youth, evinced a very elevated mind. That mind also had been wounded by the caprice of a young lady, who "claimed the triumph of a lettered heart," without knowing how to value and retain her prize. Before her fickleness became indisputable, he wrote the following beautiful elegy, 
Yet once again in yonder myrtle bowers,

Whence rose-lipp'd zeplyrs, hovering shed perfume,

I weave the painted radiance of the flowers, And press coy Nature in her days of bloom.

Shall she, benignant, to the wondering eyes

Of the lone hermit all her charms unfold?

Or, gemm'd with dew, bid her gay florets rise

To grace the rustic master of the fold?

Shall these possess her bright, her fragant store,

These snatch the wreath, by plastic Nature wove,

Nor wanton summer yield one garland more

To grace the bosom of the nymph I love!

For she shall come; with her each sister grace,

With her the kindred powers of harmony,

The deep recesses of the grove shall trace,

And hang with flowers each consecrated tree.

Blithe Fancy too shall spread her glittering plumes,

She loves the white cliffs of Britannia's isle,

She loves the spot where infant Genius blooms,

She lores the spot, where peace and freedom smile,

Unless her aid the mimic queen bestow,

In vain fresh garlands the low vales adorn;

In rain with brighter tints the florets glow,

Or dewdrops sparkle on the brow of morn.

Opes not one blossom to the spicy gale,

'Throws not one elm its moss-wreath'd branches wide,

Wanders no rill through the luxuriant vale,

Or, glist'ning, rushes down the mountain side, 
But thither, with the morning's earliest ray,

Fancy has wing'd her ever-mazy fight,

To hymn wild carols to returning day,

And catch the fairest beams of orient light.

Proud of the theft she mounts her lucid car,

$\mathrm{Hcr}$ car the rainbow's painted arch supplies;

Her swift wing'd steeds unnumber'd loves prepare,

And countless zephyrs waft her through the skies.

There while her bright wheels pause in cloudless air,

She waves the magic sceptre of command,

And all her flattering visions, wild as fair,

Start into life beneath the potent wand.

Here, proudly nodding o'er the vale below,

High rocks of pearl reflect the morning ray,

Whenee gushing streams of azure nectar flow,

And tinge the trickling herbage on their way.

These, cull'd from every mountain, every plain,

Perennial flowers the ambient air perfume,

Far off stern Boreas holds his drear domain,

Nor chains the streams, nor blights the sacred bloom.

Through all the year, in copse and tangled dale,

Lone Philomel her song to Venus pours,

What time pale Evening spreads the dewy veil,

What time the red Morn blushes on the shores.

Illusive visions! O, not herc,...not here,

Does Spring etcrnal hold her placid reign,

Already Boreas chills the altering year,

And blasts the purple daughters of the plain. 
So fade my promis'd joys !...fair scenes of bliss,

Ideal scenes, too long believ'd in vain,

Plung'd down and swallow'd deep in Time's abyss !...

So veering Chance, and ruthless fates ordain.

Thee, Laura, thee, by fount, or mazy stream, Or thicket rude, unpress'd by human feet, I sigh, unheeded, to the moon's pale beam ;

Thee, Laura, thee, the echoing hills repeat.

Oh! long of billows wild, and winds the sport, Seize, seize the safe asylum that remains! Here Truth, Love, Freedom, Innnocence resort, And offer long oblivion to thy pains.

When panting, gasping, breathless, on the strand The shipwreck'd mariner reclines his breast, Say, shall he scorn the hospitable liand, That points to safety, liberty, and rest?

But thou, too soon forgetful of past woe, Again would'st tempt the winds, and treacherous sea; $\mathrm{Al}$ ! shall the raging blast forget to blow, Shall cvery wintry storm be hush'd for thee?

Not so! I dread the elemental war, Too soon, too soon the calm, deceitful, flies;

I hear the blast come whistling from afar, I see the tempest gathering in the skies.

Yet let the tempest roar !...love scorns all harms,

I plunge amid the storm, resolved to save;

This hour, at least, I clasp thee in my arms,

The next let ruin join us in the grave. 
The above verses imply some perfidy, or disappointment experienced by the lady to whom they are addressed. She probably accepted Mr. Day's addresses in resentment, and afterwards found she had not a heart to give him. This is no uncommon case; and it is surely better to recede, even at the church-porch, than to plight at its altar the vow of unexisting love, which no effort of the will can implant in the bosom. It has been observed, that marriage is often the grave of love, but scarcely ever its cradle ; and what hope of happiness, what hope of a blessing on nuptials, which commence with perjury!

Even at that period, "when youth, elate and gay, steps into life," Mr. Day was a rigid moralist, who proudly imposed on himself cold abstinence, even from the most innocent pleasures; nor would he allow an action to be virtuous, which was performed upon any hope of reward, here, or hereafter. This severity of principle, more abstract and specious, than natural or useful, rendered Mir. Daysceptical towards revealed religion, though by no means a confirmed deist. Most unlike Doctor Johnson in those doubts, he resembied him in want of sympathy with such miseries as spring from refinement and the softer affections; resembled him akso, in true compassion for the sufferings of cold 
and hunger. To the power of relieving them he nobly sacrificed all the parade of life, and all the pleasures of luxury. For that mass of human character which constitutes polished society, he avowed a sovereign contempt; above all things he expressed aversion to the modern plans of female education, attributing to their infuence the fickleness which had stung him. He thought it, however, his duty to marry; nursed systematic ideas of the force of philosophic tuition to produce future virtue, and loved to mould the infant and youthful mind.

Ever despicable in Mr. Day's estimation were the distinctions of birth, and the advantages of wealth ; and he had learnt to look back with resentment to the allurements of the Graces. He resolved, if possible, that his wife should have a taste for literature and science, for moral and patriotic philosophy. So might she be his companion in that retirement, to which he had destined himself; and assist him in forming the minds of his children to stubborn virtue and high exertion. He resolved also, that she should be simple as a mountain girl, in her dress, her diet, and her manners; fearless and intrepid as the Spartan wives and Roman heroines.... There was no finding such a creauure ready made; philosophical romance could not 
hope it. He must mould some infant into the being his fancy had imaged.

With the late Mr. Bicknel, then a barrister, in considerable practice, and of taintless reputation, and several years older than himself, $\mathrm{Mr}$. Day lived on terms of intimate friendship. Credentials were procured of Mr. Day's moral probity, and with them, on his coming of age, these two friends journied to Shrewsbury, to explore the hospital in that town for foundling girls. From the little train, Mr. Day, in the presence of $\mathrm{Mr}$. Bicknel, selected two of twelve years each; both beautiful; one fair, with flaxen locks, and light eyes; her he called Lucretia. The other, a clear, auburn brunette, with darker eyes, more glowing bloom, and chesnut tresses, he named Sabrina.

These girls were obtained on written conditions, for the performance of which Mr. Bicknel was guarantee. They were to this effect; that Mr. Day should, within the twelvemonth after taking them, resign one into the protection of some reputable tradeswoman, giving one hundred pounds to bind her apprentice; maintaining her, if she behaved well, till'she married, or began business for herself. Upon either of these events, he promised to advance four hundred more. He avowed his intention of educating the girl he should retain, with 
a view to making her his future wife; solemnly engaged never to violate her innocence; and if he should renounce his plan, to maintain her decently in some creditable family till she married, when he promised five hundred pounds as her wedding portion.

Mr. Day went instantly into France with these girls; not taking an English servant, that they might receive no ideas, except those which himself might choose to impart.

They teized and perplexed him ; they quarrelled, and fought incessantiy; they sickened of the small-pox; they chained him to their bed-side by crying, and screaming if they were erer left a moment with any person who could not speak to them in English. He was obliged to sit up with them many nights; to perform for them the lowest offices of assistance.

They lost no beauty by their disease. Soon after they had recovered, crossing the Rhone with. his wards in a tempestuous day, the boat overset. Being an excellent swimmer he saved them both, though with difficulty and danger to himself.

Mr. Day came back to Fingland in eight months, heartily glad to separate the little squabblers. Sabrina was become the favourite. He placed the fair Lucretia with a chamber milliner. She behaved 
well, and became the wife of a respectable linendraper in London. On his return to his native country, he intrusted Sabrina to the care of Mr. Bicknel's mother, with whom she resided some months in a country village, while he settled his affairs at his own mansion-house, from which he promised not to remove his mother.

It has been said before, that the fame of Dr. Darwin's talents allured Mr. Day to Lichfield. Thither he led, in the spring of the year 1770 , the beauteous Sabrina, then thirteen years old, and taking a twelve month's possession of the pleasant mansion in Stowe Vallcy, resumed his preparations for implanting in her young mind the characteristic rirtues of Arria, Portia, and Cornelia. His experiments had not the success he wished and expected. Her spirit could not be armed against the dread of pain, and the appearance of danger. When he dropped meltcd sealing-wax upon her arms she did not cndurc it heroically, nor when he fired pistols at her peticontes, which she believed to be charged with balls, could she help starting aside, or suppress her screams.

When he tried her fidelity in secret-keeping; by telling her of well-invented dangers to himself, in which greater danger would result from its being discovered that he vas avare of them, he once or 
twice detected her having imparted them to the servants, and to her play-fellows.

She betrayed an averseness to the study of books, and of the rudiments of science, which gave little promise of ability, that should, one day, be responsible for the education of youths, who were to emulate the Gracchi.

Mr. Day persisted in these experiments, and sustained their continual disappointment during a year's residence in the vicinity of Lichfield. The difficulty seemed to lie in giving her motive to exertion, self-denial, and heroism. It was against his plan to draw it from the usual sources, pecuniary reward, luxury, ambition, or vanity. His watchful cares had precluded all knowledge of the value of money, the reputation of beauty, and its concomitant desire of ornamented dress. The ony inducement, therefore, which this lovely artless girl could have to combat and subdue the natural preference, in youth so blossoming, of ease to pain, of vacant sport to the labour of thinking, was the desire of pleasing her protector, though she knew not how, or why he became such. In that desire, fear had greatly the ascendant of affection, and fear is a cold and indolent feeling.

Thus, after a series of fruitless trials, Mr. Day renounced all hope of moulding Sabrina into the 6 
being his imagination had formed; and ceasing to behold her as his future wife, he placed her at a boarding school in Sutton-Coldfield, Warwickshire. His trust in the porver of education faltered; his aversion to modern elegance subsided. From the time he first lived in the Vale of Stowe, he had daily conversed with the beautiful Miss Honora Sneyd of Lichfield. Without having received a Spartan education, she united a disinterested desire to please, fortitude of spirit, native strength of intelect, literary and scientific taste, to unswerving truth, and to all the graces. She was the very Honora Sneyd, for whom the gallant and unfortunate Major Andre's inextinguishable passion is on poetic, as his military fame and hapless destiny are on patriot, record. Parental authority having dissolved the juvenile engagements of this distinguished youth and maid, Mr. Day offered to Honora his philosophic hand. She admired his talents; she revered his virtues; she tried to school her heart into softer sentiments in his favour. She did not succeed in that attempt, and ingenuously told him so. Her sister, Miss Elizabeth Sneyd, one year younger than herself, was very pretty, very sprightly, very artless, and very engaging, though countless degrees inferior to the endowed! 
and adorned Honora. To her the yet love-luckless sage transferred the heart, which Honora had with sighs resigned. Elizabeth told Mr. Day she could have loved him, if he had acquired the manners of the world, instead of those austere singularities of air, habit, and address.

He began to impute to them the fickleness of his first love; the involuntary iciness of the charming Honora, as well as that for which her sister accounted. He told Elizabeth, that, for her sake, he would renounce his prejuclices to external refinements, and try to acquire them. He would go to Paris for a year, and commit himself to dancing and fencing masters. He did so; stood daily an hour or two in frames, to screw back his shoulders, and point his feet; he practised the military gait, the fashionable bow, minuets, and cotillions; but it was too late; habits, so long fixed, could no more than partially be overcome. 'The endeavour, made at intervals, and by visible effort, was more really ungraceful than the natural stoop, and unfashionable air. The studied bow on entrance, the suddenly recollected assumption of attitude, prompted the risible instead of the admiring: sensation; neither was the showy dress, in which he came back to his fair one, a jot more becoming. 
Poor Elizabeth reproached her reluctant but insuppressive ingratitude, upon which all this labour, these sacrifices had been wasted. She confessed, that Thomas Day, blackguard, as he used jestingly to style himself, less displeased her eye than Thomas Day, fine gentleman.

Thus again disappointed, he resumed his accustomed plainness of garb, and neglect of his person, and went again upon the continent for another year, with pursuits of higher aim, more congcnial to his talents and former principles. Returning to England in the year 1773 , he saw, that spring; Miss Honora Sneyd united to his friend Mr. Edgeworth, who was become a wiclower; and, in the year 1780, he learned that his second love of that name, Miss Elizabeth Sneyd was also; after the death of Honora married to Mr. Edgeworth.

It was singular that Mr. Day should thus, in the course of seven years, find himself doubly rivalied by his most intimate friend; but his own previously renounced pursuit of those beautiful young women, left him without either cause or sensations of resentment on their account.

From the year 1773 this hitherto love-renounced philosopher resided chiefy in London, and amict 
the small and select circle which he frequented there, often met the pretty and elegant Miss Esther Mills of Derbyshire, who, with modem acquirements, and amongst modish luxuries, suited to her large fortune, had cultivated her understanding by books and her virtues by benevolence. The again unpolished stoic had every charm in her eyes,

"She saw Othello's visage in his mind."

But from indignant recollection of hopes so repeatedly baffled, Mr. Day looked with distrust on female attention of however flattering semblance; nor was it till after years of her modest, yet tender devotion to his talents and merit, that he deigned to ask Miss Mills, if she could, for his sake, resign all that the world calls pleasures; all its luxuries, all its ostentation. If, with him, she could resolve to employ, after the ordinary comforts of life were supplied, the surplus of her affluent fortune in clothing the naked, and feeding the hungry ; retire with him into the country, and shun, through remaining existence, the infectious taint of human socicty.

Mr. Day's constitutional faule, like poor Cowper's, seemed that of looking with severe and disgusted eyes upon those venial errors in his species which are mutualy tolerated by maknd. This 
stain of misanthropy was extremely deepened by his commerce with the world, restrained as that commerce had ever been. Satiric, jealous, and discerning; it was not easy to deceive him, yet in a few instances, he was deceived by the appearance of virtues congenial to his own :

" For neither man, nor angel can discern

"Hypocrisy, the only evil that walks

" Invisible, except to God alone."

To proposals so formidable, so sure to be rejected by a heart less than infinitely attached, Miss Mills gladly assented; but something more remained. Mr. Day insisted, that her whole fortune should be settled upon herself, totally out of his present or future controul; that if she grew tired of a system of life so likely to weary a woman of the world, she might return to that world any hour she chose, fully empowered to resume its habits, and its pleasures.

They married, and retired into the country about the year 1780, according to the best recollection of the author of these memoirs. No carriage; no appointed servant about Mrs. Day's own person, no luxury of any sort. Music, in which she was a distinguished proficient, was deemed trivial. 
She banished her harpsichord and music-books. Frequent experiments upon her temper, and her attachment, were made by him, whom she lived but to obey and love. Over these she often wept, but never repined. No wife, bound in the strictest fetters, as to the incapacity of claiming separate maintenance, ever made more absolute sacrifices to the most imperious husband, than did this lady, whose independence had been secured, and of whom nothing was demanded as a duty.

Thus Mr. Day found, at last, amid the very class he dreaded, that of fashionable women, a heart whose passion for him supplied all the requisites of his high-toned expectations.

Some eight or ten years after his marriage, the life of this singular being became, in its meridian, a victim to one of his uncommon systems. He thought highly of the gratitude, generosity, and sensibility of horses; and that whenever they were disobedient, unruly, or vicious, it was owing to previous ill usage from men. He had reared, fed, and tamed a favourite foal. When it was time it should become serviceable, disdaining to employ a horse breaker, he would use it to the bit and the burden himself. He was not a good horseman. The animal disliking his new situation, heeded not the soothing voice to which he had been accus- 
tomed. He plunged, threw his master, and then, with his heels, struck him on the head an instantly fatal blow It was said that Mrs. Day never afterwards saw the sun; that she lay in bed, into the curtains of which no light was admitted during: the day, and only rose to stray alone through her garden, when night gave her sorrows congenial gloom. She survived this adored husband two years, and then died, broken-hearted, for his loss.

Ere the principal subject of this biographic tract is resumed, the reader will not be sorry to learn the future destiny of Sabrina. She remained at school three years; gained the estecm of her insructress; grew feminine, elegant, and amiable. This young woman proved one of many instances that those modes of education, which have been sanctioned by long experience, are seldom abandoned to advantage by ingenious system-mongers.

When Sabrina left school, Mr. Day allowed her fifty pounds annually. She boarded some years near Birmingham, and afterwards at Newport, in Shropshire. Wherever she resided, wherever she paid visits, she secured to herself friends. Beau* tiful and admired, she passed the dangerous interval between sixteen and twenty-five, without one reflection upan her conduct, one stain upon her discretion. Often the gुuest of Dr. Darwin, and 
other of her friends in Lichfield, esteem and afiection formed the tribute to her virtues.

Mr. Day corresponded with her parentally, but seldom saw her, and never without witnesses. Two years after his marriage, and in her twentysixth year, his friend, Mr. Bicknel, proposed himself; that very Mr. Bicknel, who went with Mr. Day to the Foundling Hospital at Shrewsbury, and by whose suretyship for his upright intentions the governors of that charity permitted Mr. Day to take from thence that beanteous girl, and the young Lucretia.

Mr. Bicknel, high in practice as a barrister, was generally thought an advantageous match for Sabrina. More from prudential, than impassioned impulse, did she accept his addresses, yet becane one of the most affectionate, as well as the best of wives. When Mr. Day's consent was asked by his protegee, he gave it in these mngracious words: "I do not refuse my consent to your marrying" Mr. Bicknel; but remember you have not asked my advice." He gave her the promised dower, five hundred pounds.

Mr. Bicknel, without patrimonial fortune, and living up to his professional income, did not save money. His beloved wife brought him two boys. When the eldest was about fire years old, their 
father was seized with a paralytic stroke, which, in a few weeks, became fatal His charming widow had no means of independent support for herself and infants. Mr. Day said he would allow her thirty pounds annually, to assist the efforts which he expected she would make for the maintenance of herself and children. To have been more bounteous must surely have been in his heart, but it was not in his system. Through the benevolent exertions of Mr. Harding, Solicitor General to the Queen, the sum of eight hundred pounds was raised among the gentlemen of the bar for Mrs. Bicknel and her sons; the interest to be the mother's during her life, and the principal, at her decease, to be divided between her children.

That excellent woman has lived many ycars, and yet lives with the good Dr. Burney of Greenwich, as his housekceper, and assistant in the cares of his academy. She is treated by him, and his friends, with every mark of esteem and respect due to a gentlewoman, and one whose virtues entitle her to universal approbation. Her name was not in Mrr. Day's will, but Mrs. Day continued the allowance he had made her, and bequeathed its continuance from her orm fortune during Mrs. Bicknel's life. Mr. and Mrs. Day left no child. 
Mr. Edgeworth, having also lost his third wife, Elizabeth, is now the husband of a fourth, a daughter of the reverend Dr. Beaufort of Ireland. He had four children by his first; a son, who of late years died in America; Miss Edgerworth, the celebrated writer of Stories for Children, and Moral Tales for Young People, \&c.; Miss Anna, married to the ingenious Dr. Beddoes of Bristol; and Miss Emmeline, married to $\mathrm{Mr}$. King, surgeon of the same place. Honora left him an infant girl and boy, when she died in the year 1780. The former inherited her mother's name, her beauty, and her malady, and clied of consumption at sixteen. The amiable son yet lives, with fine talents, but infirm. health. By his third wife, Elizabeth, he has several children; and by the present, two or three. From Mr. Edgeworth's large family elaborate systems of infantile education have próceeded: of them the author of these memoirs cannot speak, as she has never seen them. Other compositions, which are said to be humorous and brilliant, are from the same source. 


\section{CHAP. II}

IT is now perhaps more than time to resume the recollected circumstances of Dr. Darwin's life.

After Dr. Small and Mr. Michell vanished from the earth, and Mr. Day and Mr. Edgeworth, in the year 1772, left the Darwinian sphere, the present sir Brooke Boothby became an occasional inhabitant of Lichfield; sought, on every possibility, the conversation of Dr. Darwin, and obtained his lasting friendship. Sir Brooke had not less poetic fancy than Mr. Day, and even more external elegance than Mr. Edgeworth possessed when he won Honora's heart; elegance, which time, its general foe, has to this hour but little tarnished in the frame of sir Brooke Bonthby.

A votary to botanic science, a deep reasoner, and a clear-sighted politician, is sir Brooke Booth. by, as his convincing refutation of that splendid, dazzling, and misleading sophistry, Burke on the 
French Revolution, has proved. Ever to be lamented is it, that national pride, and jealousy, made our efficient senate, and a large majority of people in these kingdoms, unable to discern the fallacy which sir Brooke's answer unveiled. Fallacy, which has eventually overthrown the balance of power in Europe; built up by the strong cement of opposition, the Republic's menacing and commanding tower, and wasted in combat with the phantom, Jacobinism, the nerves and sinews of defence against the time when real danger may assault Great Britain.

About the period at which sir Brooke first sought Dr. Darwin, sought him, also, Mr. Munclay of Marketon, whose exertions, as a public magistrate, have through life been most benignly sedulous and wise; with whom

"The fair ey'd Virtues in retirement dwell ;"

and whose 'Needwood Forest' is one of the most beautiful local poems that has been written. Its landscapes vivid and appropriate; its episodes sweet and interesting; its machinery well fancied and nriginal; its numbers spirited, correct, and harmonious; while an infusion of sweet and gentle morality pervades the whole, and renders it dear to 
the heart as to the eye and ear.' Great is the loss to poetic literature, that, of this delightful composition, only a few copies were privately printed, for presents to the author's friends and acquaintance; that he cannot overcome his reluctance to expose it to the danger of illiberal criticism from some of the self-elected censors in every periodical publication. The public imagines, that, on each subjcet discussed in a review and magazine, it obtains the joint opinion of a set of learned men, employed to appreciate the value of publications.... That in every such work many writers are engaged is true; yet is it no less true that in each seperate tract the opinion is merely individual on every various theme. One person is appointed to review the medical, another the chirurgical, another the clerical, another the historical, another the philosophical articles, another the ethics in prose, and another the poetry; and each criticises singly, and unassisted, in his appointed range

The most distinguished of Dr. Darwin's scientific friends, who visited him from a distance when he lived in Lichfield, have now been enumerated.

He once thought inoculation for the measles might, as in the small-pox, materially soften the 
disease; and after the patriotic example of lady Mary Wortley Montague, he made the trial in his own family, upon his youngest son, Robert, now Dr. Darwin of Shrewsbury, and upon an infant daughter, who died within her first year. Each had, in consequence, the disease so severely, as to repel, in their father's mind, all future desire of repeating the experiment.

In the year 1768, Dr. Darwin met with an accident of irretrievable injury in the human frame. His propensity to mechanics had unfortunately led him to construet a very singular carriage. It was a platform, with a seat fixed upon a very high pair of wheels, and supported in the front, upon the back of the horse, by means of a kind of proboscis, which, forming an arch, reached over the hind quarters of the horse, and passed through a ring, placed on an upright piece of iron, which worked in a socket, fixed in the saddle. The horse could thus move from one side of the road to the other, quartering, as it is called, at the will of the driver, whose constant attention was necessarily cmployed to regulate a piece of machinery contrived, but not weli contrived for that purpose. From this whimsical carriage the Doctor was several times thrown, and the last time he used it, had the misfortune, from a similar accidcnt, to break the patella of his 
right knce, which caused, as it always must cause, an incurable weakness in the fractured part, and a lameness, not very discemible indeed, when walking on even ground.

It is remarkable, that this uncommon accident happened to three of the inhabitants of Lichfield in the course of one year; first to the author of these memoirs in the prime of her youth; next, to Dr. Darwin; and, lastly, to the late Mr. Levett, a gentleman of wealth and consequence in the town. No such misfortune was previously remembered in that city, nor has it once recurred through all the years which have since elapsed.

Dr. Darwin was happy in the talents, docility, and obedience, of his three sons. An high degree of stammering retarded and cmbarrassed his utterance. 'The eldest boy, Charles, had contracted the propensity. With that wisclom, which marked the Doctor's observations on the habits of life; with that decision of conduct, which always instantly followed the conviction of his mind, he sent Charles abroad ; at once to break the force of habit, formed on the contagion of daily example, and from a belief, that in the pronunciation of a foreign language, hesitation would be less likcly to recur, than in rpeaking those words and sentences, in which he had been accustoned to hesitate. About his twclfih 
year he was committed to the care of the scientific, the learned, the modest, and worthy Mr. Dickinson, now rector of Blimel, in Shropshire:

That the purpose of the experiment might not bè frustrated, Dr. Darwin impressed that good man's mind with the necessity of not permitting his pupil to converse in English; nor ever to hear it uttered after he could at all comprehend the French language. Charles Darwin returned to England after a two year's residence on the continent, completely cured of stammering; with which he was not afterwards troubled; but his utterance was from that time, somewhat thick and hurried.

Since these memoirs commenced, an odd anecdote of Dr. Darwin's early residence at Lichfield was narrated to a friend of the author by a gentleman, who was of the party in which it happened. Mr. Sneyd, then of Bishton, and a few more gentlemen of Staffordshire, prevailed upon the Doctor to join them in an expedition by water, from Burton to Nottingham, and on to Newark. They had cold provision on board, and plenty of wine. It was midsummer; the day ardent and sultry. The noontide meal had been made, and the glass gone gaily round. It was one of those few instances, in which the medical votary of the Naiads transgressed his general and strict sobriety. If not absolutely 
intoxicated, his spirits were in a high state of vinous exhilaration. On the boat approaching Nottingham, within the distance of a few fields, he surprised his companions by stepping, without any previous notice, from the boat into the middle of the river, and swimming to shore. They saw him get upon the bank, and walk coolly over the meadows toward the town : they called to him in vain, he did not once turn his head

Anxious lest he should take a dangerous cold by remaining in his wet clothes, and uncertain whether or not he intended to desert the party, they rowed instantly to the town, at which they had not designed to have touched, and went in search of their river-god.

In passing through the market-place, they saw him standing upon a tub, encircled by a crowd of people, and resisting the entreaties of an apothecary of the place, one of his oid acquaintance, who was importuning him to go to his house, and accept of other raiment till his own could be dried.

The party, on pressing through the crowd were surprised to hear him speaking without any degree of his usual stammer.

"Have I not told you, my friend, that I had " drank a considerable quantity of wine before I "committed myself to the river. You know my 
"general sobriety; and, as a professional man, you " ought to know, that the unusual existence of " internal stimulus, would, in its effects upon the "system, countcract the external cold and mois"ture."

Then, perceiving his companions near him, he nodded, smiled, and waved his hand, as enjoining them silence, thus without hesitation, addressing the populace:

"Ye men of Nottingham, listen to me. You "are ingenious and industrious mechanics. By "your industry life's comforts are procured for " yourselves and families. If you lose your health, " the power of being industrious will forsake you. "That you know; but you may not know, that to "breathe fresh and changed air constantly, is not "less necessary to preserve health, than sobrieiy " itself. Air becomes unwholesome in a few hours " if the windows are shut. Open those of your "sleeping-rooms whenever you quit them to go to "your workshops. Keep the windorvs of your "workshops open whenever the weather is not in" supportably cold. I have no interest in giving "you this adrice. Remember what I, your coun"tryman, and a physician, tell you. If you would " not bring infection and disease upon yourselves, " and to your wives and litile ones, change the sir 
"you breathe, change it many times in a day, by "opening your windows."

So saying, he stept down from the tub, and returning with his party to their boat, they pursued their voyage:

Dr. Johnson was several times at Lichfield, on visits to Mrs. Lucy Porter his daughter-in-law, while Dr. Darwin was one of its inhabitants. They had one or two interviews, but never afterwards sought each other. Mutual and strong dislike subsisted between them. It is curious that in Dr. Johnson's various letters to Mrs. Thrale, now Mrs. Piozzi, published by that lady after his death, many of them, at different periods, dated from Lichfield, the name of Darwin cannot be found; nor indeed, that of any of the ingenious and lettered people who lived there; while of its mere commonlife characters there is frequent mention, with many hints of Lichfield's intellectual barrenness, while it could boast a Darwin, and other men of clașsical learning, poetic talents, and liberal information. Of that number was the Rev. Thomas Seward Canon-Residentiary of its Cathedral; known to the lettered world as critical editor of Beaumont and Fletcher's Plays, in concert with Mr. Simpson. Their edition came out in the year 1750. By people of literary taste and judgment, it is allowed. 
to be the best commentary on those dramatic poets which has appeared; and that from the lucid ability of Mr. Seward's readings and notes. Strange, that dramas, so entirely of the Shaksperian school, in the business and interest of their plots; in the strength and variety of their characters; and which, in their sentimeints and language, possess so much of Shakspeare's fire, should be coldly and stupidly neglected in the present day, which has not yet forgotten to proclaim the Bard of Avon to be, what he surely is, the first poet the world has produced. Shakspeare has had few more spirited eulogists than Mr. Seward, in the following lines, written about the year 1740, and published, together with other little poems of his, in Dodsley's Miscellany:

Great Homer's birth seren rival cities claim

Too mighty such monopoly of fame!

Yet not to birtli alone did Homer owe

His wond'rous worth, what Egypt could bestow,

With all the schools of Greece, and Asia join'd,

Enlarg'd th' immense expansion of his mind.

Nor yet unrivall'd the Meonian strain,

The British Eagle and the Mantuan Swan

Tower equal heights; but happier, Stratford, thou

With uncontested laurels deck thy brow!

Thy Bard was thine unschool'd, and from thee brought

More than all Egypt, Greece, or Asia taught; 
Not Homer's self such peerless honours won,

The Greek has rivals, but thy Shakspeare none!

In the later editions of Dodsley's Miscellany, the word Swan, in the fourth couplet, is most absurdly changed to swain, because it chimed more completely to the foregoing rhyme, strain, at the expense of every thing like sense and accuracy in the appositc terms; at the expense of making a bird and a man tly equal heights ere balloons were dreamed of. Mr. Seward was often heard to laugh at this instance of editorial presumption and stupidity*.

Another of the Lichfield literati, overlooked by the arrogant Johnson, was the Reverend ArchDeacon Vyse, the amiable the excellent father of the present ingenious Dr. Vyse of Lambeth, and his gallant brother General Vyse. Mr. Vyse was not only a man of learning, but of Prioric talents in the metrical impromptu. Gentle reader, behold an instance! and if thou hatest not rhyme, as dores many an ungentle reacler, "worse than toad or asp," thou wilt not think it intrusive.

Mrs. Vyse, herself a beautiful woman, had a fair friend whose name was Charlotte Lynes. At a convivial meeting of Lichfield gentlemen, most

* This gentleman was father of the writer of these memroirs. 
of whom could make agreeable verses, it was proposed that every person in company should give a ballad or epigram on the lady whose health he drank. Mr. Vyse toasted Miss Lynes, and, taking out his pencil, wrote the following stanzas cxtempore:

Shall Pope sing his flames

With quality dames,

And duchesses toast when he dines;

Shall Swift verses compose

On the Girl at the Rose,

While unsung is my fair Charlotte Lynes?

O! were Phœbus my friend,

Or would Bacchus but lend

The spirit that flows from lis vines,

The lass of the mill,

Molly Mogg, and Lepell,

Should be dowdies to fair Charlotte Lynes.

Any porter may serve,

For a copy, to carve

An Alcides, with muscular chines;

But a Venus to draw,

Bright as sun ever saw,

Let him copy my fair Charlotte Lynes.

In the midst of gay sights,

And foreign delights,

For his country the banish'd man pines;

'Thus, from her when away,

Though my glances may strar,

Yet my heart is with fair Charlotte Iynes. 
It is Atropus' sport, -

With her sheers to cut short

The thread, which dame Lachesis twines;

But forbear, you curst jade,

Or cut mine, not the thead

That was 'spun for my fair Charlotte Lynes!

For quadrille when the fair

Cards and counters prepare,

They cast out the tens, eights, and nincs,

And in love 'tis my fear'

'The like fate I shall share,

Discarded by fair Charlotte Lynes.

With hearts full of rapture

Our good dean and chapter

Count over, and finger their fines;

But I'd give their estate,

Were it ten times as great,

For one kiss of my fair Charlotte Lynes.

The young pair, for a crown,

On the book laid him down,

The sacrist obsequiously joins,

Were I bishop I sware

I'd resign him my chair,

'To unite me with fair Charlotte Lynes

For my first night I'd go

To those regions of snow,

Where the sun, for six months, never shines,

- And $\mathrm{O}$ ! there should complain

He too soon came again

To disturb me with fair Charlotte Lynes! 
These verses were much read, admired, and copied. Mr. Vyse thought his fair Charlotte growing too vain in consequence, and once, when she was complimented on the subject in a large company, he said smilingly,

"Charlotte the power of song can tell,

"For 'twas the ballad made the belle."

The late Reverend William Robinson was also a choice spirit amongst those Lichfieldians, whose talents illuminated the little city at that period. Too indolent for authorism, he was, by wit and learning, fully empowered to have shone in that sphere. More of him hereafter.

These were the men whose intellectual existence passed unnoticed by Dr. Johnson in his depreciating estimate of Lichfield talents. But Johnson liked only worshippers. Arch-deacon Vyse, Mr. Seward and Mr. Robinson, paid all the respect and attention to Dr. Johnson, on these his visits to their town, due to his great abilities, his high reputation, and to whatever was estimable in his mixed character; but they were not in the herd that "paged his heels," and sunk, in servile silence, under the force of his dogmas, when their hearts and their judgments bore contrary testimony. 
Certainly, however, it was an arduous hazard to the feelings of the company to oppose, in the slightest degree, Dr. Johnson's opinions. His stentor lungs; that combination of wit, humour, and eloquence, which" could make the worse appear the better reason ;" that sarcastic contempt of his antagonist, never suppressed or even softened by the due restraints of good-breeding, were sufficient to close the lips, in his presence, of men, who could have met him in fair argument, on any ground, literary or political, moral or characteristic.

Where Dr. Johnson was, Dr. Darwin had no chance of being heard, though at least his equal in genius, his superior in science; nor indeed, from his impeded utterance, in the companyof any overbearing declaimer; and he was too intellectually great to be an humble listener to Johnson, therefore he shunned him, on having experienced what manner of man he was. The surly dictator felt the mortification and revenged it, by affecting to avow his disdain of powers too distinguished to be an object of genuine scorn.

Dr. Darwin, in his turn, was not much more just to Dr. Johnson's genius. He uniformly spoke of him in terms, which, had they been deserved, wou!d have justined Churchill's " immane Pom. poso," as an appellation of scorn; since, if his 
person was huge, and his manners pompous and violent, so were his talents vast and powerful, in a degree from which only prejudice and resentment could withhold respect.

Though Dr. Darwin's hesitation in speaking precluded his flow of colloquial eloquence, it did not impede, or at all lessen, the force of that conciser quality, wit. Of satiric wit he possessed a very peculiar species. It was neither the dead-doing. broadside of Dr. Johnson's satire, nor the aurora borealis of Gray, whose arch, yet coy and quiet fastidiousness of taste and feeling, as recorded by Mason, glanced bright and cold through his conversation, while it seemed difficult to define its nature; and while its effects were rather perceived than felt, exciting surprise more than mirth, and never awakening the pained sense of being the object of its ridicule. That unique in humorous verse, the Long Story is a complete and bcautiful specimen of Gray's singular vein.

Darwinian wit is not more easy to be defined; instances will best convey an idea of its character to those who never conversed with its possessor. To give such as are recollected at this moment, it will be necessary to recall Mr. Robinson, already mentioned, as a choice spirit of Lichfield. His perpetual stream of frolic raillery was of a species so singular 
as to have exclusively obtained, wherever he was known, the title of rector, "The Rector," as if there were no other. The odd excursions of his fancy were enriched by an exhaustless siore of classic, historic, and theological learning, grotesquely applied to the passing subjects of conversation, and that with unrivaled ease and happiness. Itis to be regretted that no records remain of talents so uncommon, cxccpt in the fading traces of con. temporary recollection, which time and mortality obiiterate so soon.... Trequently cluring his youth and midale life in the fashionable circles of Bath, London, and the summer public places, the whimsical sallies of the Rector's sportive imagination, which were never coarse or low, common place or ill-natured, had considerable publicity and eclat. They were like the lambent lightning of a calm summer evening, brilliant, but notdangerous. The sweetness of his temper was the security of every man's self-love; and, while his humorous gaiety "set the table in a roar," the company laughed at their case.

But then good-nature was the only curb his wit could endure. Without the slightest taint of inficility, Robinson could not resist the temptation of launching it even at the most serious objects and themes. 
One evening, when he and Dr. Darwin were in company together, the Rector had, as usual, thrown the bridle upon the neck of his fancy, and it was scampering over the church-yard, and into the chancel, when the Doctor exclaimed...." Ex" cellent! Mr. Robinson is not only a clever fellow, "but a d.......d clever fellow."

Soon after the subject of common swearing was introduced, Mr. R. made a mock eulogium upon its power to animate dullness and to season wit.... Dr. Darwin observed, "Christ says, Swear not at " all. St. Paul tells us we may swear occasionally. "Mr. Robinson advises us to swear incessantly. "Let us compromise between these counsellors, " and swear by non-en-ti-ties. I will swear by " my im-pu-dence, and Mr. Robinson by his mo" dest-y."

That gentleman, whose wit, where it met no equal resistance, kept an untired and sparkling course, could seldom recover its track when the jest and the laugh were with his adversary. So often was it thus when Dr. Darwin and he met, that Mr. $R$. rather shunned than sought the rencounter. It was curious, that he, who met indulgence from his clerical and pious brethren for those frolic emanations, wont to play upon the themes his heart revered, should so often find himself reproved, with 
cutting raillery, for the practice, by one not famous for holding religous subjects in veneration.

Dr. Darwin was conversing with a brother Botanist, concerning the plant Kalmia, then just an imported stranger in our green-houses and gardens. A lady, who was present, concluding he had seen it, which in fact he had not, asked the Doctor what were the colours of the plant. He replied, "Madam, the Kalmia has precisely the colours of a seraph's wing." So fancifully did he express his want of consciousness respecting the appearance of a flower whose name and rareness were all he knew of the matter.

Dr. Darwin had a large company at tea. His servant announced a stranger lady, and gentleman. The female was a conspicuous figure, ruddy, corpulent, and tall. She held by the arm a little, meek-looking, pale, effeminate man, who from his close adherence to the side of the lady, seemed to consider himself as under her protection.

" Dr. Darwin, I seek you not as a physician, "but as a Belle Esprit. I make this husband of " mine," and she looked down with a sideglance upon the animal " treat me every summer with a tour " through one of the British counties, to explore " whatever it contains worth the attention of inge" nious people. On arriving at the several inns in 
" our route, I always search out the man of the "vicinity most distinguished for his genius and " taste, and introduce myself, that he may direct, " as the objects of our examination, whatever is " curious in nature, art or science. Lichfield will " be our headquarters during several days. Come, "Doctor, whither must we go, what must we in"vestigate to-morrow, and the next day, and the "next? here are my tablets and pencil."

"You arrire, madam, at a fortunate juncture." "To-morrow you will have an opportunity of sur" veying an annual exhibition perfectly worth your "attention. To-morrow, madam, you will go to " Tutbury bull-running."

The satiric laugh with which he stammered out the last word, more keenly pointed this sly, yet broad rebuke to the vanity and arrogance of her speech. She had been up amongst the boughs, and little expected they would break under her so suddenly, and with so little mercy. Her large features swelled, and her eyes flashed with anger....I " was recommended to a man of genius, and I find " him insolent and ill-bred."... Then, gathering up her meek and alarmed husband, whom she had loosed when she first spoke, under the shadov of her broad arm and shoulder, she strutted out of the room. 
After the departure of this curious couple, his guests told their host he had been very unmerciful. I chose, replied he; to avenge the cause of the little man, whose nothingness was so ostentatiously displayed by his lady-wife. Her vanity has had a smart emetic. If it abates the symptoms, she will have reason to thank her physician who administered without hope of a fee. 


\section{CHAP III.}

A вочт the year 1771 , commenced that great work, the Zoonomia, frrst published in 1794; the gathered wisdom of three-and-twenty years. Ingenious, beyond all precedent in its conjectures, and embracing, with giant-grasp, almost every branch of philosophic science; discovering their bearings upon each other, and those subtle, and, till then, concealed links by which they are united; and with their separate, conjunctive and collective influence upon human organization; their sometimes probable, and at others demonstrative, power, under judicious application, of restoring that regularity to the mechanism of animal life, which is compre. hended under the term health.

It cannot be denied that in the pursuit of a new and favourite system, Dr. Darwin has, in some instances, imperiousiy rejected the adverse facts which opposed his theory. His chapter on Instinct, highly ingenious as it is, affords proof of his hypothetical devotion. He there denies, at least 
by strong implication, the existence of that faculty so termed, and which God has given to his inferior family, in lieu of the rational. But this wonderfully ingenious philosopher seeks in vain to melt down in his system of imitation amongst brutes, the eternal boundaries which separate instinct and reason.

God, who has exempted the orders of brutal life from responsibility for their actions in this terrestrial sphere, gave them instinct, incapable of error, but also, beyond a certain very limited degree, incapable of improvement; incapable of all that are termed the artificial passions.

God, who made man accountable, and earthly life his state of trial, gave him the nobier faculty of reason, liable to err, but in countless degrees, more connected with volition; and, according to its different degrees of native strength, almost interminably capable of improvement.

Instinct cannot be that lower degree of reason which empowers the animal to observe, and, by will and choice, to imitate the actions, and acquire the arts of his species; since, were it so, imitation would not be confined to his own particular genus, but extend to the actions, the customs, and the arts of other animals; as men observe, and emulate, the actions, customs, and arts of the natives of other 
countries. Thus, improvement would have advanc ed amongst brutes, in proportion as it has advanced in mankind. That it has not advanced in brutal life, through countless generations, we have the testimony of all records to ascertain. Therefore is it, that the instinctive faculty must be totally different power to the rational; in as mush as it has a perfection unknown to reason, and as it has an incapacity of progression which counteracts that limited perfection, and renders it a thousand fold inferior to the expanding, aspiring, and strength. ening power of human intelligence. Between the separate nature of those faculties, insurmountable and everlasting are the barriers. Philosophy cannot throw them down; but in the attempt, as in many another,

"Vaulting Amв т тіоn doth o'erleap itself, "And falls where it would mount."

If the Creator had indeed given to brutal life that degree of reason, which Dr. Darwin allots to it, when he asserts that its various orders act from. imitation, which must be voluntary, rather than from impulse, which is resistless, the resulting mischief of clisorder and confusion amongst those classes had outweighed the aggregate good of im - 
provement. It is reasonless, will-less instinct, limited but undeviating, which alone could have preserved, as they were in the beginning, are now, and ever shall be, the numberless divisions and subdivisions of all merely animal life. As attraction is the planetary curb of the solar system, confining all orbs to their proper spheres, so is instinct the restraint, by which brutes are withheld from incroaching upon the allotted ranges and privileges of their fellow-brutes; from losing their distinct natures in imitation, blending and endless. If imitation were the source of brutal acquirements, whence the undeviating sameness of those acquirements? whence their never extended limit? Wherefore, since the ear of the feathered warbler is open to the immense variety of strains, poured from the throat of birds of other plume, whence its invariable choice of the family song? And when the female sees such numbers of different nests building around her for the reception of the callow brood, whence her inflexible attachment to the family nest?

Dr. Darwin read his chapter on Instinct to a lady, who was in the habit of breeding canary birds. She observed that the pair, which he then saw building their nest in her cage, were a male and female, who had been hatched, and reared in that very 
cage, and were not in existence when the mossy cradle was fabricated, in which they first saw light. She asked him how, upon his principle of imitation, he could account for the nest he then saw building, being constructed, even to the precise disposal of every hair and shred of wool, upon the model of that, in which the pair were born, and on which every other canary-bird's nest is constructed, where the proper materials are furnished. That of the pyefinch, added she, is of much compacter form, warmer, and more comfortable. Pull one of them to pieces for its materials; place another before these canary-birds, as a pattern, and see if they will make the slightest effort to imitate their model! No, the result of their labors will, upon instinctive, hereditary impulse, be exactly the slovenly little mansion of their race; the same with that which their parents built before themselves were hatched. The Doctor could not do away the force of that single fact, with which his system was incompatible; yet he maintained that system with philosophic sturdiness, though experience brought confutation from a thousand sources.

Mr. Fellowes, the eminent champion in our day, of true aud perfect Christianity, against the gloomy misrepresentations of the Calvinists, has not less truly than ingeniously observed, that 
" Dr. Darwin's understanding had some of the " properties of the microscope; that he looked " with singularly curious and prying eyes, into the " economy of plants and the habits of animals, and " laid open the labyrinth of nature in some of her " most elaborate processes and most subtle com" binations; that he was acquainted with more links " in the chain of second causes than had probably " been known to any individual, who went before "him; but that he dwelt so much, and so exclu" sively on second causes, that he too generally " seems to have forgotten that there is a first."

Certainly Dr. Darwin's distinguished power of disclosing the arcana of nature, enabled him to explore, and cletect, the falacy of many received and long-established opinions; but the proud consciousness that his scientific wand so often possessed the power attributed by Milton to Ithuriel's spear, betrayed him at times, into systematic error. Convinced, by deep thought and philosophic experience, that mankind received so many prejudices for truths, he looked too jealously at all its most revered and sacred axioms. Beneath the force of that jealousy he denied the power of instinct, and solved it into imitation. To have admitted, on the testimony of all impartial observation, all fair experiment, the unblenting natures of instinct and 
reason, must have involved that responsibility of man to his Creator for his actions in this his state of trial, which Dr. Darwin considered as a gloomy unfounded superstition. Unquestionably, if reason, like instinct, were incapable of warp from the power of volition, man could have no vice which might justly render him amenable to punishment in a future state; neither could he have any virtue for whose cultivation he might hope eternal reward. But, since his rational faculty is choice, not impulse, capable, at will, of refinement or degradation; whether it shall be his pole-star to virtue and piety, or his ignus fatuus to vice and irreligion, it inevitably follows that man is accountable to God for his conduct; that there is a future and retributory state.

If this brilliant and dazzling philosopher had not closed the lynx's eye of his understanding on that clear emanation from the source of intellectual as well as of planetary light, he had indeed been great and illuminated abore the sons of men. Then had he disclained to have mingled that art in his wisdom, which was sometimes found in his common-life actions, and of which he not unfrequently boasted.

That noble simplicity which disclains the varnish of disengenuous design in principal and in 
conduct, in conversation and in writing, was the desideratum of Dr. Darwin's strong and comprehensive mind. Its absence rendered his systems, which were so often luminous, at times impenetrably dark by paradox. Its absence rendered his poetic taste somewhat meretricious from his rage for ornament; chilled his heart against the ardour of devotion, and chained his mighty powers within the limits of second causes, though formed to soar to INFINITE.

If, however, the doctrines of the Zoonomia are not always infallible, it is a work which must spread the fame of its author over lands and seas, to whatever clime the sun of science has irradiated and warmed. The Zoonomia is an exhaustless repository of interesting facts, of curious experiments in natural productions, and in medical effects; a vast and complicated scheme of disquisition, incalculably important to the health and comforts of mankind, so far as they relate to objects merely terrestrial; throwing novel, useful, and beautiful light on the secrets of physiology, botanical, chemical, and aerological.

The world may consider the publication of the Zoonomia as a new era of pathologic science; the source of important advance in the power of disclosing, abating, and expelling disease. Every 
young professer of medicine, if Grod has given him comprehension, assiduity, and energy, should devote his nights and days to studying this great work. It will teach him more than the pages of Galen and Hippocrates; than schools and universities know to impart. Those instructions which, through the channel of its pages, flow to the world, enabled $\mathrm{Dr}_{\mathrm{r}}$. Robert Darwin of Shrewsbury to attain instant eminence as a physician in that country, at his first outsetting, and in the bloom of scarcely ripened youth; to continue a course of practice, which has been the blessing of Shropshire; its sphere expanding with his growing fame. That son, who joins to a large portion of his father's science and skill, all the ingenuous kindness of his mother's heart. That son, whose rising abilities and their early eclat, recompensed to Dr. Darwin a severe deprivation in the death of his eldest and darling son, Charles, of whom this memoir has already spoken. He was snatched from the world in the prime of his youth, and with the highest character at the university of Edinburgh, by a putrid fever, supposed to have been caught from dissecting, with a slightly wounded finger, a corps in a state of dan. gerously advanced putrefaction. When society became deprived of his luxuriantly blossoming talents, Mr. Charles Darwin had resently received an hono- 
rary medal from the Society of Arts and Sciences, for having discovered a criterion by which pus may be distinguished from mucus.

A few years before Dr. Darwin left Lichfield as a residence he commenced a botanical society in that city. It consisted of himself, Sir Brooke Boothby, then Mr. Boothby, and a proctor in the Cathedral jurisdiction, whose name was Jackson. Sprung from the lowest possible origin, and wholly uneducated, that man had, by the force of literary ambition and unwearied industry, obtaineci admittance into the courts of the spiritual law, a profitable share of their emoluments, and had made a tolerable proficiency in the Latin and French languages. His life, which closed at sixty, was probably shortened by lateacquired habits of ebriety. He passed through its course a would-be philosopher, a turgid and solemn coxcomb, whose morals were not the best, and who was vain of launching his pointless sneers Revealed Riligion.

Jackson admired Sir Brooke Boothby, and worshipped and aped Dr. Darwin. He became a useful drudge to each in their joint work, the translation of the Linnæn system of vegetation into English from the Latin. His illustrious coadjutors exacted of him fidelity to the sense of their author, and they corrected Jackson's inelegant English, weeding it of its pompous coarseness. 
The Doctor was probably disappointed that no recruits flocked to his botanical standard at Lichfield. The young men of the genteel classes in that city devoted themselves to professions with which natural history had no inseparable connexion. However useful, entertaining, and creditable might be its studies, they felt little clesire to deck the board of session, the pulpit, or the ensigns of war, with the Linnæn wreaths and the chemical crystalines. Thus the original triumvirate received no augmentation, yet the title was maintained. Various observations, signed Lichfield Botanical Society, were sent to the periodical publications, and it was amusing to hear sientific travellers, on their transit over Lichfield, inquiring after the state of the botanical society there.

About the year 1779, at the house of his friend, Mr. Sneyd of Belmont, whose seat in the wild and hilly part of Staffordshire Moorlands is eminent for its boldly romantic features, Dr. Darwin wrote an address to its owner, from the Naiad of that scene. Her rivulet originally took its course along the cieep bottom of cradling woods, luxuriantly clothing the steeply sloping mountains, which a rough glen, and this its brook, divided.

Mr. Sneyd caused the rough and tangled glen to be cleared and hollowed into one entire basin, 
which the brook immediately filled with the purest and most transparent water. Only a very narrow, marginal path is left on each side, between the water and those high woody mountains which shut the liquid scene from every other earthly object. This lake covers more than five acres, yet is not more than seventy yards across, at the broadest part. The length is, therefore, considerable. It gradually narrows on its flow, till suddenly, and with loud noise, it is precipitated down a craggy, dark, ling and nearly perpendicular fall of forty feet. The stream then takes its natural channel, losing itself in the sombre and pathless woods which stretch far onward.

While we walk on the brink of this liquid concave; while we listen to the roar, with which the tumbling torrent passes away; while we look up on each side, to the umbrageous eminences which leave us only themseives, the water, and the sky, we are impressed with a sense of solemn seclusion, and might fancy ourselves in the solitudes of 'Tinian or Juan-Fernandes. The trees and shrubs which, from such great elevation, impend over the flood, give it their own green tint without lessening its transparency. Glassy smooth, this lake has not a wave till within a few yards of its precipitance. But it is time to introduce Dr. Darwin's verses 
already mentioned. They were written before the existence of the Lake, and while the brook, which formed it, had the silence imputed to it by the poet.

Address of a water Nymph at Belmont, to the Owner of that place.

$\mathrm{O}$ ! Friend topeace und Virtue, ever flows

For thee my silent and unsullied stream,

Pure and untainted as thy blameless life!

Let no gay converse lead thy steps astray

To mix my chaste wave with immodest wine,

Nor with the poisonous cup, which Chemia's hand

Deals, fell enchantress, to the sons of folly!

So shall young Health thy daily walks attend,

Weave for thy hoary brow the vernal flower

Of cheerfulness, and with his nervous arm

Arrest th' inexorable scythe of 'Time.

The exortation was not disobeyed; the benediction was not fruitless. Mr. Sneyd still lives to exhilarate the spirits of his friends, and to be the blessing of his neighbourhood. The duties of a public magistrate, exerted with energy, and tempered with kindness; the hospitality of his social mansion; his pursuit of natural history, and taste for the arts, are unlessened by time, and no corporal infirmity allays their enjoyment. After a lapse of seventy years he passes several hours every day, 
in all seasons when the weather is dry, in the open air, forming for his scenes new plans of cultivation and ornament. Look at Mr. Sneyd, ye young men of fortune, and reflect upon the robust and happy consequence of youthful sobriety, of religion, morality, had a cultivated mind!

"The age of such is as a lusty winter,

"Frosty, but kindly.

In the spring of the year 1778 the children of Colonel and Mrs. Pole of Radburn, in Derbyshire, had been injured by a dangerous quantity of the cicuta, injudiciously administered to them in the hooping cough, by a physician of the neighbourhood. Mrs. Pole brought them to the house of Dr. Darwin, in Lichfield, remaining with them there a few weeks, till, by his art, the poison was expelled from their constitutions, and their health restored.

Mrs. Poie was then in full bloom of her youth and beauty. Agreeable features; the glow of health; a fascinating smile; a fine form, tall and graceful; playful sprightiness of manners; a benevolent heart, and maternal affection, in all its unwearied cares and touching tenderness, contributed to inspire Dr. Darwin's admiracion, and to secure 
his esteem. Soon after she left Lichfield, with her renovated little ones, their restorer sent to his friend, Mr. Bolton of Birmingham, the following directions for making a tea-vase, designed as a present from the Doctor to Mrs. Pole :

Friend Bolton, take these ingots fine

From rich Potosi's sparkling mine;

With your nice art a tea-vase mould, Your art, more valu'd than the gold. With orient pearl, in letter's white, Around it, "To the fairest," write; And, where proud Radburn's turrets rise,

To bright Eliza send the prize.

I'll have no bending serpents kiss

The foaming wave, and seem to hiss;

No sprawling dragons gape with ire, And snort out steam, and vomit fire;

No Naiads weep; no sphinxes stare;

No tail-hung dolphins swim in air.

Let leaves of myrtle round the rim,

With rose-buds twisting, shade the brim;

Each side let woodbine stalks descend, And form the branches as they bend; While on the foot a Cupid stands And twines the wreath with both his hands. 
Perch'd on the ri̛sing lid above,

O place a lovelorn, turtle dove,

With hanging wing, and ruffled plume,

With gasping beak, and eye of gloom.

Last, let the swelling bosses shine

With silver, white, and burnish'd fine,

Bright as the fount, whose banks beside

Narcissus gaz'd, and lov'd, and died.

Vase, when Eliza deigns to pour,

With snowy hand, thy boiling shower;

And sweetly talks, and smiles, and sips

The fragrant steam, with ruby lips,

More charms thy polish'd orb shall shew

Than Titian's glowing pencil drew;

More than his chisel soft unfurl'd,

Whose heav'n-wrought statue charms the world.

Soon after the composition of these gallant verses to Mrs. Pole, circumstances arose which gave rise to the following ode, not less beautiful, though much less gay:

Fly, gentle steeds !...o'er yon unfriendly towers Malignant stars, with baleful influence reign; Cold Beauty's frown infects the cheerless hours, And Avarice dwells in Love's polluted fane! 
Dim distant towers! whose ample roof protects All that my beating bosom holds so dear, Far shining lake! whose silver wave reflects Of Nature's fairest forms, the form most fair ;

Groves, where at noon the sleeping Beauty lies;

Lawns, where at eve her graceful footsteps rove;

For ye full oft have heard my secret sighs, And caught unseen, the tear of hopeless love;

Farewell! a long farewell !....your shades among

No more these eyes shall drink Eliza's charms:

No more these ears the music of her tongue !....

O! doom'd for ever to another's arms!

Fly, gentle steeds

Where brighter scenes and milder planets shine;

Where Joy's white pinion glitters in the ray,

And Love sits smiling on his crystal shrine!

About the summer 1778 the countess of Northesk rested at one of the inns in Lichfield, on her way to Scotland by the shortest possible stages. She had been a year in England, for the benefit of her health, wasting rapidly by hemorrhage. Ineffectually had the ost eminent physicians of London and Bath endeavoured to check the progress of her 
disease. Her youngest daughter, Lady Marianne Carnegie, then an amiable girl of thirteen, now, alas! no more, and their friend, Mrs. Scott, were the companions of Lady Northesk's journey. Her ladyship told the mistress of the inn that she was going home to die, the physicians having confessed. that art could do no more in her case. The person replied, "I wish, Madam, that you would send for "our Doctor, he is so famous." Lady Northesk consented.

When Dr. Darwin came, he observed that he could do little on transient observation, where the disease was obstinate, and of such long continuance; pressed her to remove with her daughter and friend to his house, and to remain his guests during a fortnight. The invitation was accepted. He requested the author of these memoirs frequently to visit his new patient, contribute to amuse her, and abate the inevitable injury of perpetual selfattention.

Miss Seward felt herself extremely interested in this lady, and anxious to see those sufferings relieved which were so patiently sustained. Lady Northesk lay on a couch, through the day, in Dr. Darwin's parlour, drawing with difficulty that breath, which seemed often on the point of final evaporation. She was thin, even so transparency; 
her cheeks suffused at times with a flush, beautiful, though hectic. Her eyes remarkably lucid and full of intelligence. If the languor of disease frequently overshadowed them, they were always relumined by every observation to which she listened, on lettered excellence, on the powers of science, or the ingenuity of art. Her language, in the high Scotch accent, had every happiness of perspicuity, and always expressed rectitude of heart and susceptibility of taste.

Whenever her great and friendly physician perceived his patient's attention engaged by the conversation of the rest of the circle, he sat considering her in meditative silence, with looks that expressed,...." You shall not die thus prematurely, " if my efforts can prevent it."

One evening, after a long and intense reverie, he said,...." Lady Northesk, an art was practised " in former years, which the medical world has " very long disused; that of injecting blood into " the veins by a syringe, and thus repairing the " waste of diseases like yours. Human blood, and " that of calves and sheep, were used promiscu" ously. Superstition attached impiety to the "practice. It was put a stop to in England by a " bull of excommunication from some of our Pop. " ish Princes, against the practitioners of sangui- 
" nary injection.... That it had been practised with " success, we may, from this interdiction, fairly con" clude; else restraint upon its continuance must " have been superffuous. We have a very ingeni" ous watch-maker here, whom I think I could " instruct to form a proper instrument for the pur"pose, if you choose to submit to the experiment." .....She replied cheerfully, " that she had not the "least objection, if he thought it eligible."

Miss Seward then said ...." If the trial should " be determined upon, perhaps Lady Northesk " would prefer a supply from an healthy human " subject, rather than from an animal. My health " is perfect, neither am I conscious of any lurking: " clisease, hereditary or accidental. I have no dread " of the lancet, and will gladly spare, from time to " time, such a portion from my veins to Lady Nor" thesk, as Dr. Darwin shall think proper to inject."

He seemed much pleased with the proposal, and his amiable patient expressed gratitude, far above the just claim of the circumstance. Dr. Darwin said he would consult his pillow upon it.

The next day, when Miss S. called upon Lady $N$. the Doctor took her previously into his study, telling her, that he had resigned all thoughts of trying the experiment upon Lady Northesk; that it had occurred to him as a last resource, to save an 
excellent woman, whose disorder, he feared, was beyond the reach of medicine ; "but," added he, " the construction of a proper machine is so nice an " affair, the least failure in its power of acting" so " hazardous, the chance at last from the experiment "so precarious, that I do not choose to stake my "reputation upon the risque. If she die, the world " will say I killed Lady Northesk, though the " London and Bath physicians have pronounced her " case hopeless, and sent her home to expire. " They have given her a great deal too much medi" cine, I shall give her very little. Their system " of nutritious food, their gravy jellies, and strong " wines, I have already changed for milk, vegeta" bles and fruit. No wines ever; no meat, no strong " broth, at present. If this alteration of diet prove " unavailing, her family and friends must lose her."

It was not unavailing; she gathered strength under the change from day to day. The disease abated, and in three weeks time she pursued her journey to Scotland, a convalescent, full of hope for herself, of grateful veneration towards her physician, whose rescuing skill had saved her from the grave; and full, also, of overrating thankfulness to Miss $\mathbf{S}$. for the offer she had made. With her Lady Northesk regularly corresponded from that time till her sudden and deplorable death. All Lady N.'s letters 
spoke of completely recovered health and strength. She sent Miss Seward a present of some beautiful Scotch pebbles for a necklace, picked up by her own hands in her Lord's park, and polished at Edinburgh.

Lady Northesk might have lived to old age, the blessing of her family and friends. Alas ! the time had passed by in which Miss Seward was ac. customed to expect a letter from her friend!

Inquiry taught her that Lady Northesk had perished by the dreadfully-frequent accident of having set fire to her clothes. Lady Marianne Carnegie wrote to Miss S, the year after, and continued to honour her with several letters while her Ladyship lived with her father at Ethic House, on the acean's edge. It was there that she dedicated many of her youthful years to the pious endeavour of mitigating Lord Northesk's deep anguish for the loss of his Lady, which had induced him inflexibly to renounce all society except with his own family. That might be said of Ethic House which Dr. Johnson said of the Isle of Raasay, in the Hebrides. "Without were the dark rocks, the "roaring winds, and tumuituous deep;" but alas for Lady Marianne! it could not also be said, as of Raasay, that " within were the social comforts, "the roice of gajety, the dince, and the song." 
Yet did she support, with uncomplaining patience, in the flower of her youth, this deep solitude; this monotony of natural objects, in which little variety could be found, beyond the change of smiling and frowning seas, the hushed and the bellowing waters.

In the autumn of this year Mrs. Pole of Radburn was taken ill; her disorder a violent fever. Dr. Darwin was called in, and perhaps never, since the death of Mrs. Darwin, prescribed with such deep anxiety. Not being requested to continue in the house through the ensuing night, which he apprehended might prove critical, he passed the remaining hours till day-dawn beneath a tree opposite her apartment, watching the passing and repassing lights in the chamber. During the period in which a life he so passionately valued was in danger, he paraphrased Petrarch's celebrated somnet, narrating a dream, whose prophecy was accom. plished by the death of Laura. It took place the night on which the vision arose amid his slumber. Dr. Darwin extended the thoughts of that sonnet into the following elegy:

Dread Dream, that, hovering in the midnight air,

Clasp'd with thy dusky wing, my aching head,

While, to Imagination's startled ear,

Toll'd the slow bell, for bright Eliza doad. 
Stretch'd on her sable bier, the grave beside, A snow-white shroud her breathless bosom bound, O'er her wan brow the mimic lace was tied, And loves, and virtues hung their garlands round.

From those cold lips did softest accents flow?

Round that pale mouth did sweetest dimples play?

On this dull cheek the rose of beauty blow, And those dim eyes diffuse celestial day?

Did this cold hand unasking want relieve, Or wake the lyre to every rapturous sound? How sad, for other's woe, this breast would heave! How light this heart, for other's transport, bound!

Beats not the bell again ?...Heav'ns! do I wake?

Why heave my sighs, why gush my tears anew?

Unreal forms my trembling doubts mistake, And frantic Sorrow fears the vision true.

Dream ! to Eliza bend thy airy flight, Go, tell my charmer all my tender fears, How Love's fond woes alarm the silent night, And stecp my pillow in unpitied tears.

The second verse of this charming elegy affords an instance of Dr. Darwin's too exclusive devotion 
to distinct picture in poetry; that it sometimes betrayed him into bringing objects so precisely to the eye, as to lose in such precision their power of striking forcibly upon the heart. The pathos in that second verse is injured by the words, " mimic lace," which allude to the perforated borders of the shroud. The expression is too minute for the solemnity of the subject. Certainly it cannot be natural for a shocked and agitated mind to observe, or to describe with such petty accuracy. Besides the allusion is not sufficiently obvious. The rea. der pauses to consider what the poet means by " mimic lace." Such pauses deaden sensation, and break the course of attention. A friend of the Doctor's pleaded strongly that the line might run thus,

"On her wan brow the shadowy crate was tled;"

but the alteration was rejected. Inattention to the rules of grammar in the first verse, was also pointed out to him at the same time. The dream is ad. dressed,

"Dread dream, that clasped my aching head," 
but nothing is said to it; and therefore the sense is left unfinished, while the elegy proceeds to give a picture of the lifeless beauty. The same friend suggested a change, which would have remedied the defect, thus,
"Dread was the dream, that, in the midnight air,
"Clasp'd, with its dusky wing, my aching head,
"While to, \&c."

Hence, not only the grammatic error would have been done away, but the grating sound, produced by the near alliteration of the harsh $d r$, in "dread dream," removed, by placing those words at a greater distance from each other.

This alteration was, for the same reason, rejected. The Doctor would not spare the word hovering; which he said strengthened the picture; but surely the image ought not to be elaborately precise, by which a dream is transformed into an animal, with black wings.

Soon after Mrs. Pole's recovery from her dangerous illness, Dr. Darwin wrote the following little poem, 


\section{ODE TO THE RIVER DERWEN'T,}

WRITTEN IN A ROMANTIC VALLEY NEAR ITS SOURCE.

Derwent, what scenes thy wandering waves behold, As bursting from thine hundred springs they stray, And down these vales, in sounding torrents roll'd, Seek to the shining East their.mazy way!

Here dusky alders, leaning from the cliff, Dip their long arms, and wave their branches wide; There, as the loose rocks thwart my bounding skiff, White moonbeams tremble on the foaming tide.

Pass on, ye waves, where, dress'd in lavish pride, Mid roseate bowers, the gorgeous Chatsworth beams, Spreads her smooth lawns along your willowy side, And eyes her gilded turrets in your streams.

Pass on, ye waves, where Nature's rudest clild, Frowning incumbent o'er the darken'd floods, Rock rear'd on rock, mountain on mountain pil'd, Old Matlock sits, and shakes his crest of woods.

But when fair Derby's stately towers you view, Where his bright meads your sparkling currents drink, $O$ ! should Eliza press the morning dew, And bend her graceful footsteps to your brink, 
Uncurl your eddies, all your gales confine,

And, as your scaly nations gaze around,

Bid your gay nymphs pourtray, with pencil fine,

Her radiantform upon your silver ground.

With playful malice, from her kindling cheek

Steal the warm blush, and tinge your passing stream;

Mock the sweet transient dimples, as she speaks,

And, as she turns her eye, reflect the beam!

And tell her, Derwent, as you murmur by,

How in these wilds with hopeless love I burn,

Teach your lone vales and echoing caves to sigh,

And mix my briny sorrows with your urn?

This elegiac ode is rich in poetic beauty. The epithet willowy, in the third stanza, appeared questionable, till it was recollected that it is the weeping willow that was meant, with which art has adorned the Derwent in his course through the lawns of Chatsworth. The common species of that tree has no spontaneous growth on the edge of rivers which alternately rush and flow through their rocky channel in mountainous countries. Common willows border the heavy, sluggish streams of flat and swampy situations. Dwarf-alclers, nut-trees, and other bushes of more stinted height, and darker 
verdure, fringe the banks of the Derwent, the Wie, and the Larkin, on their passage through the Peak scenery, and form a more rich and beautiful curtain than the taller, the straggling, and pale-hued willow.

Matlock is not justly called Nature's rudest child. If his rocks were without clothing, he might properly be so called. Rude gives an idea of barrenness, and Matlock is luxuriantly umbraged; much more luxuriantly than Dove Dale; while every traveller through Derbyshire must recollect, how rich and smiling the Matlock-scenery, compared to the savage magnificence of Eyam-Dale, commonly, though not properly, called Middleton-Dale.

There, indeed, we see rocks piled on rocks, unfoliaged and frowning. They form a wall, of vast height, on either side the white limestone bottom of that deep and narrow valley, with the little sparkling rill which speeds through it.

In several reaches of the curves, made by this Salvatorial Dale, it is from the temperature of the air alone that the seasons can be ascertained; since there are no trees, to mark by their foliage the reign of sylvan beauty; no grass, to denote it by its lively hue. Nothing but the grey, the barren, and lonely rocks, with, perhaps, a few stragggling Scotch firs waving on the tops of the cliffs above; and their dusky sprays neither winter strips nor spring enlivens. 
This dale is, indeed, "Peak's rudest child." Of late years, injury has been done to the towery and fantastic forms of many of the rocks, from their having been broken in pieces by gunpowder explo. sion, for the sake of mending the turnpike roads. The mills, for smelting the lead-ore in this dale, blot the summer noon, and increase its sultriness by those volumes of black smoke which pour out from their chimnies; but in the night they have a grand effect, from the flare of the pointed flames which stream amid the smoke, and appear like so many small volcanos.

Mr. Longston, of Eyam, has adorned a part of this scene by a hanging garden and imitative fort. The steep, winding paths of the garden are planted with wild shrubs, natives of the sterile soil, and which root their fibres in the fissures of the rocks. The effect, in descending those paths from the cliffs above, is very striking. They command the stupendous depths of the vale below and a considerable portion of its curre.

About the year 1777, Dr. Darwin purchased a little, wild, umbrageous valley, a mile from Lich. field, amongst the only rocks which neighbour. that city so nearly. It was irriguous from various springs, and swampy from their plenitude. A mossy fountain of the purest and coldest water imaginable, 
had, near a century back, induced the inhabitants of Lichfield to build a cold bath in the bosom of the vale. That, till the Doctor took it into his possession, was the only mark of human industry which could be found in the tangled and sequestered scene.

One of its native features had long excited the attention of the curious; a rock, which, in the central depth of the glen, drops perpetually, about three times in a minute. Aquatic plants border its top and branch from its fissures. No length of summer drought abates, no rains increase its humidity, no frost congeals its droppings. The Doctor cultivated this spot,

"And Paradise was open'd in the wild."

In some parts he widened the brook into small lakes, that mirrored the valley; in others, he taught it to wind between shrubby margins. Not only with trees of various growth did he adorn the borders of the fountain, the brook, and the lakes, but with various classes of plants, uniting the Linnæn science with the charm of landscape.

For the Naiad of the fountain, he wrote the - following inscription: 


\section{SPEECH OF A WATER NYMPH.}

If the meek flower of bashful dye, Attract not thy incurious eye;

If the soft murmuring rill, to rest Encharm not thy tumultuous breast, Go, where Ambition lures the vain, Or Avarice barters peace for gain!

Dr. Darwin restrained his friend Miss Seward's steps to this her always favourite scene till it had assumed its new beauties from cultivation. He purposed accompanying her on her first visit to his botanic garden, but a medical summons into the country deprived her of that pleasure. She took her tablets and pencil, and, seated on a flowerbank, in the midst of that luxuriant retreat, wrote the following lines, while the sun was gilding the glen, and while birds, of every plume, poured their song from the boughs :

O, come not here, ye Proud, whose breasts infold 'Th' insatiate wish of glory, or of gold ;

O come not ye, whose branded foreheads wear Th' eternal frown of envy, or of care;

For you no Dryad decks her fragrant bowers, For you her sparkling urn no Naiad pours;

Unmark'd by you light Graces skim the green, And hovering Cupids aim their shafts unseen. 
But, thou! whose mind the well attemperd ray Of Taste, and Virtue, lights witli purer day;

Whose finer sense each soft vibration owns,

Mute and unfeeling to discorded tones;

Like the fair Hower that spreads its lucid form

To meet the sun, but shuts it to the storm;

For thee my borders nurse the glowing wreath,

My fountains murmur, and my zephyrs breathe;

My painted birds their vivid plumes unfold,

And insect armies waye their wings of gold.

And if with thee some hapless maid should stray,

Disastrous love companion of her way,

O lead her timid step to yonder glade,

Whose weeping rock incumbent alders shade!

There, as meek Evening wakes the temperate breeze,

Arid moonbeams glimmer through the trembling trees,

The rills, that gurgle round, shall sooth her ear,

The weeping rock shall number tear for tear ;

And as sad Philomel, alike forlorn,

Sings to the night, reclining on her thorn,

While, at sweet intervals, each falling note

Sighs in the gale, and whispers round the grot,

The sister-woe shall calm her aching breast,

And softest slumbers steal her cares to rest.

Thus spoke the *Genius as he stept along,

And bade these lawns to Peace and Truth belong;

* By the Genius of the place is meant its first cultivator, Dr. Barwin. 
Down the steep slopes he led, with modest skill,

The grassy pathway and the vagrant rill;

Stretch'd o'er the marshy vale the willowy mound,

Where shines the lake amid the cultur'd ground;

Rais'd the young woodland, smooth'u the wavy green,

And gave to Beauty all the quiet scene.

O! may no ruder step these bowers prophane,

No midnight wassailers dcface the plain;

And when the tempests of the wintry day

Blow golden Autumn's varied leaves away,

Winds of the North, restrain your icy gales,

Nor chill the bosom of those HALLOW ED VALES!*

When Miss Seward gave this little poem to Dr. Darwin, he seemed pleased with it, and said, "I shall send it to the periodical publications; but " it ought to form the exordium of a great work. "TheLinnæn System is unexplored poetic ground, " and an happy subject for the muse. It affords fine "scope for poetic landscape; it suggests metamor-

* These verses, in their original state, as inscribed here, will be found in Mr. Shaw's History of Staffordshire, published in 1798, near four years before the death of Dr. Darwin; see Article Lichfield, page 347. Their author chose to assert her claim to them in the Doctor's lifetime, since they had appeared in the periodical publications many years before the Botanic Garden passed the press, and had borne her signaturc. 
" phoses of the Ovidian kind, though reversed. "Ovid made men and women into flowers, plants, " and trees. You should make flowers, plants, and " trees, inio men and women. I," continued he; "will write the notes, which must be scientific; "and you shall write the verse."

Miss S. observed, that, besides her want of botanic knowledge, the plan was not strictly proner for a female pen; that she felt how. eminently it was adapted to the efforescence of his own fancy.

He objected the professional danger of coming forward an acknowledged poet. It was plead. ed, that on his first commencing medical professor, there might have been danger; but that, beneath the unbounded confidence his experienced skill in medicine had obtained from the public, all risque of injury by reputation flowing in upon him from a new source was precluded; especially since the subject of the poetry, and still more the notes, would be connected with pathology.

Dr. Darwin took his friend's advice, and very soon began his great poetic work; but previously, a few weeks after they were composed, sent the verses Miss S. wrote in his Botanic Garden, to the Gentleman's Magazine, and in her name. From thence they were cupied in the Amnual Register; but, without consulting her, he had substituted for 
the last six lines, eight of his own. He afterwards, and again without the knowledge of their author, made them the exordium to the first part of his poem, published, for certain reasons, some years aiter the second part had appeared. No acknowledgment was made that those verses were the work of another pen. Such acknowledgment ought to have been made, especially since they passed the press in the name of their real author. They are somewhat altered in the exordium to Dr. Darwin's poem, and eighteen lines of his own are interwoven with them.

In September, 1780, a playful correspondence passed between Dr.. Darwin and Miss Seward, in the name of their respective cats. The subject was ludicrous as it was singular, but the mock-heroic result pleased very generally, as the permission of taking copies had been solicited and obtained by several of their acquaintance. Some literary friends of the writer of these pages, remembering the bagatelles with pleasure, persuaded her to insert them. She is apprehensive that they may be considered as below the dignity which a biographic skctch of deceased Eminence ought perhaps to preserve; yet, as in this whimsically gay effusion, Dr. Darwin appears in a new light of comic wit and sportive ingenuity, shè ventures to comply with their request: 
From the Persian Snow, at Dr. Darwin's, to Miss Po Felina, at the Palace, Lichfield.

Lichfield Vicarage, Sept. 7, 1780.

\section{Dear Miss Pussey,}

As I sat, the other day, basking myself in the Dean's. Walk, I saw you in your stately palace, washing your beautiful round face, and elegantly brinded ears, with your velvet paws, and whisking about, with graceful sinuosity, your meandering tail. That treacherous hedgehog, Cupid, concealed himself behind your tabby beauties, and darting: one of his too well aimed quills, pierced, $\mathrm{O}$ cruel imp! my fluttering heart.

Ever since that fatal hour have I watched, day and night, in my balcony, hoping that the stillness of the starlight evenings might induce you to take the air on the leads of the palace. Many serenades have I sung under your windows; and, when you failed to appear, with the sound of my voice made the vicarage re-echo through all its winding lanes and dirty alleys. All heard me but my cruel Fairone; she, wrapped in fur, sat purring with contented insensibility, or slept with untroubled dreams.

Though I cannot boast those delicate varieties of melody with which you sometimes ravish the ear of 
night, and stay the listening stars; though you sleep hourly on the lap of the favourite of the muses, and are patted by those fingers which hold the pen of science ; and every day, with her permission, dip your white whiskers in delicious cream, yet am I not destitute of all advantages of birth, education, and beauty. Derived from Persian kings, my snowy fur yet retains the whiteness and splendor of their ermine.

This morning, as I sat upon the Doctors teatable, and saw my reflected features in the slop-basin, my long white whiskers, ivory teeth, and topaz eyes, I felt an agreeable presentiment of my suit; and certainly the slop-basin did not flatter me, which shews the azure flowers upon its borders less beauteous than they are.

You know not, dear Miss Pussey Po, the value of the address you neglect. New milk have $I$, in flowing abundance, and mice pent up in twenty garrets; for your food and amusement.

Permit me this afternoon, to lay at your divine feet the head of an enormous Norway rat, which has even now stained my paws with its gore. If you will do me the honor to sing the following song, which $I$ have taken the liberty to write, as expressing the sentiments I wish you to entertain, I will bring a band of catgut and catcall, to accompany you in chorus. 
AIR :....SPIRITUOSI.

Cats I scorn, who, sleek and fat,

Shiver at a Norway rat;

Rough and hardy, bold and free,

Be the cat that's made for me!

He, whose nervous paw can take

My lady's lapdog by the neck;

With furious hiss attack the hen,

And snatch a chicken from the pen.

If the treacherous swain should prove

Rebellious to my tender love,

My scorn the vengeful paw shall dart,

Shall tear his fur, and pierce his heart.

$$
\text { CHORUS. }
$$

Qu-ow wow, quall, wawl, moon.

Deign, most adorable charmer, to pur your assent to this my request, and beleive me to be with the profoundest respect, your true admirer.

\section{SÑow.*}

* The cat, to whom the above letter was addressed, had been broken of her propensity to kill birds, and lived several years without molesting a dove, a tame lark, and a redbreast, all which used to fly about the room where the cat was daily admitted. The dove frequently sat on pussey's back, and the little birds would peck ferrlexely from the plate in which she was eating. 


\section{Answer}

\section{Paiace, Lichfield, Sept، 8, 1780。}

I am but too sensible of the charms of $\mathrm{Mr}$. Snow; but while I admire the spotless whiteness of his crmine, and the tyger-strength of his commanding form, I siogh in secret, that he, who sucked the milk of benevolence and philosophy, should yet retain the extreme of that fierceness, too justly imputed to the Grimalkin race. Our hereditary violence is perhaps commendable when we exert it against the foes of our protectors, but deserves much blame when it annoys their friends.

The happiness of a refined education was mine; yet dear Mr.-Snow my advantages in that respect were not equal to what yours might have been : but, while you give unbounded indulgence to you carnivorous desires, I have so far subducel mine, that the lark pours his mattin song, the canary-bird warbles wild and loud, and the robin pipes his farewcll song to the setting sun, unmolested in my presence; nay, the plump and temping dove has reposed securely upon my soft back, and bent her glossy neck in graceful curves as she walked around me. 
But let me hasten to tell thee how my sensibilitiesin thy favour were, 'last month, unfortunately repressed. Once, in the noon of one of its most beautiful nights, I was invited abroad by the serenity of the amorous hour, secretly stimulated by the hope of meeting my admired Persian. With silent steps I paced around the dimly-gleaming leads of the palace. I had acquired a taste for scenic beauty and poetic imagery by listening to ingenious observations upon their nature from the lips of thy own lord, as I lay purring at the feet of my mistress.

I admired the lovely scene, and breathed my sighs for thee to the listening moon. She threw the long shadows of the majestic cathedral upon the silvered lawn. I beheld the pearly meadows of Stow Valley, and the lake in its bosom, which, reflecting the lunar rays, seemed a sheet of diamonds. The trees of the Dean's Walk, which the hand of Dulness had been restrained from torturing into trim and detestable regularity, met each other in a thousand various and beautiful forms. Their liberated boughs danced on the midnight gale, and the edges of their leaves were whitened by the moon beams. I desended to the lawn, that I might throw the beauties of the valley into perspective through the graceful arches, formed by their meeting branches. Suddenly my ear was startled, not by 
the voice of my lover, but by the loud and dissonant noise of the war-song; which six black grimalkins were raising in honor of the numerous vic. tories obtained by the Persian, Snow ; compared with which, they acknowiedged those of English cats had little brilliance, eclipsed, like the unimportant victories of the Howes, by the puissant Clinton and Arbuthnot, and the still more puissant Cornwallis. It sung that though didst owe thy matchless might to thy lineal descent from the invincible Alexander, as he derived his more than mortal valour from his mother Olympia's illicit commerce with Jupiter. They sung that, amid the renowned siege of Persepolis, while Roxana and Statira were contending for the honor of his attentions, the conqueror of the world deigned to bestow them upon a large white female cat, thy grandmother, warlike Mr. Snow, in the ten thousandth and ninety-ninth ascent.

Thus far their triumphant din was music to my ear; and even when it sung that lakes of milk. ran curdling into whey, within the ebon concave of their pancheons, with terror at thine approach ; that mice squealed from all the neighbouring garrets; and that whole armies of Norway rats, crying out amain, " the devil take the hindmost," ran violently into the minster-pool, at the first gleam of 
thy white mail through the shrubs of Mr. Howard's garden.

But $\mathrm{O}$ ! when they sung, or rather yelled, of larks warbling on sunbeams, fascinated suddenly by the glare of thine eyes, and falling into thy remorseless talons; of robins, warbling soft and solitary upon the leafless branch, till the pale cheek of xvinter dimpled into joy ; of hundreds of those bright breasted songsters, torn from their barren sprays by thy pitiless fangs !... Alas! my heart died within me at the idea of so preposterous a union!

Marry you, Mr. Snow, I am afraid I cannot; since, though the laws of our community might not oppose our connection, yet those of principle, of delicacy, of duty to my mistress, do very powerfully oppose it.

As to presiding at your concert, if you extremely wish it, I may perhaps grant your request; but then you must allow me to sing a song of my orw composition, applicable to our present situation, and set to music by my sister Sophy at Mr. Brown's the organist's, thus,

ATR :....AFFETTUOSO.

He, whom Pussy Po detains

A captive in her silken chains, 
Must curb the furious thirst of prey, Nor rend the warbler from his spray!

Nor let his wild, ungenerous rage

An unprotected foe engage.

$\mathrm{O}$, should cat of Darwin prove

Foe to pity, foe to love!

Cat, that listens day by day,

To mercy's mild and honied lay,

Too surely would the dire disgrace

More deepiy brand our future race,

The stigma fix, where'er they range,

That cats can ne'er their nature change.

Should I consent with thee to wed,

These sanguine crimes upon thy head,

And ere the wish'd reform I see,

Adicu to lapping Seward's tea !

Adlieu to purring gentle praise,

Charm'd as she quotes thy master's lays !....

Could I, alas! our kittens bring

Where sweet her plumy favorites sing,

Would not the watchful nymph espy

Their father's fierceness in their eye,

And drive us far and wide away,

In cold and lonely barn to stray? 
Where the dark owl, with hideous scream,

Shall mock our yells for forfeit cream,

As on starv'd mice we swearing dine,

And grumble that our lives are nine.

\section{Chorus :..... LARGo.}

Waal, woee, trone, moan, mall, oll, moule.

The still too much admired Mr. Snow will have the goodness to pardon the freedom of these expostulations, and excuse their imperfections. The morning, $\mathrm{O}$ Snow ! had been devoted to this my correspondence with thee, but I was interrupted in that employment by the visit of two females of our species, who fed my ill-starred passion by praising thy wit and endowments, exemplified by thy elegant letter, to which the delicacy of my sentiments obliges me to send so inauspicious a reply.

I am, dear Mr. Snow, Your ever obliged, Po Felina. 


\section{CHAP.IV.}

DUR ING the course of the year 1780, died CoIonel Pole. Dr. Darwin, more fortunate than Petrarch, whose destiny his own had resembled in poetic endowment and hopeless love, then saw his adored Laura free, and himself at liberty to court her favour, whose coldness his muse had recorded; to "drink softer effusion from those eyes," which duty and discretion had rendered repulsive. He soon, however, saw her surrounded by rivals, whose time of life had nearer parity with her own, yet in its summer bloom, while his age nearly approached its half century; whose fortunes were affluent and patrimonial; while his were professional; who were jocund bachelors, while he had children for whom he must provicie.

Colonel Pole had numbered twice the years of his fair wife. His temper was said to have been peevish and suspicious, yet not beneath those cir- 
cumstances had her kind and cheerful attentions to him grown cold or remiss. He left her a jointure of six hundred pounds per annum; a son to inherit his estate, and two female children amply portioned.

Mrs. Pole, it has already been remarked, had. much vivacity and sportive humor, with very engaging frankness of temper and manners. Early in her widowhood she was rallied, in a large company, upon Dr. Darwin's passion for her, and was asked what she would do with her captive philoso. pher. " He is not very fond of churches, I believe, " and if he would go there for my sake, I shall " scarcely follow him. He is too old for me."... "Nay, madam, what are fifteen years on the right " side?" She replied, with an arch smile, "I have had so much of that right side!"

The confession was thought inauspicious to the Doctor's hopes; but it did not prove so; the triumph of intellect was complete. Without that native perception and awakened taste for literary excellence, which the first charming Mrs. Darwin possessed, this lady became tenderly sensible of the flattering difference between the attachment of a man of genius, and wide celebrity, and that of young fox-hunting: esquires; dashing militaries, and pedantic gownsmen; for she was said to have specimens of all these classes in her train. They could 
speak their own passion, but could not immortalize her charms. However benevolent, friendly, and sweet-tempered, she was not perhaps exactly the woman to have exclaimed with Akenside,

"6 Mind, mind alone, bear witness earth and heaven!

" The living fountain in itself contains

" Of beauteous and sublime!"”

Yet did her choice support his axiom when she took Dr. Darwin for her husband. Darwin, never handsome, or personally graceful, with extremely impeded utterance; with hard features on a rough surface; older much in appearance than in reality; lame and clumsey!.... and this when half the wealthy youth of Derbyshire were said to have disputed the prize with him.

But it was not without some stipulations, apparently hazardous to his pecuniary interest, that Mrs. Pole was persuaded to descend from her Laura-cminence to wifehood, and probably to silence for ever, in the repose of possession, those tender strains, which romantic love and despair, and afterwards the stimulating restlessness of doubtful hope, had occasionally arvakened. 
During that visit to Dr. Darwin, in which Mrs. Pole had brought her sick children to be healed by his skill, she had taken a dislike to Lichfield, and decidedly said, nothing could induce her to live there. His addresses did not subdue that resolve.

After so long and prosperous a residence, to quit that city, central in the Mercian district, from whence his fame had diffused itself through the circling counties, seemed a great sacrifice; but the philosopher was too much in love to hesitate one moment. He married Mrs. Pole in 1781, and removed directly to Derby. His reputation and the unlimited confidence of the public followed him thither, and would have followed him to the metropolis, or to any provincial town, to which he might have chosen to remove.

Why he constantly, from time to time, withstood solicitations from countless families of rank and opulence, to remove to Londion, was never ex. actly understood by the writer of these memoirs. She knows that the most brilliant prospects of success in the capital were opened to him, from various quarters, carly on his residence at Lichfield, and. that his attention to them was perpetually requested by eminent peoplc. Undoubtedly those prospects acquired added strength and lustre each year be- 
neath the ever-widening spread of his fame. Conscious of his full habit of body, he probably thought that the established custom of imbibing changed and pure air by almost daily journies into the country, essential to his health; perhaps to the duration of his life. In allusion to that perpetual travelling, a gentleman once humorously directed a letter, "Dr. Darwin, upon the road." When himself wrote to Dr. Franklin, complimenting him on having united philosophy to modern science, he directed his letter merely thus, "Dr. Franklin, America;" and said he felt inclined to make a still more flattering superscription. "Dr. Franklin, the World." His letter reached the sage, who first disarmed the lightning of its fatal power, for the answer to it arrived, and was shown in the Darwinian circles; in which had been questioned the likelihood of Dr. Franklin ever receiving a letter of such general superscription as the whole western empire. Its safe arrival was amongst the triumphs of genius combined with exertion, "they make the world their country."

From the time of Dr. Darwin's marriage and removal to Derby, his limited biographer can only trace the outline of his remaining existence; remark the dawn and expansion of his poetic fame, and comment upon the claims which secure its immortality. The less does she regret this limitation. 
as Mr. Dewhurst Bilsbury, his pupil in infancy, his confidential friend, and frequent companion through ripened youth, is now writing at large, the life of Dr. Darwin, who once more became an happy husband, with a second family of children, springing fast around him. To those children the Miss Poles, as themselves grew up to womanhood, were very meritoriously attentive and attached. The eldest Miss Pole married Mr. Bromley, and is said to be happy in her choice of a worthy and amiable man. The second Miss Pole gave her lovely self to Mr. John Gisborne, younger brother to the celebrated moralist and poet of that name.

Mr. John Gisborne's philosophic energies, poetic genius, extensive benevolence, ingenuous modesty, and true piety, render him a pattern for all young men of fortune, and an honour to human nature. In the year 1797 , he published a spirited and elegant local poem, entitled, "The Vales of Weaver." It is evidently of the Darwinian school, though in a shorter measure, and has genius to support the peculiar manner of poetic writing which it emulates and has caught. In this poem we meet appropriate and vivid landscape. Some of the epithets are perhaps exceptionable, and too free use is made of the word glory in several instances, particularly in its application to moon-light. Pope's 
faulty, though admired simile, in the last passage of the eighth book of the Iliad, has misled succeeding poets; inducing them to lavish upon the lunar effusions those terms of superlative splendor which they should reserve for the sun in his strength. The Bard of Twickenham, so generally discriminating, is indiscriminate when he styles the moon " refulgent lamp of night," and its white and modest beams " a flood of glory." Scholars say, he found no example in the original passage for this sun-defrauding magnificence. We clo not find it for the moon in Cowper's more literal translation of the Homeric landscape, two sins against truth pardoned, and the scene, as penciled by Cowper; is beautiful, thus :

As when around the clear, bright moon, the stars

Shine in full splendor, and the winds are hush'd,

The groves, the mountain tops, the headland heights,

Stand all apparent; not a vapor streaks

The boundless blue, but $x$ ther, open'd wide,

All glitters, and the shepherd's heart is cheer'd.

Surely the original does not sanction an image which nature never presents, since when the moon is clear and bright, the stars do not spangle the firmament plenteously, or splendidly. A few stars, and never more than a few, sometimes glimmer through her 
flood of snowy and absorbing light. At any rate, splendor is a false term. When the night is cloudless, and the moon absent, the stellar host glows and sparkles very brightly; but its resulting mass of light by no means amounts to splendor.

Nature hallows, and poetry consecrates all the moon-light scenery in Milton. It is never more charming than in the following instance:

........... Now glow'd the firmament

With living sapphires. Hesperus; that led

The starry host, rode brightest, till the moon,

Rising in clouded majesty, o'er all

Apparent queen, unveil'd her peerless light,

And o'er the dark her silver mantle threw.

Since Pope and Cowper, as translators of Homer, have been brought into a degree of comparison on these pages, the writer of them cannot resist the avowal of her opinion, that, on the whole, and considered merely as poems, great superiority is with Pope, as to perspicuity, elegance, and interest; the grace of picture, and the harmony of numbers. In a few striking passages Cowper may be the nobler, but his muse is for ever visibly and awkwardly struggling for literality, where he should have remombered the painter's adage, "It is bet. 
" ter to sin against truth than beauty," so long as the sense is not perverted, and nature is not outraged by inappropriate epithets, which must always injure the distinctness of imagery and landscape.

If, in the preceding instance, Coipper's moonlight is chaster than Pope's, see how much more grandly the rhyme translation gives the remaining lines of that closing passage :

So numerous seem'd those fires, the bank between

Of Zanthus, blazing, and the fleet of Greece,

In prospect all of Troy; a thousand fires

Each watch'd by fifty warrior's, seated near.

The steeds beside the chariot stood, their corn

Chewing, and waiting till the golden-thron'd Aurora should restore the light of day.

COWPER's HOMER, first edition.

Nothing can be more confused and unhappy than the language of this passage. It is left doubtful whether it is the fires that are blazing, or the river that by reflection blazes; and, " the bank between," is strange language for "between the banks." Chewing seems below the dignity of heroic verse, and the compound epithet golden-thron'd, fine in itself, is ruined as to effect, by closing the line when its substantive begins the next. Observe 
how exempt from all these faults is Pope's translation of the same paragraph.

So many flames before proud Ilion blaze, And lighten glimmering Zanthus with their rays.

The long reflection of the distant fires

Gleam on the walls, and tremble on the spires.

A thousand piles the dusky horrors gild,

And shoot a shady lustre o'er the field.

Full fifty guards each flaming pile attend,

Whose umber'd arms, by fits thick flashes send.

Loud neigh the coursers o'er their heaps of corn,

And ardent warriors wait the rising morn.

Poetry has no picture more exquisite than we meet in the second, third, and fourth lines ; but an infinite number, equally vivid and beautiful, rise to the reader's eye, as it explores the pages of Doctor Darwin's Botanic Garden.

While the powers of metrical landscape-painting are the theme, not unwelcome to those who feel its inchantment, will be instances which must prove that they are possessed by Mr. John Gisborne in a degree which would disgrace the national taste if they should be suffered to pass arvay without their fame. "The Vales of Weaver" is this young man's first publication. Beneath thank- 
less neglect, the efflorescence of a rich imagination will probably sink blighted, like the opening flowers of the spring berore an eastern mildew, no more to rise in future compositions to the view of that public which had estimated so coldly the value of the first.

We have read various descriptions of a winter's night, and its ensuing morning; but the following sketch is not borrowed from any of them. We feel that it was drawn beneath a lively remem. brance of real impression made on the author's mind by the circumstances themselves : therefore it will not fail to touch the vibrating chords of recollected sensation in every reader of sensibility. Book-made descriptions are trite and vapid; but nature is inexhaustible in her varieties, and will always present to the eye of genius either new images, or such combination of images as must render them new; and they will rise on his page in the monning freshness of originality. These sacred arcana she reserves for the poet, and leaves the mere versifier to his clull thefts.

\section{VALES OF WEAVER.}

O Wontton! oft I love to hear

Thy wintry whirlwinds, loud and clear; 
With dreadful pleasure bid them fill

My listening ear, my bosom chill.

As the sonorous North assails

Weaver's bleak wilds, and leafless vales,

With a wful majesty of might

He bursts the billowy clouds of night;

Booms* the resounding glens among,

And roaring rolls his snows along.

In clouds against my groaning sash

Broad, feathery flakes incessant dash,

Or wheel below, and mingling form

The frolic pageants of the storm.

Hark! with what aggravated roar

Echo repeats her midnight lore;

Rends her clark solitudes and caves,

And bellowing shakes the mighty gravest.

Couch'd on her seat the timid hare

Listens each boisterous sweep of air;

Or peeps yon blasted furze between,

And eyes the snow-bewildered scene;

Instant retracts her shuddering head,

And nestles closer in her bed.

All sad and ruffled, in the grove

The fieldfare wakes from dreams of love;

Hear's the loud north and sleety snow,

And views the drifted brakes below ;

Swift to her wing returns her beak,

And shivers as the tempests break.

* A word admirably expressing the noise of winds, and appiied to it here for the first time in poetry.

$\uparrow$ The numerous tumuli on Weaver and the adjacent hills. 
Up starts the village-dog aloof,

And howls beneath his rifted roof;

Looks from his den, and blinking hears

'The driving tumult at his ears!

Instant withdraws his fearful breast,

Shrinks from the storm, and steals to rest.

So* shrinks the pining fold, and sleeps

Beneath the valley's vaulted deeps;

Or crops the fescue's dewy blade,

And treads unseen the milky glade;

Forms by its breatlı fair opening bowers,

Transparent domes, and pearly showers.

Thus night rolls on till orient dawn

Unbars the purple gates of morn,

Unfolds each vale and snow-clad grove,

Mute founts and glossy banks above.

'Thin streaky clouds, convex'd by storms,

Slowly expand their tissued forms;

* So shrinks the fining fold. I It often happens that sheep in this and in the Peak country, are immersed many feet deep in snow for several days before they are discovered. The perpetual steam from their nostrils keeps the snow, immediately over their heads, in a dissolving state, and hence a tunnel is constantly forming through the heaps above. This tunnel greatly facilitates their discovery, and supplies them with abundance of freslh air. The warmth of these animals soon dissolves the surrounding snow, and at length the drift is so completely vaulted, that they are able to stretch their limbs, and search for subsistence. It is asserted that sheep have been frequently found alive after having been entombed in the snow during a forisight. 
Long bars of grey and crimson bright

Divert the golden threads of light;

Till glory's nascent curve displays

One splendid orb, a world of rays!

Then lightens heaven's etherial bound,

And all the spangled country glows around.

Now that we have observed what power this author possesses to bring back to our recollection a stormy night in winter, succeeded by a ruddy dawn, blazing upon its frosted landscape, let us turn to his misty morning, in the same season, gradually clearing up into a mild and sunny day.

When winter's icy hand

Whitens Britannia's shivering land,

Then slow the billowy vapors glide,

And roll their lazy oceans wide.

Oft have I mark'd from Mathfield's brow,

Her'mist-embosom'd realms below,

While, here and there, a soaring tree

Waded amid the vapory sea,

And Ashbourn's spire to distant sight

Tower'd, like a mast in dubious light.

If, through the paly gloom, the sun

With struggling beams his journey won,

Soon as he rais'd his crimson eye

With transport flash'd th' illumin'd sky;

The vane, rekindling at his blaze,

Shot, like a meteor, through the haze; 
The trees in liquid lustre flow'd, And all the dim transparence glow'd,

" ................................................

[c...................................................

The rustic, on his fields below,

Shoves from his lot the melting snow;

Salutes the welcome change, and seems

To taste of life's diviner streams;

Breathes with delight the temperate air,

And views, with half-clos'd eyes, the boundless glare.

What a pretty summer scene rises in the following verses from the same poem!

............ Wide spread

An elm uprears his reverend head;

His front the whispering breeze receives,

The blue sky trembles through it's leaves;

A cottage group beneath his shade,

Their locks with flower's and rushes braid;

And, gurgling round dark becls of serlge,

A brook just shows it's silver edge.

But now, turning from The Vales of Weaver, let us seck the Botanic Garden. The commencement of that poem in 1779 has been previously

* A Lapland scene, which succceds to the last line, is omitted, not from its want of poetic beauty, but merely to shorten the quctation. 
mentioned with the circumstance which gave it birth. It consists of two parts ; the first contains the Economy of vegetation, the second the Loves of the Plants. Each is enriched by a number of philosophical notes. They state a great variety of theories and experiments in botany, chemistry, electricity, mechanics, and in the various species of air, salubrious, noxious, and deadly. The discoveries of the modern professors in all those sciences, are frequently mentioned with praise highly gratifying to them. In these notes explanations are found of every personified plant, its generic history, its local situation, and the nature of the soil and climate to which it is indigenous; its botanic and its common name.

The verse corrected, polished, and modulated with the most sedulous attention; the notes involving such great diversity of matter relating to natural history; and the composition going forward in the short recesses of professional attendance, but chiefly in his chaise as he travelled from one place to another, the Botanic Garden could not be the work of one, two, or thiree years; it was ten from its primal lines to its first publication. The immense price which the bookseller gave for this work, was doubtless owing to considerations which inspired his trust in its popularity. Botany was, at that 
time, and still continues a very fashionable study. Not only philosophers, but fine ladies and gentlemen, sought to explore its arcana. This poem, therefore, involved two classes of readers by whom it would probably be purchased. Every skilful Botanist, every mere Tyro in the science, would wish to possess it for the sake of the notes, though insensible, perhaps, as the veriest rustic, to the charms of poetry ; while every reader, awakened to them must be ambitious to see such a constellation of poetic stars in his library; all that gave immortality to Ovid's fame, without the slightest imitation of his manner, the least debt to his ideas; since, though Dr. Darwin often retells that poet's stories, it is always with new imagery and heightened interest.

Certainly it was by an inversion of all custom that Dr. Darwin published the second part of his poem first. The reason given for so extraordinary a manouvre in that advertisement which led the younger sister before the elder on the field of public exhibition, is this, that the appearance of the first part had been deferred till another year, for the purpose of repeating some experiments in vegetation.

The Doctor was accustomed to remark, that whenever a strange step had been taken, if any way obnoxious to censure, the alleged reason was 
scarcely ever the real motive. His own singular management in this instance, and the way in which he accounted for it, proved a case in point. He was conscious that the second part of his work would be more level than the first to the comprehension, more congenial to the taste of the superficial reader, from its being much less abstract and metaphysic, while it possessed more than sufficient poetic matter to entertain and charm the enlightened and judicious few. They, however, he well knew, when his first part should appear, would feel its superiority to the earlier publication, its grander conceptions, its more splendid imagery, though less calculated to amuse and to be understood by common readers. Those of that last number who had purchased the first part would not like to possess the poem incomplete, and therefore would purchase the second. The observations of this paragraph refer to the poetry of the work, and to the two classes of readers who would value it chiefly on that account. The notes to each part must render them equally valuable to the votaries of botany, and other modern sciences.

It is with just and delicate criticism that Mr. Fellows again observes of Dr. Darwin's poetry: "In perspicuity, which is one of the first excel"lences in poetic as well as prose composition, this 
" author has perhaps few equals. He is clear, even " when describing the most intricate operations " of nature, or the most complex works of art; " and there is a lucid transparency in his style "through which we see objects in their exact " figure and proportion: but Dr. Darwin's poetry " wants sensation; that sort of excellence which, " while it enables us to see distinctly the objects " described, makes us feel them acting on our " nerves."

A little reflection is, perhaps, necessary precisely to understand this criticism, distinguishing between vivid poetry which does not excite sensation, and vivid poetry which does excite it. Instances will best elucidate the distinction. See the two following descriptions of a wintery evening, late in autumn :

\section{BOTANIC GARDEN.}

Then o'er the cultur'd lawns and dreary waste,

Retiring Autumn flings her howling blast,

Bends in tumultuous waves the struggling woods,

And showers her leafy honors on the floods,

In withering heaps collects the flowery spoil, And each chill insect sleeps beneath the soil.

Quoted from a sonnet of Mr. C. Lloyd's pub. lished with Mr. Colridge's poems. 
Dismal November! me it sooths to view,

At parting day, the scanty foliage fall

From the wet fruit-tree, or the grey stone wall,

Whose cold films glisten with unwholesome dew;

To watch the sweepy mists from the dank earth

Enfold the neighbouring copse, while, as they pass,

The silent rain-drop bends the long, rank grass,

Which wraps some blossom's immatured birth ;

And, through my cot's lone lattice, glimmering grey,

Thy damp chill evenings have a charm for me,

Dismal November!

The picture is equally just and striking in both the above quotations; but the first, though more dignified, does not thrill our nerves; and the second does. We admire in the former the power and grace of the poet; in the latter we forget the poet and his art, and only yearn to see images renected in his mirror, which we have annually, and many times shuddered to survey in real life.

When Dr. Darwin describes the glow-worm, supposing its light to be phosphoric, he thus exhorts his allegoric personages, the nymphs of fire, mean. ing the electrical powers:

Warm, on her mossy couch, the radiant worm, Guard from cold dews her love-illumin'd form,

From leaf to leaf conduct the virgin light,

Star of the earth, and diamond of the night! 
Nothing can be more poetic, more brilliant than this picture; yet, when Shakspeare says,

of The glow-worm shows the morning to be near,

"And 'gins to pale his ineffectual fire,"

we feel sensation which the more resplendent picture of this insect had failed to inspire, notwithstanding the pleasure it had given us, the admiration it had excited.

Probably the reason why Dr. Darwin's poetry, while it delights the imagination, leaves the nerves at rest, may be, that he seldom mixes with the picturesque the (as it is termed in criticism) moral epithet, meaning that quality of the thing mentioned, which pertains more to the mind, or heart, than to the eye, and which, instead of picture, excites sensation. Shakspeare gives no distinct picture of the glow-worm, since the only epithet he uses for it is not descriptive of its appropriate lustre, which has a tint specified in the ensuing quotation :

"6........... From the bloom that spreads

"Resplendent in the lucid morn of May,

6 'To the green light the little glow-worm sheds

" On mossy banks, when midnight glooms prevail,

"And silence broods o'er all the shelter'd dale:" 
If Dr. Darwin also omits to mention the particular hue of this insect, when it is luminous, he conveys that hue to the imagination when he says, "Star of the earth," since the largest and brightest stars have the same master-tint. Ossian says, "Night is dull and dark, no star with its green, trembling beams!"

But Shakspeare's moral epithet ineffectual, does better than paint its object. It excites a sort of tender pity for the little insect, shining without either warmth or useful light, in the dark and lonely hours.

\section{BOTANIC GARDEN.}

And now the rising moon, with lustre pale,

O'er heaven's dark arch unfurls her milky veil.

This picture is charming: yet when Milton paints the same object thus,

$$
\text { "............ Now reigns, }
$$

"Full orb'd, the moon, and with more pleasant light,

"Shadowy, sets off the face of things,"

the charm is on the nerves, as well as on the eye. The moral epithet pleasant, excites sensation, while the picturesque epithet, shadowy, has all the 
truth, the grace, and power of the pencil. It is that charm on the nerves to which Mr. Fellowes so well applies the word, sensation. It seems a new term in criticism, and is useful to express what pathos would express too strongly, and therefore with less accuracy. Pathos is the power of affecting the heart; by sensation is meant that of acting upon the nerves.

Beneath their torpor, the heart, or the passions, cannot be affected; but the nerves may be awakened to lively, or pensive pleasure, by composition which, not exciting any positive passion, may not act upon the heart in a degree to justify the application of the word, pathetic; and for this gentler, subtler, and more evanescent infuence, which almost imperceptibly touches the passions without agitating them, Mr. F.'s term is happy.

Dr. Darwin's excellence consists in delighting the eye, the taste, and the fancy, by the strength, distinctness, elegance, and perfect originality of his pictures; and in delighting the ear by the rich cadence of his numbers; but the passions are generally asleep, and seldom are the nerves thrilled by his imagery, impressive and beauteous as it is, or by his landscapes, with all their vividness.

It may, however, be justly pleaded for his great work, that its ingenious and novel plan did 
not involve any claim upon the affections. We are presented with an highly imaginative and splendidly descriptive poem, whose successive pictures alternately possess the sublimity of Michael Angelo, the correctness and elegance of Raphael, with the glow of Titian; whose landscapes have, at times, the strength of Salvator, and at others the softness of Claude; whose numbers are of stately grace, and artful harmony; while its allusions to ancient and modern history and fable, and its interspersion of recent and extraordinary anecdotes, render it extremely entertaining. Adapting the past and recent discoveries in natural and scientific philosophy to the purposes of heroic verse, the Botanic Garden forms a new class in poetry, and by so doing, gives to the British Parnassus a wider extent than it possessed in Greece, or in ancient, or modern Rome.

Nor is it only that this composition takes unbeaten ground, and forms an additional order in the fanes of the Muses, it forms that new order so brilliantly, that though it may have many imitators, it will probably never have an equal in its particular class ; neither would its style apply happily to subjects less intrinsically picturesque. The specics of praise here given to this work is all that its author desired to excite. We have no right to com- 
plain of any writer, or to censure him for not possessing those powers at which he did not aim, and which are not necessarily connected with his plan.

To the subject Dr. Darwin chose, his talents were eminently calculated. Neither Pope nor Gray would have executed it so well; nor would Darwin have written so fine an Essay on Man, so inter. esting a Churchyard, or so lovely an Ode on the prospect of the school at which he was educated, had that school been Eton. He would not have succeeded so transcendently on themes, which demanded either pathos, or that sort of tender and delicate feeling in the poet, which excites in the reader sympathetic sensation; or yet in the sacred morality of ethic poetry, which however it may admit, or require that fancy adorn it with some rare, and lovely flowers, " allow to ornament but a " second place, and always renders it subordinate " to intrinsic worth and just design." To whomsoever he might have been practically inferior on themes he has left unattempted, he is surely not inferiur to Ovid; and if poetic taste is not much degenerated, or shall not hereafter degenerate, the Botanic Garden will live as long as the Metamorphoses.

That in his poetic style Dr. Darwin is a mannerist cannot be denied; but so was Milton, in 
the Paradise Lost; so was Young, in the Night Thoughts; so was Akenside, in the Pleasures of Imagination. The Darwinian peculiarity is in part formed by the very frequent use of the imperative mood, generally beginning the couplet either with that, or with the verb active, or the noun personal. Hence, the accent lies oftener on the first syllable of each couplet in his verse than in that of any other rhymist; and it is, in consequence, peculiarly spirited and energetic. Dr. Darwin's style is also distinguished by the liberal use of the spondee, viz. * two monosyllables, equally accented, following each other instantly in some part of the line.

Spondees, judiciously used, vary and increase the general harmony in every species of verse, whether blank or rhyme. They preserve the numbers from too luscious sweetness, from cloying sameness, from feeble elegance, and that, by contrasting the smoothness of the dactyls, and the rich melodies of the iambic accents. So discords resolv. ing into concords, inspirit the strains of musical composition. But it is possible to make too frequent use of the spondee in poetry, as of the discord in music. Dr. Darwin's ear preserved him from that exuberance; but Mr. Bowles, one of the

* This explanation is for the ladies. 
finest poets of this day, often renders his versification, which is, at times, most exquisitely sweet, harsh, by the too frequently-recurring spondee.

From that gentleman's verse a couple of instances may be selected, to show, in one, that harmony may be improved by a sparing use ot that accent, and injured in the other by using it too freely.

MR. BOWLES' HOPE.

But lusty enterprise, with looks of glee,

Approach'd the drooping youth, as he would say,

Come to the rild roods and the hills with mé,

And throw thy sullen myrtle wreath away!

\section{BOWLES' ELEGIAC STANZAS.}

Hast thou * not visited that pleasant place,

Where in this hard roorld I have happiest been,

And shall I tremble at thy lifted mace,

That hath fierc'd all on which life seem'd to lean?

The recurrence of two equally accented words three times in the stanza, and twice in the last line, incumbers the versification, while the single use of the spondee in the preceding four lines, from Hope, gives it grace and beauty. Dr. Darwin, in the following passage, has used it frequently, without producing any such dead weight upon the verse. The 
quotation is from the charge of the Botanic Queen to the Nymphs of Fire, a poctic allegory for the influence of the fluid matter of heat in forwarding the germination and growth of plants.

Pervade, pellucid forms, their cold retreat!

Ray, from bright orbs, your viewless floods of heat !

From earth's deeh wastes electric torrents pour,

Or shed from heav'n the scintillating shower!

Pierce the dull root, relax its fibre trains,

Thaw the thick blood that lingers in its veins!

Melt with warm breath, the fragrant gurns that bind

Th' expanding foliage in its scaly rind!

And as in air the laughing leaflets play,

And turn their shining bosoms to the ray,

Nymphs, with sweet smile, each opening flower invite,

And on its damask eyelids pour the light!

On reflection, it should seem that it is the situation of these twin accents in the line, which prevent their frequent recurrence from producing harshness. It will be observed in the last quotittion, that all the many spondees are preceded by two syllables; and that it is only when they are preceded by an odd syllable, either one or three, that they increase the harmony by their sparing, and injure it by their frequent appearance. One 
syllable only goes before the spondee in this line from the Botanic Garden.

The wan'stars glimmering through the silver train.

Three syllables in this verse from the same poem.

Where now the South -sea heaves its waste of froth.

Again,

Loud shrieks the lone thrush from his leafless thorn.

And, in that last instance, the spondee recurring twice in one line, harshness is the result. Once used only, and the harshness had been avoided; thus,

And shrieks the lone thrush from the leafless thorn.

The following is a couplet where the spondee succeeding to three monosyllables has an exquisite effect of sound echoing sense.

\section{BOTANIC GARDEN.}

With paler lustre where Aquarius burns, And showers the still snowv from his hoary urns.

We find another striking peculiarity in Dr. Darwin's style, that of invariably presenting a class by an impersonified individual; thus, 
Where, nurs'd in night, incumbent tempest shrouds

The seeds of thunder in circumfluent clouds.

Again,

Where, with chill frown, enormous Alps alarms

A thousand realms horizon'd in his arms.

Again,

Sailing in air, when dark Monsoon enshrouds

His tropic mountains in a night of clouds.

Similar instances crowd the pages of the Bo. tanic Garden. There is extreme sublimity in the whole of that passage, which converts the monsoon winds into an individual monster,

That showers on Afric all his thousand urns.

Dr. Johnson, Mr. Burke, and Dr. Parr, have the same habit in their prose; "Criticism pro" nounces," instead of " Critics pronounce." "Malignance will not allow," instead of "Malig" nant people will not allow." "Good-nature re"fuses to listen," instead of " a good natured man "refuses to listen," and so on.

This manner of writing, whether in verse or prose, sweeps from the polished marble of poetry 
and eloquence, a number of the sticks and straws of our language; its articles, conjunctives, and prepositions. Addison's serious Essays are so littered with them and with idioms, as to rencler it strange that they should still be considered as patterns of didactic oratory. No man of genius, however adopts their diffuse and feeble style, now that the strength, the grace, and harmony of prose-writing, on the dignified examples of our later essayists, senators, and pleaders, give us better examples. These observations relate solely to the grave compositions of the celebrated Atticus. The quiet, easy, elegant gaiety of his comic papers in the Spectator, remains unrivalled.

It has been already observed in the course of this tract, that Dr. Darwin's muse ranges through nature and art, through history, fable, and recent anecdote, to vary, inspirit, and adorn this her luxuriant work. If she impersonizes too lavishly; if devoted to picture, she covers every inch of the walls of her mansion with landscapes, allegoric groups, and with single figures; if no instersticial space is left to increase the effect of these splendid forms of the imagination: yet be it remembered, that it is always in the reader's power to draw each picture from the mass, and to insulate it by his attention.' It will recompense by its grandeur, its beanty, or its terrific grace, the pains he may take 
to view it in every light, ere he proceeds to examine ather objects in the work, which he will find of equal force and skill in their formation.

Dr. Darwin gives us, in this poem, classic fables from Homer, Virgil, and Ovid, and so gives them, places the persons of each little drama. in such new and interesting situations and attitudes, that he must indeed be a dull prose-man who shall exclaim undelighted, "This is an old story." 


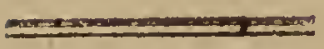

\section{CHAP. V.}

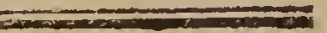

Analysis of the first part of the Botanic Garden.

\section{THE ECONOMY OF VEGETATION.}

After that landscape of the scene which forms the exordium, the Goddess of Botany descends in gorgeous gaiety:

She comes! the Goddess ! thro' the whispering air,

Bright as the morn, descends her blushing car ;

Each circling wheel a wreath of flowers entwines;

And gremm'd with flowers the silken harness shines;

The golden bits with flowery studs are deck'd,

And knots of flowers the crimson reins connect.

And now on earth the silver axle rings,

And the shell sinks upon its slender springs;

Light from her airy seat the Groddess bounds,

And steps celestial press the pansied grounds. 
Spring welcomes her with fragrance and with song, and, to receive her commissions, the four elements attend. They are allegorised as Gnomes, Water-Nymphs, Sylphs, and Nymphs of Fire. Her address to each class, and the business she allots to them, form the four Cantos of this first part of the poem.

The Ladies of Ignition receive her primal attention. The picture with which her address commences, is of consummate brilliance and grace ; behold it, reader, and judge if this praise be too glowing!

Nymphs of primeval fire, your vestal train

Hung with gold tresses o'er the vast inane;

Pierc'd with your silver shafts the throne of night, And charm'd young Nature's opening eyes with light, When Love Divine, with brooding wings unfurl'a Call'd from the rude abyss the living world.

The Darwinian creation, which ensues, charms us infinitely, even while we recollect its simpler greatness on the page of Moses, and on its sublime paraphrase in the Paradise Lost. The creation in this poem is astronomic, and involves the universe; and as such is of excellence yet unequalled in its kind, and never to be excelled in the grandeur of its conceptions. 
Let there be light, proclaim'd th' A lmighty Lord, Astonish'd Chaos heard the potent word; Through all his realms the kindling ether runs, And the massstarts into a million suns. Earths round each sun, with quick explosion, burst, And second planets issue from the first; Bend, as they journey, with projectile force, In bright ellipsis, their reluctant course;

Orbs wheel in orbs, round centres centres roll, And form, self-balanc'd, one revolving whole; Onward they move, amid their bright abode, Space without bound, the bosom of their God.

The word of the Creator, by an allusion to the effects of a spark upon gunpowder, setting into instant and universal blaze the ignited particles in Chaos, till they burst into countless suns, is an idea sublime in the first degree.

The subsequent comments of the Goddess on the powers of the Nymphs of Fire, introduce lovely pictures of the lightning and the rainbow; the exterior sky, the twilight, the meteor, the aurora borealis; of the planets, the comet, and all the etherial blazes of the universe.

She next exhibits them as superintending the subterranean and external volcanos.

You, from deep cauldrons and unmeasur'd caves.

Blow flaming airs, or pour vitgescent wares! 
O'er shining oceans ray volcanic light,
Or hurl innocuous embers through the night.

She compares them to Venus and her Nymphs; after they had descended to the cave of Vulcan. The classic fable forms a varied and lively little drama. The Goddess proceeds to remind her hand-maids of their employments: says, they lead their glittering bands around the sinking day, and when the sun retreats, confine, with folds of air, his lingering fires to the cold bosom of earth.

O'er eve's pale forms diffuse phosphoric light, And deck with lambent flames the shrine of night.

Surely there cannot be a more beautiful description of a vernal twilight. The phosphorescent quality of the Bolognian stone, Beccari's prismatic shells, and the harp of Memnon, which is recorded to have breathed spontaneous chords when shone upon by the rising sun, are all compared to the twilight glimmerings of the horizon; so also the luminous insects, the glow-worm, the fire-flies of the tropics, the fabulous ignis fatuus, and the gymnotus electricus, brought to England from Surinam in South America, about 
the year 1733; a fish, whose electic power is, on provocation, mortal to his enemy. He is compared to the Olympic eagle, that bears the lightning in its talons.

Dr. Darwin considers the discovery of the uses of fire, as the earliest and most important of the artificial comforts. Hence, the Goddess praises her nymphs of that element, as the primal instructers of savage man. Its dangerous excellence is illustrated by the severe beauty of the serpent-haired Medusa, as it blazes on the shield of Minerva.

They are next addressed as the patronesses of chemistry; teaching the uses of gunpowder, and inspiring Captain Savery with the invention of the steam-engine. The unpoetical name renders this introduction of a real person amidst allegoric beings, unhappy; especially since no dramatic circumstance in his destiny recompenses the infelicity. A description of that eminently useful machine is given with the accuracy of a mechanic philosopher, and the dignity of a great poet. A prophecy follows, that its powers will, in future times, be applied to the purposes of facilitating land and water carriage, and in navigating balloons. 
The wonderful effects of this vast machine are supposed to resemble the exploits of Hercules, and several of those exploits are very finely pictured.

All the operations of electricity next pass in review; a lovely female receiving the shock on a waxen elevation; also a circle of young men and women electrified. Their resulting sensations are described with perfect truthand elegance, and the effects of this discovery in paralytic cases are thus exquisitely mentioned.

Palsy's cold hands the fierce concussion own, And Life clings trembling on her tottering throne.

Such powers in this artful lightning are compared to those of the natural; its deleterious excess, to the fire of heaven that scathes the oak; its milder degree, to the fairy rings, which the poet believes to have been imprinted by the flashes of the thunder storm darting on the grass and circularly blighting it.

The disastrous fate of professor Richman, at Petersburgh, pursuing electric experiment with fatal temerity, rises to the eye, and makes the reader a shuddering spectator of its progress and result. 
Dr. Franklin, with his preserving rods, is compared to the celebrated Florentine Gem, Cupid snatching the lightnings from Jupiter, which the poet considers as a noble allegory, representing Divine Justice disarmed by Divine Love. The poetic scene, from the Gem, is one of the sweetest little dramas of this poem; so sweet, there is no resisting the temptation of here exhibiting it to those to whom the work itself may not instantly be accessible.

Thus when, on wanton wing, intrepid Love Snatch'd the rais'd lightning from the arm of Jove, Quick o'er his knee the triple bolt he bent, The cluster'd darts and forky arrows rent; Snapp'd, with illumin'd hands, each flaming shaft, His tingling fingers shook, and stamp'd, and laugh'd. Bright o'er the floor the scatter'd fragments blaz'd, And Gods, retreating, trembled as they gaz'd. 'Th' immortal Sire, indulgent to his child, Bow'd his ambrosial locks, and Heav'n relenting, smil'd.

Of the great superiority of poetic to actual picture, this passage is one of the countless proofs, perceived by every reader who has power to meet the ideas of the Bard. Suppose the subject of this little fable to be engraven, or painted with the utmost excellence, yet the exquisitely natural action of the infant god shaking his 
fingers, and laughing and stamping, from that degree of pain experienced on slightly touching an ignited substance; the scattering over the floor the broken darts and arrows of the lightning; the alarmed deities retreating, and the indulgent nod and increasing smile of Jupiter, are all progressive circumstances which genius may paint on the imagination, but not on the canvass.

The Goddess next adverts to the influence of her nymphs on animal circulation, from the theory of the phosphoric acid colouring and warming the blood, and hence becoming an indispensable ingredient in vital formation

From the crown'd forehead to the prostrate weed.

This theory is illustrated by the noble fable of Eros, or Divine Love, issuing from the great egg of night, floating in chaos; but surely the image of this celestial love is too gay for the sublimity of its birth; " gaudy wings, soft smiles, golden curls, and silver darts," might suit the cyprian but not the hieroglyphic Cupid.

\section{........ Higher far of him}

And with mysterious reverence we deem.

Milton. 
Her Nymphs thus eulogized,

The Goddess paus'd, admir'd, with conscious pride,

Th' effulgent legions marshall'd by her side,

Forms spher'd in fire, with trembling light array'd,

Ens without weight, and substance without shade.

It may be observed of the two last lines that the imagination, which could with such appropriate and novel beauty invest its ideal personages, cannot be too highly appreciated, and we might as well disdain the sun for often dazzling us with excess of splendour, as to suffer the occasional redundance of ornament in this extraordinary work, to make us cold and insensible to its original, bold, and, in their class, peerless excellencies.

The use of words entirely Latin has been objected to this poem, as ens for liffe, in the last verse of the above quotation. Niceness of ear probably induced its substitution, and that from the proximity of the word light in the preceding line, which would have been of too similar sound to life, had life been used instead of its Latin synonism, ens.

The Botanic Gueen now proceeds to appoint the nymphs of fire their tasks. She bids them awaken the west wind, chafe his wan cheeks, and 
wring the rain-drops from his hair ; bids them blaze around the frosted rills, and stagnant waters, and charm the Naiad from her silent cave, where she sits enshrined in ice, clasping her empty urns. She is compared to Niobe.

Our poet seems to have forgotten himself in thus throwing the year back into the skirts of winter; since, in opening this Canto, he had described the spring in all her glory, when the Botanic Queen descended, and the impersonized elements received her.

The nymphs are also commanded to assail the fiend of frost; to break his white towers and crystal mail; to drive him to Zembla, and chain him to the northern bear. A simile ensues, in which the grampus, and the scene of the whale fishery, in all the strength of poetic colouring, meets the attention of the reader.

Supposed infuence of the principle of internal heat in vegetation induces a command to these its agents to pour electric torrents from the deep wastes of earth, which may pierce the root, relax the fibres, and thaw the sap of plants, flowers, and trees. The asserted consequence of their obedience to this command produces a noble sketch of the umbrageous wilds of Canada. Their operations are oddly compared to the effects of the sympathetic inks and 
of a picture drawn in them; and a receipt to make them is given in a note.

The nymphs are now exhorted to quit the summer regions when the dog-star shall preside in them. Its often blighting infuence on the fruits of the earth is illustrated by an allusion to the fate of Semele. Then rises an iceland scene, and an astronomical personification. Look at it, courteous reader, and if with eyes of indifference, arraign the power of prejudice in thy mind, or suspect thy want. of taste for the higher orders of poetry.

There in her azure coif, and starry stole,

Grey Twilight sits, and rules the slumbering Pole;

Bends the pale moon-beam round the sparkling coast, And strews with livid hands eternal frost.

An agency of the ignited particles in creation, that of separating the ice-islands, fancifully induces a command from the Goddess, that her nymphs should float their brokcn masses of ice to the torrid climates. It is adomed with the scripture incident, Eijah on mount Carmel, invoking fire from heaven, and the incident is given with all the Darwinian power.

This Canto terminates with the obedience of the nymphs, and a simile for their departure. They start from the soil, and wing their duteous flight. 
While vaulted skies, with streams of transient rays, Shine as they pass, and earth and ocean blaze.

A comparative description of the fire-works exhibited in great cities for the return of peace and liberty, after the cruel oppressions of war, is of the most accurate precision; but it is faulty as a simile, from its extreme inferiority to the imaginary objects which it is meant to illustrate. The nymphs of fire flying on their appointed errands, in every direction, illuminating, with evanescent flashes, the whole horizon, the sea, and the land, is so grand an idea, that the wheels, the dragons, the serpents, the mock stars, and suns, of that ever childish exhibition, become ludicrous, as succeeding to a picture of such gay sublimity; for sublimity is not always confined to sombre objects. Proofs that it is not, are found in the Paradise Lost. When Adam observes to Eve, on the approach of the angel Michael, that the glorious shape seems another morning rising on mid-noon, the idea is no less sublime than it is gay.

This apprehended injudiciousness of the firework simile suggests the remark, that a few such erratic luxuriances of a picturesque fancy, together with the peculiar construction of the Darwinian verse, and its lavish personification, enabled an 21 
highly ingenious satirist to burlesque the Loves of the Plants, by the Loves of the Triangles. Eminently fortunate for its purpose was the thought of transforming cubes, and cones, and cylinders, and other technical terms of mathematic and mechanic science, into nymphs and swains, enamoured of each other. The verse of this ironical poem is not only Darwinian, but it is beautifuliy Darwinian. The very slightly allusive power of several of the similies in the Botanic Garden, is ridiculed with infinite subtleness and wit; while the little stories in this burlesque, so comic in their scantiness of resemblance, are very elegantly told. That brilliant satire amply refutes Lord Shaftesbury's system, that ridicule is the test of truth, and that it is impossible to ridicule with effect what is intrinsically excellent. The warmest admirers of Dr. Darwin's splendid poem, and of the ingenious theories, and stated experiments of the notes, must yet be amused with such grotesque imitation of each; just as they are diverted with the burlesque, in the Critic, of the death of Hotspur, and of Eve's beautiful protest to Adam,

Sweet is the breath of morn, \&x.

On the subject of this satire, Dr. Darwin wantcd presence of mind. Instead of pretending, as he did, never to have scen or heard of the Loves of the 
Triangles, when questioned on the subject, he should voluntarily have mentioned that satire every where, and praised its wit and ingenuity. He ought to have triumphed in a just consciousness, that his poem could lose none of its charms with the few, whose praise is fame, by the artful resemblance of this false Florimel; secure that its mock graces, brilliant as they are, would soon melt away, like the Nymph of Snow in the Fairie Queen, while the genuine charms of his muse must endure so long as the English language shall exist; nay, should. that perish, translation would preserve the Botanic Garden as one of its gems; if not in original brightness, would at least retain all that host of beauties which do not depend upon the perhaps intransfusible felicities of verbal expression. The lavish mag. nificence of the imagery in this work, genius alone, bold, original, creative, and fertile in the extreme, could have produced. Its profusion may cloy the fastidious, its splendour may dazzle the poetically weak of sight; but still it is the result of that power, which Shakspeare characterises when he says,

The Poet's eye in a fine phrenzy rolling,

Doth glance from heaven to earth, from earth to heaven,

And as imagination bodies forth

The form of things unknown, the Poet's pen

Turns them to shape, and gives to airy nothing

A local habitation and a name. 
Opens with the charge of the Botanic Queen to her Gnomes, who are here restored to that benevolent character allotted to them by Rosicrusius, and which, to suit his purpose, Pope rendered malignant, in the Rape of the Lock. She addresses them as ministrant spirits to subterranean vegetation, and spectators of all the astronomic and terraqueous wonders of creation; of the Sun exploding our planet, the earth, from his crater.

Except to introduce an extremely fine description of the sun's signs in the zodiac, it would be difficult to guess why the Gnomes should be supposed to have pursued the flying sphere, and encircled the year's starry girdle. These should seem employments better suited to the allotted nature of the Nymphs of Ignition, or at least of the Sylphs, than of these their subterranean sisters. The epithet ardent, " your ardent troops," is a seldomfound instance of inaccuracy in this poem, corrected and polished with such elaborate care; eager, active, any thing rather than an adjective metaphorically taken from fire, the assigned element of the nymphs recently dismissed.

Next rises the golden age, and Earth is invested with Edenic privileges and exemptions. 
We are told, in a note, that there is an ancient gem, representing. Venus rising out of the sea, supported by two Tritons; that the allegory was originally an hieroglyphic picture, before letters were invented, descriptive of the formation of the earth from the ocean. The poet takes this opportunity of presenting to his readers the most beautiful portrait of Venus, first emerging from her parent deep, that has been given by any Bard, ancient or modern; and its features are unborrowed as they are peerless. She has about her the traces of the humid element, from which she rises, and they increase her general loveliness and grace; wringing, with rosy fingers, her golden tresses, as they hang uncurled around her fair brows, while bright drops of water roll from her lifted arms, wander round her neck, stand in pearls upon her polished shoulders and back, and star with glittering brine her whole lucid form. Thus the Darwinian Venus,

O'er the smooth surge, on silver sandals stood, And look'd enchantment on the dazzled flood.

The first terrestrial volcano is next described; an earthquake of incalculable magnitude, producing continents and islands on the before 
united and level earth, with separating oceans rolling between them. The birth of the Moon is now represented as thrown from the Earth near the south-pole, in consequence of this primal convulsion, by the explosion of water, or other vapors of greater power. The lunar birth is thus beautifully presented to the eye,

When rose the continents and sunk the main, And Earth's huge sphere, exploding, burst in twain; Gnomes, how you gaz'd, when from her wounded side, Where now the South-sea rolls its waste of tide, Rose, on swift wheels, the Moon's refulgent car, Circling the solar orb, a sister star ; Dimpled with vales, with shining hills emboss'd, And roll'd round Earth her airless realms of frost.

The difficulty of introducing these charming images any other way than by reminding the Gnomes of what they are supposed to have seen, gives us, in this address, the noun personal in apostrophe, with a frequency which, far from. being graceful, becomes almost ludicrous; as, "Gnomes, how you gaz'd!" Scc.... " Gnomes, " how you shriek'd!"... " Gnomes how you trembled"'... but infinite is the poetic fancy with which the hypothesis is maintained, of the earth 
being struck from the crater of the sun, and the moon from the first terrestrial volcano.

The Goddess now reminds her subterranean hand-maids of their assistance in having formed into marble and other petrific substances, the dissolving shells which covered the prominent parts of the earth, thrown up from her occean in that first convulsion, by sub-marine fires. Sculpture is here introduced, and poetic casts of the famous, ancient statues, the Hercules, Antinous, Apollo, and Venus, rise from the page. Roubilliac, unquestionably the first statuary of the modern world, is praised with enthusiasm; and Mrs. Damer, the ingenious mistress of the chisel, with delight.

To the Gnomes is next imputed the power of extracting the saline particles from different kinds of earths; from prostrate woods, and from morasses; and this introduces the description of a town in the immense salt-mines of Poland. With his peculiar ingenuity, this Bard of Fancy shows us the saline city; and that, and the statue supposed to be Lot's wife, the river and temple, gleam and sparkle on the imagmation of every reader who has imagination. To those who have it not, the magnificent pageantries of this poem will pass unrefected, unimpressive, 
And, like the baseless fabric of a vision,

Leave not a wreck behind.

Personification is surely carried too far when, in the next passage, azotic gas is made the lover of the virgin air, and fire transformed into a jealous rival, indignant of the treacherous courtship. The trio are compared to Mars, Venus, and Vulcan, and the Homeric tale, of the enmeshed pair, is told again. The mechanism of the net; the struggles of the guilty goddess to escape; her impatient exhortations to her nymphs, to disunite the links of the iron net-work; her efforts to conceal her beauties from the surrounding deities, have all that truth to nature with which criticism has justly observed Shakspear draws the manners of hisim aginary beings. With much more of that appropriate verity has Darwin told this story than Homer, and not more voluptuously. This is the only passage in the Botanic Garden which can justly be taxed with voluptuousnes, and with Homer its author shares the censure. Homer, whose morality has been so loudly, but so partially applauded, since his deities are all either libertine or unjust; and of his heroes, only one is in himself a virtuous man, and he defends the cause of his guilty brother, and doesnotonce urge the restoration of the stolen wire to her injured husband, an atonement not 
only in itself due, but which must have raised the siege, saved the city, and spared immense effusion of human blood. The story, if really founded on historic circumstances, might not have authorised the restoration of Helen, but it was in the poet's power to have made Hector urge it.

If the Homeric fable of Mars and Venus, in Vulcan's net, repeated by Darwin with new circumstances, more picturesque, not more indelicate, forms one somewhat licentious passage in the Botanic Garden, the Iliad contains several which are equally voluptuous, even after Pope has chastened them. As to the amours of the Plants and Flowers, it is a burlesque upon morality to make them responsible at its tribunal. The floral harems do not form an imaghinary but a real system, which philo. sophy has discovered, and with which poetry sports. The impurity is in the imagination of the rearler, not on the pages of the poet, when the Botanic Garden is considered on the whole, as an immodest composition.

From the net of Vulcan, and the lovers it entangles, the poet lcads us to his forge, after the mention of iron, as produced by the decomposition of vegetable bodies. 'To perceive the strength and truth of the Forge-picture, no power of imagination, on the part of the reader, is necessary; memo- 
ry is sufficient. Who has not seen a blacksmith's shop, and heard its din? Here it blazes and resounds on the page. The formation of magnetic bars ensues. Though the power of the magnet has been known and applied to use from very early times, yet the poet imputes these artificial magnets to their last improver, the personal friend of his youth, Mr. Mitchell, mentioned early in these memoirs. Of Mr. Michell's process in this improvement Dr. Darwin has formed another poetic description, so distinct that the operation may be performed from perusing it attentively.

And now we meet an animated apostrophe to Steel, praising its use in navigation, agriculture, and var. This applausive address is one of the grandest in the poem, where so many are grand. What has poctry more noble than these first six lines of that eulogium?

Hail adamantine Steel! magnetic Lord,

King of the prow, the ploughshare, and the sword!

'True to the pole, by thee the pilot guides

His steady course amid the struggling tides!

Braves with broad sail, th' immeasurable sea,

Cleaves the dark air, and asks no star but thee!

A description of Gems succeeds to that apostrophe, as a work of the Gnomes, by whom, from marine acids mixed with the shells of marine ani- 
mals, and of calcareous, and argillaceous earths, they are here supposed to be, from time to time, produced. These natural transformations are comparatively illustrated by those of Ovidian fable; and Proteus-gallantries are retold even more beautifully than Ovid has told them, particularly the story of Europa. It is here beyond all possible transcendence, exquisite, and it closes with a spirited compliment to the natives of Europe.

Returning to the subject, the Goddess reminds her Gnomes of having seen the subterranean volcanos forming the various species of clay; from the porcelain of China, and of ancient Etruria, to those used in the beautiful productions of its modern namesake, brought to so much perfection by the late Mr. Wedgewood. The mechanism of the porcelain of China, with its ungraceful forms and gaudy ornaments, rises on the page. The superiority, in the two last circumstances, of our English Etruria, is asserted, as producing " uncopied beauty and ideal grace ;" and its mechanism is also given, but in terms so technical as to spoil the harmony of the verse in that passage. Satire has caught hold of the seldom harshness, triumphantly displaying it in the Loves of the Triangles.

Mr. Wedgewood is addressed as at once the friend of art and virtue. His medallion of the Negroslave in chains, imploring mercy, is mentioned as 
reproaching our great national sin against justice and mercy, so long resisting the admonitions of benevolence and piety, in the senate; also another medallion of Hope, attended by Peace, and Art, and Labour. "It was made of clay from Botany "Bay, and many of them were sent thither, to "show the inhabitants what their materials would " do, and to encourage their industry." The emblematic figures on the Portland Vase, so finely imitated in our new Etruria, next appear in all the charms of poetry, while the truth of their ingenious construction is supported in the notes with wonderful learning and precision, so as to leave no doubt on the unprejudiced mind, that the Bard of Linnæus has explained their real design. This address to Mr. Wedgewood closes with the asserted immortality of his productions.

Coal, Jet, and Amber, are next impersonized, an individual for the species. The latter is placed on his " electric throne," as a meterial, the natural properties of which were the source of the disccveries in electricity, and from which the name of that branch of modem science is derived, electron being the Greek word for amber. Led by its phosphoric light, Dr. Franklin comes forward in the act of disarming the lightning of its dire effects, by his electrical rods, his infuence in procuring the freedom of America is applauded with much poctic 
imagery. The short-lived freedom of Ireland in her acquirement of self-legislation, is allegorized by " the warrior Liberty, helming his course to her "shores."

Another bold figure of Liberty succeeds, presented as a giant form, slumbering within the iron cage and marble walls of the French Bastile, unconscious of his chains till, touched by the patriot flame, he rends his fimsy bonds, lifts his colossal form, and rears his hundred arms' over his foes; calls to the good and brave of every country, with a voice that echoes like the thunder of heaven, to the polar extremities;

Gives to the winds his banner broad unfurl'd, And gathers in its shade the living world!

This sublime sally of a too-confiding imagination has made the poet and his work countless foes. They triumph over him on a result so contrary; on the mortal wounds given by French crimes to real liberty. They forget, or choose to forget, that this part of the poem (though published after the other) appeared in 1791, antecedent to the dire regicide, and to all those unprecedented scenes of sanguinary cruelty inflicted on France by three of her republican tyrants, compared to whom the most remorseless of her monarchs was mild and merciful. 
The Botanic Queen now remind's her Gnomes of the means they had used to produce metallic substances; and, from the mention of silver and gold, she starts into a spirited and noble exclamation over the cruelties committed by catholic superstition in the East and West Indies; and from them she turns with equal indignation, to the slave trade, that plague-spot on the reputation of our national humanity! that crying sin in the practice of our national religion! Greatly is it to the honor of our English poets, within the last twenty years, that, with very few exceptions, the best and most highlygifted of them have fought their way to fame beneath the banners of Freedom and Mercy, whose eternal nature no national or individual abuse, no hypocritical assumption, can change.

These instances of unchristian barbarity lead to the story of the cruel and impious Cambyses on his march to subdue Ethiopia, after having destroyed the temples and devasted the country of Thebes, and massacred its inhabitants. The fate of that army is described which he sent to plunder the temple of Jupiter, and which perished in the desert overwhelmed by sand. The Gnomes are considered as ministers of that just vengeance, and of the famine by which it was preceded; and this, by withholding the dews, and blasting vegetation, and by summoning the whilwinds which cause 
the fatal rise of the sand-tornados. The successive horrors that overtook this army are depicted with the highest interest and grandeur. They rise in climax till the final overwhelming is thus brought to the shuddering imagination of the reader,

\section{............ awhile the living hill}

Heav'd with convulsive throes,.....and all was still!

language has nothing of more genuine sublimity.

Turning from this dread tragedy, the Botanic Queen assumes a livelier strain, and compares her little ministers to the planets in an orrery. That beautiful machine is described with its fairy-mimicry of the stellar evolutions. She exhorts her nymphs to the practice of several benevolent operations, guarding against the mischiefs of elementary excess. Hannibal's renowned march over the Alps, against tyrannic Rome, and the supposed means by which he facilitated his progress, are held up to thcir imitation. To this succeeds an exhortation to feed the embryons, and forward the parturition of trees, plants, and flowers. For those offices a medical simile occurs, and afterwards a scripture story is told, Peter released from prison by an angel, and to that angel the illustriously benevolent Howard is compared. 
Imputed assistance, on the part of these subterranean nymphs, in the chemical decomposition of animal and vegetable substances, introduces the ancient fable of the slaughtered, buried, and assurgent Adonis. His story is told with not less added poetic excellence than, with accession of personal beauty, he is said to have arisen from the dark mansions of Proserpine, and to have returned to Venus. Dr. Darwin's reasons, given in the note to this passage, for rejecting former interpretations of that allegory, are convincing ; and his substituted solution is not only highly ingenious, but deeply philosophic; and good sense sanctions the conjecture.

This fable closes the address of the Goddess to her Gnomes. Their elfin flight on their appointed errands, is described with playful elegance, and compared to the successive shadows that pass over a sunny vale beneath the light clouds. With that comparison the second Canto terminates. If the Gnomes make their exit with less poetic splendor than their predecessors, it must be considered that the Nymphs of Fire are personages of more intrinsic dignity. 
Opens with a charge to the Water Nymphs, and we are told that the Goddess gives it in tones so sweet and sonorous as to shake the wrinkling fountains, curl the deep wells, rimple the lakes, and thrill the rivers.

The three first words selected to express the different kind of actual vibration on the fountains, wells, and lakes, are instances of that nice discrimination which imparts so much vitality to verse, and gives back to the reader his faded recollection of the objects of nature in their comparative distinctions. Though he may have viewed them often with unexamining eyes, yct no sooner do they arise before him on the poetic page than he recognises their truth with the thrill of delight; for who that looks into the records of the Muses, however insensible to the creations of Fancy, can view without pleasure the faithfully reflected image of naturre in the subtle variety of her lineaments.

Thick as the dews which deck the morning flowers,

Or rain-drops twinkling in the sun-bright showers,

Fair nymphs, emerging in pellucid bands,

Rise as she turns, and whitten all the lands.

Their mistress tells them also, how much she is conscious of their power and use, in the forma- 
tion, substance, and protection of the vegetable world. In the exordium of this charge we meet a couplet rivalling in picturesque beauty the lines in Collins' charming, though rhymeless Ode to Evening, when he tells the grey-stoled personage, that from his hut on the mountain side, he loves to contemplate, in a showery twilight,

The hamlets brown, and dim-discover'd spires,

And hear their simple bells, and mark o'er all

Her dewy fingers draw

The gradual, dusky veil.

The Botanic Queen says to her aqueous ministry in these rival lines,

Your lucid hands condense, with fingers chill, The blue mist hovering round the gelid hill.

This charge has one harsh line; thus,

And as below she braids her hyaline hair.

The employment gentle, the attitude graceful, that harshness of measure which is often skilful when used to express violent exertion, is here censurable.

These new vicegerçnts are praised as feeding the harvest, filing the wide-ribbed arch with hur- 
rying torrents, to assist the operation of the mill and the progress of the barge, and leading the reftuent water to its parent main. These operations on the water induce a simile for the progressive and returning course of the blood. The purpureal tint it gives to the fair complexion of youthful beauty; the warm glow to her hair, the laugh of health to her lip, and its lightning to her eyes, form a lovely picture in this simile; and it closes with a medical observation in a fine poetic figure.

Just discernment will not cease to admire the facile success and artful grace with which this poet subdues the difficulty of rendering all sorts of science subservient to the purposes of high heroic verse; or to observe how seldom even the most technical terms diminish the harmony of his measure, or the elegance of his imagery.

Mighty sway is attributed to the aqueous ladies over those realms of scale and shell, which are covered by the sea; and they are considered as architects of the pearly palaces of the fish. The modern experiment of smoothing rough waves with oil, is considered as their suggestion; also various sub-marine and benevolent infuences. To them the birth of rivers, from the Alpine snows. The Danube, the Rhine, and the Tiber, are mentioned; the last as flowing through his degenerate realms 
with diminished waters. The features of that degeneracy are marked; the race of patriots, heroes, and legislators, long since become singers, dancers, and monks; and the passage concludes with this sublime picture of the present state of that long-renowned river.

Parts with chill stream, the dim religious bower,

Time-moulder'd bastion, and dismantled tower;

By alter'd fanes, and nameless villas glides,

And classic domes, that tremble on his sides;

Sighs o'er each broken urn and yawning tomb,

And mourns the fall of Liberty and Rome.

Rivers being the subject, the Nile and its annual overflow, gives rise to grand allegoric imagery, and to nobly-imagined scenes. That overflow is ascribed to the monsoon winds, which deluge Nubia and Abyssinia with rain.

Sailing in air, when dark Monsoon enshrouds

His tropic mountains in a night of clouds;

Or, drawn by whirlwinds, from the Line returns,

And showers on Afric all his thousand urns;

High o'er his head the beams of Sirus glow;

And, dog of Nile, Anubis barks below.

Nymphs, you from cliff to cliff attendant guide,

In headlong cataracts, the impetuous tide;

Or lead o'er wastes of Abyssinian sands

The bright expanse to Egypt's showerless lands. 
Her towns, her temples, and sultry plains are contrasted with a sublime description of Hecla and its burning mountain. Its column of boiling water is transformed into a malignant sorceress, whose baleful spells had been broken by the power of these benevolent Naiads.

The hypothesis, that warm salubrious springs are produced by steam arising from water falling on subterranean fires, and that this steam is condensed between the strata of incumbent mountains, and coliected into springs, occasions a sportive address to Bux:on. It is succeeded by an elegant compliment to the Duchess of Devonshire, leading a train of graces from Chatsworth to that tepid fountain. From the epithet fairy given to legions, we should suppose these graces a part of the machinery of the poet; but, as the passage proceeds, it describes beautiful young women bathing with such exquisite precision, that the scene of action considered, it becomes impossible to contemplate them as ideal personages, especially as the last couplet is utterly at war with aerial substance; thus,

Round each fair nymph her dropping mantle clings, And Loves emerging shake their showery wings.

The loves, which are indisputably machinery, confuse the picture, if the nymphs also are of that 
species. The expression fairy legions, is to be regretted; it renders the lively and lovely description amenable to Dr. Johnson's censure of a passage in one of our poets, "that it is metaphoric in " one point of view, and literal in another."

The Duke of Devonshire's public spirit and architectural taste, next become the theme, and they involve a charming picture of the Crescent, that gem of Grecian art in Britain; and of the new plantations which surround it. Derbyshire stone has an amber tint, and hence the Buxton Crescent rises a golden palace in the desert.

The Goddess next congratulates her Water Nymphs on having celebrated the odd nuptials of pure air and inflammable gas. We had heard of their courtship earlier in the poem. That courtship, and this their marriage, forms one of the wildest cxtravagances of the work; but the Homeric fable, which illustrates the airy bride and groom, is charming in the first degree. Juno, attired by Venus to captivate Jove. With the most luxuriant fancy, and with new circumstances, this little drama rises again on the Darwinian page. It will not lose, but gain in a just estimation of poetic merit, by comparisen with the translations, by Cowper and Pope, of this celebrated part of the Greek poet's machinery. Let them be'compared, and first Cowper's literal translation, first edition. 
First, she lav'd all o'er

Her beauteous body with ambrosial lymph;

Then polish'd it with richest oil divine,

Of boundless fragrance. Oil, that in the courts

Eternal only shaken through the skies

- Breath'd odours, and through all the distant earth*.

Her whole fair body with these sweets beclew'd,

She pass'd the comb through her ambrosial hair,

And braided her light locks streaming profuse

From her immortal brows; with golden studs

She made her gorgeous mantle fast before;

Etherial texture, labour of the hands

Of Pallas, beautified with various arts,

And brac'd it with a zone, fring'd all around

An hundred fold; her pendants, triple gemm'd,

Luminous, graceful in her ears she hungt.

And covering all her glories with a veil

Sun-bright, new-woven, bound to her fair feet

Her sandals elegant. Thus full attir'd

In all her ormaments, she issued forth,

And beck'ning Venus from the other powers

Of Heav'n apart, the goddess thus bespake.

\section{Pope's translation of the same passage.}

Here first she bathes, and round her body pours

Soft oils of fragrance, and ambrosial showers.

The winds perfum'd, the balmy gale convey

Through heav'n, through earth, and all th' aerial way.

Spirit divine! whose exhalation greets

The sense of Gods with more than mortal sweets.

* Obscure and very awkward expression. $\uparrow$ Mcst unpoetic. 
Thus, while she breath'd of heav'n, with decent pride

Her artful hands the radiant tresses tied;

Part o'er her head in shining ringlets roll'd,

Part o'er her shoulders wav'd like melted gold;

Around her neck a heavenly mantle ftow'd

That rich with Pallas' labour'd colours glow'd;

Large clasps of gold the foldings gather'd round;

A golden zone her swelling bosom bound;

Far-beaming pendants tremble in her car,

Each gem illumin'd with a triple star;

Then o'er her head she casts a veil more white

Than new fall'n snow, and dazzling as the light;

Last, her fair feet celestial sandals grace,

Thus issuing radiant, with majestic pace,

Forth from the dome th' imperial Goddess moves,

$\Lambda$ nd calls the mnther of the Smiles and Loves.

- Pope has shewn better taste in female dress than his master. A zone with an hundred folds of fringe upon it, must be a very heavy and inelegant ornament. The zone of plain gold, substituted by the rhyme translator, is grander and more graceful as well as more simple.

Darwin, who gives this fable after his own manner, tells us, that Venus not only lent the cestus, but attired the goddess herself; and passing over the classic ceremony of the bath, and the operation of the oils, which perhaps he thought too Hottentotish, he describes more concisely, yet not less brilliantly, this magnificent labour of the toilette; thus, 
So, rob'd by Beauty's Queen, with softer charms,

Saturnia woo'd the Thunderer to her arms;

O'cr her fair limbs a veil of light she spread, And bound a starry diadem on her head;

Long braids of pearls her golden tresses grac'd,

And the charm'd cestus sparkled round her waist.

The cestus is here a visible and brilliant ornament, instead of being; as Homer afterwards tells us, hid in Juno's bosom. Pope, in a note to this passage, observes, that, by this disposal, the poet meant to convey an idea of the matron-like modesty of Juno, who conceals what is to render her engaging; while Venus, wearing the cestus in open sight, ostentatiously displays the means by which she captivates; but this sort of lesser morality belonged not to the times in which Homer lived; neither is peculiar delicacy at all characteristic of the Juno he has drawn. His more probable reason for making: her hide this ornamental spell, was the danger that Jupiter, if he saw the borrowed zone, so often scen on the person of his daughter, would know it, and conscious of its power to excite passion, would have been aware of the design of his wife, and either not allowed of the interview, or disarmed the girdle of its magic. Supreme wisdom must have foiled discovered art. Neither of these suppo- 
sitions occurred to Dr. Darwin, or perhaps his Juno also had hidden her gay talisman.

Homer expressly says, Juno did not take her chariot on this conjugal visit; but Darwin allots her that mode of conveyance, and the change enabled him to assign to the Empress of Heaven her due pomp and stately retinue. Upon this imperial and celestial equipage the modern poet has lavished all the splendours of his imagination. Cupid is the charioteer, and Zephyr flies before, showering roses from his wings; Naiads and Dryads, Fawns and Wood-Boys are in the train. The reader is empowered, by distinctness of poetic description, to pursue the chariot with his eye, as its ascends the steeps of Ida, now lost in its thick woods, now infull blaze, winding around its rocks.

But surely there is an error of judgment in making Cupid wing an arrow to the breast of Jove, as the retinue approaches, since that mode of awakening the passions of Jupiter for his queen, renders the charmed cestus a superfluous gift. And again, this gay car is represented as drawn by doves; from which it should seem that Venus had lent her equipage, as well as her girdle, on that occasion.

The address of the God to his Goddess is incomparably more elegant in the verse of 
Darwin than in the translation of Cowper, or eren of Pope. Thus says Cowper, with all that cramp literality which hobles through his version.

Soon he accosted her, and thus inquir'd:

" Juno, what region seeking, hast thou left

"' Th' Olympian summit, and hast here arriv'd

"With neither steeds nor chariot in thy train ?"

POPE.

Fix'd on her eyes he fed his eager look,

Then press'd her hand, and thus transported spoke :

"Why comes my Goddess from th' etherial sky,

"And not her steeds, and flaming chariot nigh ?"

\section{DARWIN.}

Pierc'd on his throne, the starting Thund'rer turns,

Melts with soft sighs, with kindling rapture burns;

Clasps her fair hand, and eyes, in fond amaze,

The bright Intruder with enamour'd gaze:

"And leaves my Goddess, like a blooming bride,

" The fanes of Argos, for the rocks of Ide ;

"Her gorgeous palaces, and amaranth bowers,

"For cliff-top'd mountains, and aerial towers?"

But to resume the Botanic Goddess and her enumeration of the interesting employments of her third class of Nymphs; their disposal of all those bright waters which make Britain irriguous, verdant, and fertile. We find this beautiful couplet in the course of the passage : 
You, with nice ear, in tiptoe trains pervade

Dim walks of morn,* or evening's silent shade.

She then places them on the shore, listening to its pausing murmurs, and to the song of the Nereid, as on her playful sea-horse she glides over the twilight-main. Another exquisite picture arises, professedly from an antique gem. Great skill is shown in varying the attitude, appearance, and employments of this beautiful SeaNymph, on her voyage, from those of Europa, crossing the sea on her bull, in the preceding Canto. Her's is a clay, and this is a night voyage. Europa draws up her feet beneath her robe, fearful of touching the water; the secure Nereid drops them carelessly down. Europa clings timidly round the neck of her Taurus, and rests her cheek upon "the curls of his forehead, while her mantle floats unheeded on the breeze. The Nereid has no apprehension; she and her steed are both in their element. She gives him the rein, lifts her eyes to the evening star, and sings the birth of Venus. She restrains her arching veil, with her hands, from floating on the gales of night, while the mantle of Europa was abandoned to the day-breeze. The Nereic is without fear, and therefore attends to the preservation of her iress; Europa is somewhat 
frightened, andtherefore pays no attention to her's. These differences, however apparently, are not really trivial. The mere versifier knows not how to create them. The Poet knows their importance; how much they will inspirit his portraits, and dis. tinguish them from each other. In the progress of this episode the Nereid looses her veil (we may conclude the wind had fallen) and we meet the following description of a very graceful operation, that of a lovely female combing her lavish tresses:

O'er her fair brow her pearly comb unfurls

Her beryl locks, and parts the waving curls;

Each tangled braid, with glist'ning teeth unbinds,

And with the floating treasure musks the winds.

This is not a repetition of the employment of the dew-born Venus, in the second Canto. She had recently emerged, and therefore her hair must necessarily hang uncurled, and she is in the attitude of wrinģing the water from her golden tresses; - than which no position can be more favourable to female symmetry.

Doctor Darwin's poem paints every attitude and employment which, in either sex, can be rendered elegant. No author ever had a mind more keenly awakened to grace in all its varieties, or could more exquisitely paint it. 
That perception, and that talent, the, in his class of composition, peerless Richardson possessed in an equal degree. No prose-writer ever was, or perhaps ever will be, so great a painter; and to that power what a constellation of other endowments contributed to immortalize the pages of Clarissa and Grandison! Novels no longer, but English Classics, translated into every European language, and in all foreign countries considered as some of the noblest efforts of British Genius.

But the Darwinian Nereid has been left a little before her time; other circumstances attend her, too poetic to remain unnoticed. Her song "thrills the waves;" and the shadowy Forms of Night gleam on the margin of the shore, "with pointed ears," to denote the act of listening. Perhans that characteristic had been better omitted, since it belongs to brute, not to human animals, and is at war with the imaginary grace of these twilight forms. The Moon pauses, and the Stars shoot from their spheres to listen. That last circumstance is evidently from Shakspear's allegory in The Midsummer Night's Dream, alluding to the conspiracies formed in favour of the imprisoned Queen of Scotland, by the Duke of Norfolk, and other noblemen of the court of Elizabeth. This is the allegory: 
I saw a Mermaid on a Dolphin's back

Uttering such clulcet and harmonious sounds,

That the rude sea grew civil at her song;

And certain stars shot madly from their spheres,

To hear the Sea-Maid's music.

That he might guard against the displeasure of Elizabeth for this sally, it is immediately followed by as high an allegoric compliment paid to herself.

On the poet's dișmissal uf the Nereid, the death of Mrs. French of Derby, is introduced as a subject of sorrow to the Water-Nymphs of its river. The picture of Milcena, is very lovely, strajing with her infants on the banks of the Derwent, and pondering, with scientific eye, the insects and plants on the shores of that stream. There is a tender strain of morality in this passage; but the annexed epitaph on Mrs. French, however beautiful as poetry, is by no means fit for its originally purposed situation, a tombstone in the great church at Derby. The author of these memoirs is ignorant whether, or not, it is there inscribed. "Clouds " of silver, and Beauty pleading for he" husband's " errors at the throne of Crod," may form a very poetical, but it is a very heathenish resurrection.

The mention of Brindley, the father of commercial Canals, has propriety as well as happiness. Similitude for their course, to the sinuous track 
of a serpent, produces a fine picture of a gliding animal of that species, and it is succeeded by these supremely happy lines:

So, with strong arm, immortal Brindley leads

His long canals, and parts the velvet meads;

Winding in lucid lines, the watery mass

Mines the firm rock, or loads the deep morass;

With rising locks a thousand hills alarms,

Flings o'er a thousand streams its silver arms;

Feeds the long vale, the nodding woodland laves,

And Plenty, Arts, and Commerce, freight the waves.

Nymphs, who crewhile on Brindley's early bier,

On snow-rwhite bosoms shower'd th' incessant tear,

Adorn his tomb !....Ol, raise the marble bust,

Proclaim his honors, and protect his dust !

With urns inverted, round the sacred shrine

Their ozier wreaths let weeping Naiads twine,

While on the top mechanic Genius stands,

Counts the fleet waves, and balances the sands!

There is a notc to this passage, which urges the duty of erecting a monument to Brindley in Lichnied Cathedral. Certainly it would be to the credit of those who should subscribe to raise it, since the county of Stafiord has been so materially benefited by his successful plans; but in the above euloginm, Dr. Darwin has given him a more enduring memorial than stone or marble could bestow. 
The mechanism of the pump is next described with curious ingenuity. Common as is the machine, it is not unworthy of a place in this splendid. composition, as being, after the sinking of wells, the earliest of those inventions, which, in situations of exterior aridness, gave ready accession to water. This familiar object is illustrated by a picture of Maternal Beauty administering sustenance to her infant. To that succeeds an energetic reproof, and pathetic admonition to mothers in afluent life, whom indolence or dissipation, seduces to the unnatural neglect of that delightful duty. For an infant slumbering on the maternal bosom which has nourished him, there is the following allegoric simile, of no common clegance:

Thus, charm'd to sweet repose, when twilight hours Shed their soft influence on celestial bowers, The cherub, Innocence, with smile divine, Shuts his white wings, and sleeps on Beauty's shrine.

The Ode to Morning, in Eifrida, contains a nearly resembling image; thus,

Away, ye Elves, away,

Shrink at ambrosial morning's living ray!

That living ray, whose power benign

Unfolds this scene of glory to our eye,

Where, thron'd in artless majesty,

The cherub Beauty sits on Nature's rustic shrine. 
Probably to the involuntary plagiarism of forgotten impression, we owe this sister-picture on the page of Dr. Darwin.

The use of water by the fire-engine next occurs. Poetry has nothing more sublime than this, the preceding picture of a Town on Fire:

From dome to dome when flames infuriate climb, Sweep the long street, invest the tower sublime;

Gild the tall vanes amid th' astonish'd night, And reddening heaven returns the sanguine light; While, with vast strides and bristling hair, aloof

Pale Danger glides along the falling roof;

And giant Terror, howling in amaze,

Moves his dark limbs across the lurid blaze;

Nymphs, you first taught the gelid waves to rise,

Hurl'd in resplendent arches to the skies;

In iron cells condens'd the airy spring,

And imp'd the torrent with unfailing wing;

On the fierce flame the shower impetuous falls, And sudden darkness shrouds the shatter'd walls; Steam, smoke, and dust, in blended volumes roll, And Night and Silcnce repossess the pole.

Dryden, in his Annus Mrabilis, has described the great fire in London. Some very fine lines oscur in that description, but it is prolix and fecble in comparison with the above.

The melancholy circumstances of the Woodmason finily, and that of Lakiy Molesworth, each 
of whom suffered dreadfully by fire, are next pourtrayed with much pathetic solemnity, and the $\mathrm{Wa}$ ter-Nymphs are reproached for not having prevented those evils.

After this mournful little drama, the Botanic Queen allots new tasks to these her hand-maids in the care of vegetation, and they are beautifully specified. To them succeeds an highly interesting picture of Sympathy in a female form, bending over a rock to assist the ship-wrecked mariners; she is shown afterwards as supporting feeble Age on her arm, pouring balm into the rounds of Sorrow; snatching the dagger from Despair; lulling Envy to sleep, and while she reposes, stealing her envenomed arrows from her quiver. An animated eulogium on a benevolent young lady of Ireland, diversifies these commissions; also three of Hercules' labours. A flooded country is presented in the deluged Etolia; and the Water Fiend, that caused the inundation, and whom Hercules subdues a second time, when assuming the form of a snake, it attempts to escape from the hero. It is thus admirably pictured:

Then to a snake the finny Demon turn'd,

His lengthen'd form, with scales of silver burn'd;

Lash'd, with resistless sweep, his,dragon tail,

And shot meandering o'er th' affrighted plain. 
Perhaps the description of the Fiend's next transformation into a Bull, is not eminently judicious; the terms "silver hoofs," and "flowery "meadows," which might well have suited the gentle bull of Europa, are too nice and gay to harmonize well with the enraged monster, one of whose horns was torn off by Hercules. Of the habits and manners of that formidable Brute, when incenseç, a very inferior Poet, lately deceased, has given a more impressive picture. We sometimes find one or two good passages in the writings of ordinary versifiers. Sternhold's and Hopkins' nonsensical and vulgar translation of the Psalms, contain eight lines which Pope professed to envy. Though Hurdis was chosen Professor of Poetry in Oxford contrary to Pope's precept,

\section{Let such teach others who themselves excel.}

yet he has given a description of the only very ter. rific English animal, which, when weeded of a long interrupting digression in the middle of it, about a thunder-storm, forms the most natural portrait of a malicious Bull that can perhaps be found in any of our poets; thus, 
........... 'Tis pleasure, to approach,

And by the strong fence shielded, view secure

Thy terrors, Nature, in the savage Bull.

Soon as he marks me, the tyrant fierce,

To earth descends his head; hard breathe his lungs

Upon the dusty sod..... $\Lambda$ sulky leer

Gives double horror to the frowning curls

That wrap his forehead; and ere long is heard,

From the deep cavern of his lordly throat,

The growl insufferable.*... Tramples then

The surly Brute, impatient of disdain,

And spurns the soil with irritated hoof;

Himself inhaler of the dusty sod;

Himself insulted by the pebbly shower,

Which his vain fury raises. Nothing fear'd,

Let him, incens'd from agitated lungs

Blow his shrill trump acute till echo ring;

And witlı a leer of malice, steel away,

Assault and vengeance swearing ere be long!

The last command of the Botanic Goddess to her Water-Nymphs, enforces their cluties to plants and flowers; to render the vales irriguous, and to feed with their rills the foral and herbaceous roots. To the course of this moist nutriment through the vegetable fibres, is compared that of the chyle through the human frame; and to that, another simile succeeds. As the first is scientific, so is the second picturesque; it is a Turkish pilgrimage to Mecca, consisting of various caravans on their road

* Here comes in the impertinent thunder storm. 
ofer the sultry and sandy desert, and meeting with a pure rill, which, descending from distant rocks, had taken its course through the waste plain. The parched Travellers alight, kneel on the brink in grateful joy, and bending over it, assuage their thinst. This rill somewhat suddenly becomes a lake, and refects the eager and delighted multitude. With this litêle scene the commissions to the Water-Nymphs conclude, and their obedient fight is scarcely less poetically featured than that of the Nymphs of Fire. The similes, which illustrate the flight of the aqueous ministers, are the evolutions of the water-spider, and the exercise of skaiting amongst the natives of northern climates. The last is thus admirably described:

So where the North congeals his watery mass, Piles high his snows, and floors his seas with glass, While many a month, unknown to warmer rays, Marks its slow chronicle by lunar clays;

Stout youths and ruddy maids, a sporive train, Lcave the white soil and rush upon the main.

From isle to isle the moon bright squadrons stray, And win, in graceful curves their easy way:

On step alternate borne, with balance nice Hang o'er the gliding steel, and hiss along the ice. 
FOURTH AND LAST CANTO OF THE ECONOMY OF VEGETATION,

Consists of a charge to the Sylphs, as benevoient spirits, to protect the vegetable substances, after they had emerged to light and air ; to defend them from all the malignant operations of nature, and to cherish and assist the influence they may receive from all her vital and benign powers.

The deadly and salubrious winds; the volcanic and pestilential airs; the Tornado, cireadful to mariners, \&c. ; cvery thing here has animal life and consciousness. It was the author's plan, and he could not, at least in his own idea, depart from it with propriety. Hence, the Sylphs also are reminded of having presided at the nuptials of the purest of the Airs with Light. The passage which ushers in this whimsical marriage, is very beautiful, the expression, " simpering lips," excepted; but it was difficult to find variety of terms equally happy where the effect of pleasurable sensations on the countenance must so often be clescribed. From these aerial nuptials vital spirit is supposed to proceed, which pervades and animates all nature. The loves and marriage of Cupid and Psyche are presented, poetically pictured from the well-known gems. This life-infusing air is contrasted with the Syroc of Italy, and the Simoon of the African ciescrt. 
The last is presented as a Demon. Universal personification was the order of the Muse in this work, not to be infringed; else, when circumstances are in themselves sublime (and most things terrible in nature becomes sublime in poetry), they are more likely to be of diminished than increased force, by the addition of fabled endowment. A comparison between the Simoon described literally by Southey, in his Joan of Arc, and figuratively by Darwin, will perhaps evince the truth of this observation. The Botanic Queen says to her Sylphs,

Arrest Simoon amid his waste of sand, The poison'd javlin balanced in his hand!

Fierce on blue streams he rides the tainted air,

Points his keen eye, and waves his whistling hair ;

While as he turns the undulating soil

liolls its red waves, and billowy deserts boil.

This is a fine picture of the Demon of Pestilence. The speed of his approach is marked by the strong current of air in which he passed, and by the term whistling annexed to his hair. The winds have hitherto, almost exclusively possessed that term. Here transferred to the lifted hair of the Demon, it increases the terrific power of his ap. roach. But let the Simoon be viewed where its terrible graces are native, and no attempt made to highten them by allegory. 


\section{JOAN OF ARC, TENTH BOOK.}

............... Ominous fear

Seizes the traveller o'er the trackless sands, Who marks the dread Simoon across the waste Sweep its swift pestilence. To earth he falls, Nor dares give utterance to the inward prayer, Deeming the Genius of the desert breathes The purple blast of Death.

We are informed by travellers, that to inhale the least portion of this mephitic blast is fatal. They therefore fall on their faces, and hold their breath till it has passed over them.

But the Darwinian personification of the Tornado sublimely heightens the horror of that watery pest. It succeeds that of the Simoon ; and the Fog, invested with animality, forms an immediate and striking contrast to the preceding monsters. It is drawn with such singular felicity of imagination that there is no resisting the desire of quoting the passage here :

Sylphs, with light shafts, you pierce the drowsy Fog, That lingering slumbers on the sedge-wove bog; And with webb'd feet o'er midnight meadows creeps, Or flings his hairy limbs o'er stagnant deeps.

The benevolent little spirits are then exhorted to combat Contagion, stealing from charnel- 
vaults to bring death to the people. The plague, which in 1636 raged in Holland, is here introduced, with a beautiful story of faithful Love prevailing over the desire of self-preservation. A beautiful maid is first seized in a, till then, uninfected family. This admirable line denotes the dread of its other individuals to approach, assist, or comfort her,

And starting Friendship shunn'd her as she pass'd.

Perceiving herself deserted, and fearing to spread the infection amongst those she loved, she seeks the garden, determined to die there. Her betrothed lover hears of her situation, and pursues her thither; raises a tent; procures her food, covering, and medicines; binds her fevered brows, and strews aromatic herbs and fowers upon her pillow. He escapes the contagion himself, and restores his beloved mistress to health. The poet has very sweetly told this interesting tale; a single epithet is perhaps the only word it contains which could be altered to advantage. It is in the following line, 
The adjective bright is too gay for its situation; fair, or lov'd, would be more subdued, and in better keeping with the mournful tenderness of the narration.

Less bold, says the Poet, was Leander, eying, as he swam, the love-lighted tower. Less bold also, Tobias, instructed by an angel to drive away the demon from the fatal bride.

The Sylphs are now applauded by their Queen for having instructed Torricelli and Boyle, concerning the properties of air, its pressure and elasticity. 'The operations of the weather-glass and air pump are described with philosophic accuracy and poetic elegance. Young Rossiere's dire fate, precipitated from his flaming montgolfier, comes forward here, and is pictured with great poetic strength; nor is the illustration of that lamentable event, by the fable of Icarus, less happy in its novel and mournful graces; his faithless and scattered plumage dancing upon the wave; the Mermaids decking his watry tomb, strewing over his corse the pearly sea-flowers, and striking, in the coral towers, the pausing bell, which echoes through the caves of Ocean! Surely it is not possible to admire too fondly the beautiful and exhaustless varicties of this darling Bard of Fancy. 
Critics have asserted that the poetic mind has little efflorescence after middle life; that, however the judgment may strengthen, the vivid luxuriance of the imagination abates. Milton's Paradise Lost, Darwin's Botanic Garden, and Cowper's Task, each begun after life had many years declined from its meridian, confute the dogma. Dr. Johnson has combated its fallacy, and with more truth observed, that so long as the understanding retains its strength, the fancy, from time to time, acquires added vigor and new stores of imagery. Nor does the extreme poetic inferiority of the Paradise Regained to the Paradise Lost, at all clisprove the converse proposition. We are to look for that inferiority in the so much more restraining nature of the subject, for poetry, above all others, improper. Poetry! to whose very existence, if it is to deserve its name, an infinitely larger portion of inventive and figurative ornament is necessary than the hallowed sobriety of the New Testament and its mysteries, can admit without the most revolting impropriety. Its choice, as the theme of an Epic Poem, was a radical error, which necessarily involved those long trains of comparative prosaicism, over which we yawn, horvever sometimes awakened by noble passages to recognise strength, which, though seldom put forth, we feel to be un- 
diminished; tn discern some rays of light which, amidst their infrequency, we yet perceive to be unfaded.

Fresh commendation is next given to the Sylphs for their inspirations in the mind of Dr. Priestly, concerning his analysis of the atmosphere. The passage is most pociic, although purely chemical. Air calcining the phlogistic ores is termed the marriage of Ether with the Mine. These nuptials are illustrated by the retold story of Pluto and Proserpine. There is much propriety in this illustration, since Lord Bacon has explained that fable as an hieroglyphic allusion, to signify " the com" bination or marriage of etherial spirit with earthly " materials."

A whimsical possibility is next supposed; that Dr. Priestley's discoveries will hereafter enable adventurers to travel beneath the ocean in large inverted ships and diving baloons. A note to this passage asserts, that the expcriment was successfully made by a Frenchman, in the reign of James the First, and it states the particulars. A splendid sub-marine voyage next occurs. It is to the warm tropic seas and shadowy ice-isles of the polar regions, and to be performed by Britannia. Her tears are to flow as she passes over the sad and visible remains of ship-wrecked loyers, mercantile 
and scientific adventurers, particularly those of Day and Spalding, who each perished in their diving-bells. Here the deplored fate of Captain Pierce, his family and fellow-voyagers, thus forms a tragic drama:

Oft o'er their lovely dauglters, hapless Pierce!

Her sighs shall breathe, her sorrows dew their hearse.

With brow upturn'd to heaven, "We will not part,"

He cried, and clasp'd them to his aching heart,

Dash'd in dread conflict on the rocky grounds,

Crash the shock'd masts, the staggering wreck rebounds;

Through gaping seams the rushing deluge swims;

Chills their pale bosoms, bathes their shuddering limbs;

Climbs their white shoulders, buoys their streaming hair,

And the last sea-shriek bellows in the air.

Each, with loud sobs, their tender sire caress'd,

And gasping, strain'd him closer to her breast.

Stretch'd on one bier they sleep beneath the brine,

And their white bones with ivory arms entwine.

The third, fourth, and fifth, couplets of the above quotation, are extremely fine pictures, and "sound never echoed sense" with more solemn horror than "and the last sea-shrick bellowed in " the air." The description ought to have closed with that line, and the next couplet should have immediately followed the paternal exclamation. Beyond the utmost power of the pencil do the six grand verses of this passage image death by ship- 
wreck; but the "white bones" and " ivory arms" of the concluding line, are every way exceptionable. They disturb the awful impression made on the mind by the last sea-shriek. Aiming to be pathetic they are in reality ludicrous, the ivory arms of bones! The bones of ivory arms we might understand, though it would be affected expression, but the converse terms seem nonsense. One of our existing poets, $\mathrm{Mr}$. Crowe, public orator at $\mathrm{Oxford}$, whose compositions, by their genuine excellence, atone for their too limited quantity, has told this sad story with solemn and simple beauty in his Lewesdon Hill, one of the noblest local poems in our language. In his narration we find nothing: which can strictly be termed picturesque, though the four introductory lines are highly so; but we find a great deal of Milton's manner in the progress of the tale, written in view of the rocks on which the Haleswell struck.

\section{LEWESDON HILL.*}

See how the sun, here clouded, afar off

Pours down the golden radiance of his light

Upon th' enridged sea, where the black ship

* This poem was printed at the Clarendon Press, Oxford, 1788, and sold by Prince and Cook of that city, and Cade!l Rivington and Faulder, London. 
Sails on the phosphor-seaming waves.....5o fair,

But falsely flattering, was yon surface calm,

Where forth for India sail'd, in evil hour,

That vessel, whose disastrous fate, when told,

Fill'd every breast with horror, and each eye

With piteous tears, so cruel was the loss!

Methinks I see her, by the wintry storm

Shatter'd and driven along past yonder isle!

She strove, her latest hope by strength or art,

'To gain the port within it; or' at worst,

To shun that harbourless and hollow coast,

From Portland eastward to the Promontory,

Where still St. Albans' high-built chappel stands。

But art nor strength avail her, on she drives,

In storm and darkness to that fatal coast!

And there, mid rocks and high o'erhanging cliffs',

Dash'd piteously, with all her precious freight

Was lost, by Neptune's wild and foamy jaws

Swallow'd up quick! The richest laden ship

Of spicy Ternate, or that, annual sent

'To the Philippines o'er the southern main

From Acapulco, carrying massy gold,

Were poor to this; freighted with hopeful youth

And beauty, and high courage undismay'd

By mortal terrors; and paternal love,

Strong and unconquerable, even in death.

Alas! they perish'd all,....all in ONE HOUR?

Resuming the principal subject of these strictures, we find the harmonic discoveries attributed to the aerial hand-maids. Their mistress supposes them to have breathed their grand and exquisite inspirations into the ear of Handel; to wake the 
tones on the shell of Echo; to melt in sweet chords upon the Eolian harp; and on the lips of Cecilia to breathe the song. Another lovely picture arises here, from an ancient gem, Cupid on a Lion's back, playing on a lute.

The Goddess proceeds to consider her Nymphs of Air as Ministers of Divine Vengeance on the Guilty, through the medium of tempests, and the pestilential winds of the East, as Samiel Harmattan, \&c. and the scripture story of the fate of Senacherib is told. The ravage of death, produced by those pestilential gales forms a sublime personification; thus,

Hark! o'er the camp the venomed tempest sings!

Man falls on man; on buckler buckler rings;

Groan answers groan; to anguish anguish yields, And death's dread accents shake the tented fields. High rears the Fiend his grinning jaws, and wide Spans the pale nations with colossal stride; Waves his broad falchion with uplifted hand, And his vast shadow darkens all the land!

Whether by coincidence or plagiarism on the part of Dr. Darwin, is uncertain, but in Mr. Sergeant's noble prophetic Ode on the Woes of the House of Stuart, commencing with fair unfortunate Mary's calamities, we find the last sublime image, thus, 
From Orkney's stormy steep

The spirit of the isles infuriate came;

Round him flash'd the arctic flame,

His dark cloud shadow'd the contentious dcep!

This Ode was published in 1788. The Economy of Vegetation in 1791.

That poem proceeds with another exhortation to the etherial Cohorts to protect the vernal children; impart the talisman which guides the veering winds, and, by its influence, enchain Boreas and Eurus, so often fatal to early luxuriance, vegetable and animal. Thus shall they, she beautifully says,

Rock th' uncurtain'd cradle of the year.

The destruction and reproduction of the atmosphere, is allegorised by a monster of magnitude more immense than that of Satan, when, on the page of Milton, he strides from hill to hill. This is a Camelion beneath the northern constellation. We find much grandeur of fancy in this aerial giant. His groan is the thunder, his sigh the tempest, as he steers his course to the south, and spreads his shadowy limbs over the line, with frost and famine in his track. The Sylphs are adjured to direct his course to benevolent purposes; to cool 
Arabian vales with his antarctic breathing; and, in the following harmonious line,

To scatter roses o'er Zelandic snows.

This allegory concludes unhappily, with a personal compliment to Mr. Kirwan, "who has pub"lished a valuable Treatise on the temperature of "Climates." Those compliments to ingenious professors would often find their more proper place in the notes, except where they form a simile; but as in this instance, a living man placed between the dragon wings of an imaginary and immeasurable monster, is a ridiculous idea. Often through the course of this work, does such intemixture of actual and ideal beings clisturb and interrupt, rather than agreeably diversify, the course of the allegory. The soon-ensuing mention of the celebrated Herschel, and his stellar discoveries, is made in the form of a simile, and is therefore unexceptionable; and it passes on to the following charming apostrophe to the Stars :

Roll on, ye Stars! exult in youthful prime, Mark, with bright curves, the printiess steps of Time!

Near, and more near, your beamy cars approach,

And lessening orbs on lessening orbs incroach.

Flowers of the sky! ye too to age must yich,

Frail as your silken sisters of the ficld; 
Star after star from heav'n's high arch shall rush,

Suns sink on suns, and systems systems crush;

Headlong, extinct, to one dark centre fall, And Death, and Night, and Chaos cover all;

Tillo'er the wreck, emerging from the storm;

Immortal nature lifts her changeful form;

Mounts from her funeral pyre on wings of flame,

And soars, and shines, another and the same.

Returning to the vegetable embryons, of which the Goddess, between her mention of Kirwan and Herschel had spoken, she thus beautifully says:

Lo! on cach seed, within its tender rind, Life's golden threads; in endless circles wind; Maze within maze the lucid webs are roll'd, And, as they burst, the living flames unfold.

The whole passage is equally fine, and closes thus:

Life buds, or breathes, from Indus to the Poles, And the vast surface kindles as it rolls.

We find the same image applied to Light in the first Canto, as it is here to Vitality. Speaking of Chaos-the Poet says:

Through all his realms the kindling Ether runs.

Yet far from censuring the very infrequent repetitions, which we may find through this great 
work, wonder and praise will rise in the mind of every true lover of the poetic art, contemplating that exhaustless variety of ideas, imagery and expression, which light up the subject with a thousand torches, kindled at the orb of Genius.

Skilful biendings of philosophic knowledge with poetic fancy, now occur in the birth and growth of plants and flowers. They are compared to the kindling and expansion of animal life in the $\mathrm{C}_{\mathrm{r}}$ ocodile, bursting from its egg on the shores of the Nile. It is a grand picture, though of somewhat forced introduction. The charge on its progress contains instruction to gardners, though it is addressed to the Sylphs, and adorned by the parable of Aaron's rod. The banishment of noxious insects by their cares, is enforced by the example of the Cyprepedia, a flower curiously resembling the large American Spider. Linnæus asserts, that it catches small birds as well as insects, and has the venomous bite of a serpent; and a French naturalist narrates, that it catches the humming-bird in its strong nets. The circumstance is thus elegantly pictured in the Botanic Queen's horicultural adjurations,

So where the humming-bird, in Chili's bowers, On murmuring pinions robs the pendant fowers; Seeks where fine pores their dulcet balms distill, And sucks the treasure with proboscis bill, Fell Cyprepedia, ixc. 
The diseases of plants are next pointed out, and they are illustrated by a curious fact in glassmaking. The pictures of various flowers next rise on the page, in botanic discrimination, and in all the hues of poetry. The exotic wealth of the Royal Garden at Kew is celebrated; and the conscious pride of its river, on the occasion is thus sweetly fancied:

Delighted Thames through tropic umbrage glides, The fiowers antarctic bending o'er his sides; Drinks the new tints, the scents unknown inhales, And calls the Sons of Science to the vales.

Poetic homage is then paid to our $\mathrm{King}$ and Queen, to their virtues, their taste for Botanic Science, and to the fair human Scions which themselves have raised.

The Goddess compliments her aerial Legions on attending the chariot of the morning round the earth, on leading the gay Hours along the horizon; on showering the light on every clun meridian, and on pursuing, from zone to zone, the perennial journey of the Spring. She commissions them, on this their radiant tour, to bring her rich balms from the hallowed glacles of Mecca, Arabian flowers, Italian fituits, and the tea-plants of China; also, 
Each spicy rind which sultry India boasts,

Scenting the night-air round her breezy coasts;

Roots, whose bold stems in bleak Siberia blow,

And gem with many a tint th' eternal snow;

Barks, whose broad umbrage high in ether waves

O'er Ande's steeps, and hides his golden caves.

Thus, with happy art, the Poet diversifies and animates floral enumeration with gleams of every-regioned landscape.

The Sylphs are then commanded to raise an alter to Hygeia; to call to its rites the clispersed Sisterhood, the Water Nymphs, from their floating clouds, their waves and fountains; to stamp with charmed foot, and convolie the Gnomes from their subterranean palaces; and to beckon from their spheres the vectal forms of fire; that thus, in full congregation, they may win the Goddess of Health with unwearied vows. The picturesque attitudes of supplication, which she dictates, are chinently beautiful; and, with a patriotic apostrophe to Hygein, the British Queen of Botany con-. cludes her cmbassy:

O wave, Hygeia, o'er Britamia's throne Thy serpent wand, and mark it for thy own!

Lead round her breezy coasts thy guardian trains,

Her nodding forests, and her waving plains !

Shed o'er her peopled realms thy beamy smile,

And with thy airy temple crown her isle! 
The Goddess of Botany now ascends with as much elegance as she had descended, and with more magnificence. If the reader is susceptible of poetic beauty; if he can feel that what never can be seen in reality, may yet be painted naturally; a strict survey of this poetical ascension will enable him to perceive, what indeed countless other instances in this Poem evince, that its author most eminently possessed that rare talent.

The Goddess ceas'd, and calling from afar The wandering Zephyrs, joins them to her car;

Mounts with light bound, and graceful as she bends,

Whirls the long lash, the flexile rein extends;

On whispering wheels the silver axle slides,

Climbs into air, and cleaves the crystal tides;

Burst from its pearly chains, her amber hair

Streams o'er her ivory shoulders, buoy'd in air';

Swells her white veil, with ruby clasp confin'd

Round her fair brow, and undulates behind;

The lessening coursers rise in spiral rings,

Pierce the slow-sailing clouds, and stretch their shadowy wings。

If we could see a light vehicle mount the horizon, its wheels would whisper, its axle slide; so would it climb into air, so divide the etherial currents, as a boat divides the waves of the river or 


$$
\text { DR. DARWIN. }
$$

or the sea; the coursers would rise in spiral rings and pervade the clouds; their wings would appear shadowy till they melted into air. Thus conchides the Economy_of Vegetation. 


\section{CHAP. VI.}

WE now come to yet more playful compo. sition in the second part of this Poem, as the floral system is a lighter and $\xi_{\mathrm{s}} \mathrm{s}$ important theme than the elementary properties, however generally gay the robes in which poetic imagination has dressed - them both; but let it never be forgotten that the sexual nature of plants has a demonstrated existence.

The Preface to this second part is a compendium of the Linnæn system. The Poem makes lively, yet very modest clisims for the succeeding metamorphoses, amid whose lighter graces we meet with passages of intrinsic grandeur and sublimity.

\section{LOVES OF THE PLANTS.}

In which the Poet ordains that the Muse of Botany shall succeed to its ascended Empress, as historian of the scene, and dictatress to its dramatis 
personæ. He introduces her by invoking, in his own person, the attentive silence of the winds, the waters, and the trees, and by requesting the insects to pause upon their wings. Eight different insects are mentioned, and each forms a striking picture of its whole species, by the Poet having seized and exhibited its most characteristic feature. He next apostrophises the Muse who "led the Swedish "Sage by her airy hand," intreating her to say how tiny Graces divell on every leaf, and how the pleasures laugh in the bell of a blossom.

The Ovidian metamorphosis of the flowers then commences. The floral ladies, and their harems, rise to the amused eye in all the glow of poetic colouring. Attentive to diversify them by the varieties of land cape, we generally find this Poet producing contrasted scenery by the introduction of flowers or plants which are indigenous to climates strikingly the reverse of each other. Much of that happy skill has been displayed in the Economy of Vegetation, and instances may be selected from this its brilliant precursor. After several plants and flowers have passed before us in the semblance of beautiful women, with their trains of adoring lovers, we find the following sketches of contrasted landscape, attached to the history of the social heath-plant, Anthoxa, or vernal grass, and 
the lonely Osmunda, which grows on moist racks and in their caverns :

Two gentle shepherds, and their sister wives,

With thee, Anthoxa, lead ambrosial lives;

Where the wide heath its purple bed extends,

And scatter'd furze its golden lustre blends,

Clos'd in a green recess, unenvied lot!

The blue smoke rises from their turf-built cot;

Bosom'd in fragrance blush their infant train,

Eye the warm sun, and drink the silver rain.

- Beauteous Osmunda seeks the silent dell,

The ivy canopy, the dripping cell.

In the description of the Chondrilla and her five amicable lovers, we find, in their accordant sympathy with each other, a supposed resemblance to the unison-strings of the Eolian harp ; and there is a sweet enumeration of the excellencies of its varied style of tones and expression.

To the picture of the Lychnis succeeds that of Gloriosa Superba, with her successive train of lovers, the second number rising to maturity when the first perish. This libertine lady of the groves introduces the story of the celebrated female Voluptuary, in the reign of Louis the fourteenth, Ninon de L'Enclos, whose beauty and graces are recorded to have been triumphant over the power of 'Time. The story of that passion, so terrible in its conse- 
quences, with which she unintentionally inspired her natural son by Lord Jersey of England, is finely told in this part; that son, totally unconscious of his birth and fatal nearness of blood to the charming Madam de L'Enclos! In the first edition of the Loves of the Plants this extraordinary woman received both personal and mental injustice from the prelude to that story. She is there represented by the Poet, as wrinkled, grey, and paralytic ; circumstances incompatible with the possibility of the attachment, and contrary to the representation of her biographers. Upon their testimony we learn that Ninon retained a large portion of her personal beauty and graces to an almost incredible. period; that it was considerable enough to procure her young lovers at the age of eighty, whose passion for her, however inconceivable, could not be interested, as she was not rich, and much too dclicate in her sentiments to purchase the attention of the other sex.

When her son, by Lord Jersey, was a young officer about Court, known to her but unknown to himself, Madame de L'Enclos was scarcely forty years old, a period at which a very captivating degree of beauty and grace is sometimes found in the female sex. Of their cxistence at a considerably later period, the English fashiona- 
ble circles, at this hour, exhibit some remarkablc instances.

In the first edition of this Poem what is here fatal smiles was harlot smiles, an epithet most injurious to Madame de L'Enclos. Her attentions to her son, however affectionate, must have been purely maternal, though so deplorable in their consequences. The declaration by which she repulses his impious suit, entirely acquits her of the least design to inspire him with passion. Dr. Darwin was influenced by the author of this Memoir to rescue the form of Ninon from the unreal decrepitude he had imputed to it, and her principles from such unnatural excess of depravity.

If we may credit her historians, Ninon was an exception to a maxim of the Duke de Rochefoucault, which has perhaps very few exceptions, viz. "Generally speaking, the least fault of an unchaste woman is her unchastity." Considering this remark as an axiom, the reason probably is, that chastity being the point of honour, as well as of virtue in women, its violation has a strong tendency to engraft deceit and malignity upon the secret consciousness of self-abasement; a consciousness more fatal to the existence of other good qualities than voluptuousncss itself; 
a consciousness too likely to produce hatred and envy towards people of spotless reputation, together with a desire to reduce others to their own unfortunate level. The great Moralist of the Old Testament, says, "There is no wicked" ness like the wickedness of a woman;" not because the weaker sex are naturally more depraved, but from the improbability that a fallen female should ever, even upon the sincerest repentance, regain the esteem and confidence of society, while it pardons a male libertine the instant he seems disposed to forsake his vice, and too often during its full carcer.

But the fault of Madame de L'Enclos was single, and surrounded by solid virtues. Truth sincerity, disinterested friendship, economy, generosity, and strict pecuniary justice, marked her commerce with the world, and secured to her the friendship and countenance of the most eminent people of that epoch, both as to talents and character.

The rigid and pious Madame de Maintenon never ceased to be her avowed and intimate friend, as appears from a most interesting dialogue which passed between them after Maintenon became the wife of Louis the Fourteenth. It will 
be found in the Memoirs of Madame de L'Enclos, which are elegantly translated from the French into our language, and were published by Dodsley in 1761. It is a very brilliant and entertaining work.

After the animation of the Silene, or Catch Fly, as an enchantress; after that of the Amarylis, illustrated by a beautiful picture of a church vane in the setting sun, the Ilex, or Holly, comes forward, with her giant lovers, grasping their thousand arrows. With this metamorphosis we find involved a lovely allusion to Needwood Forest, the late pride and glory of Staffordshire, now sacrificing, with all its prostrate honours, to a popular scheme of apprehended utility.

Mr. Wright's pictures are here introduced as a simile; but it must be confessed that not the most distant similitude can be traced between them and the Ilex, or Holly, which, as enchanters and giants, guard the Forest; but the poetic copy of these unallusive landscapes is trans. cendent.

The immense Kleinhovia, indigenous to the plains of Orixa, is presented as an amazonian nymph; and as the male parts of the tree are, in nature, supported by the female, she is pourtray. 
ed in Herculean beauty, bearing in her arms her puny lovers, trembling beneath the consciousness of her superior strength. A grand picture of the Grecian Thalestris, appropriate to the subject, thus illustrates the transformation:

So bright Thalestris shook her plumy crest, And bound in rigid mail her swelling breast, Pois'd her long lance amid the walks of war, And Beauty thunder'd from Bellona's car ; Greece, arm'd in vain; her captive heroes wove The chains of conquest with the wreaths of love.

The noble landscape of the late and wintered period of Autumn, quoted in an early part of these memoirs, introduces the personification of the tulip. The bulbous root of flowers is termed by Linnæus the hybernacle, or winter-lodge of the young plant. He says, " each bulb contains the leaves and " flowers in miniature, which are to be expanded " in the ensuing spring." The same embryon miniatures are found in the buds of the Hepatica, the Daphne-Mezereon, and at the base of Osmunda-Lunaria. The tulip in poetic animation, is a beautiful matron, fiying from the chill and stormy season to a lone cavem. She is then presented as sitting in that retreat, nursing her infant on her bosom till warmer days shall come. A pretty allu. 
sive description of the Dormouse, and its half year's slumber, adorns that passage.

Colchicum Autumnale, or Autumnal-meadowsweet, ascends amid the troubled air, with her attendant lovers. Thus eminent in beauty is the stella simile for that flower:

So shines, with silver guards, the Georgian star, And drives, on nights blue arch, his glittering car;

Hangs o'er the billowy clouds his lucid form,

Wades through the mist, and dances in the storm.

The Helianthus, or sun-flower, becomes a dervise, and leads his devout trains to worship the rising orb of day. Since the head of that majestic plant always, and by nutation, follows the course of the sun, it properly assumes the name and habits of a dervise or bramin. With this and the three succeeding metamorphoses, in themselves full of beauty and grace, the Drosera, or sun-dew, the Lonicera, or honey-suckle, and the Alpine Draba, sweet traits of contrasted landscape are blended; with Helianthus, the warm unshadowed lawns of morning; with Drosera the moist, the rush-enwoven and mossy scenes in which she wantons; with Draba, the icy caves and volcanos of Tenerif, amid which she builds her eyry,

Aspiring Draba builds her cagle nest ; 
and we are told that

Her tall shadow waves o'er the distant land.

When we learn, from the note on this passage, that Draba is one of the Alpine grasses, we wonder that so minute and dwarfish a plant should become so vast, commanding, and imperial in her transformation. The poet next exercises his Proteus art upon Viscum Misletoe, which never grows upon the ground, but grafts itself upon the branches of trees. This aerial nymph is shown as an angel of air, seeking amongst its clouds her soaring lovers.

When Zostera, Grasswrack, (which grows at the bottom of the ocean, and, rising to its top, covers many leagues with its leaves,) comes forth from beneath the wand of this potent magician, we meet one of the happiest sallies of his sportive pen. She is shown as Queen of the coral groves; her palace in the sea, supported on crystal columns, its turrets roofed with lucid shells, which dart their every-coloured rays afar into the deep; the shadows on its floor, philosophically described from the rising and breaking of the exterior billows; the mermaid-train enweaving orient pearls in her hair; her shooting up to the surface like a meteor; ascending the strand, and summoning, by a loudstruck shell, her sea-born lovers to attend her pro- 
gress; creative imagination, the high and peculiar province of the genuine poet, has few more beautiful creations than this marine picture and scene.

That curious plant of the polar regions, the Barometz, from its exterior resemblance to a sheep or lamb, is, by poetic magic, transformed into that animal, and to it the whale is compared, surely on no other possible relation, than as both the odd plant and the sea-monster, are natives of the arctic regions. The whale, however, makes a grand poetic picture:

Since then, the thing itself is rich and rare,

Exclaim not, "How the d......l came it there*!"

Mimosa, sensitive-plant, becomes a nymph of infinite delicacy. The objects aptly chosen to illustrate the nervous sensibility with which that plant recedes from the approaching hand, are thus described, and surely with no common happiness;

So sinks, or rises, with the changeful hour,

The liquid silver in its glassy tower;

So turns the needle to the pole it loves,

With fine vibrations quivering as it moves.

The Anemone and her modern-life objects of comparison, by no means form one of the gems

* Parody of Pope's lines on the Amber. 
of this poem however harmonious the lines. A lady's calash and a landau are out of their place in high heroic numbers. The Anemone and her trivialities, are sublimely contrasted by the rock-born Lichen, both in scenery and accomplishment. She has too much dignity from her surrounding landscape to have, or to want an illustrative simile. Her habitation is on the top of Snowden, nodding over the tumultuous river Conway; the hour midnight; the stars and cold moon gilding the rifted rocks; the whirlwind and dark thunder-storm rolling and bursting below the summit of the mountain. From its topmost stone the transformation of the Dipsaca conveys us to a valley glowing beneath the long prevalence of the dog-star, when the channel of every rill is dry, and the parched earth gapes. The personification of the plant has every graceful charm of a languid beauty.

The Rubia, madder, a plant used for the purpose of making a crimson dye, is compared to Medea bending over her caldron, in which youth was restored by immersion. It is an apt allusion to the faded beauty, who restores her lost bloom by rouge.

Vallisner, a curious aquatic plant of the Rhone, apostrophises, when in her human form, the stars and moon, shining at midnight on the 
shores of her watery home; and the sea-weed Ulva, with her young family, guarded on the deep by Halcyons, serves to introduce the famous $\mathrm{Ga}$ latea in her shelly chariot, drawn by dolphins over the ocean. She has more state and more superb attendants on her maritime progress, than Europa, in the second Canto of the Economy of Vegetation, or than the Nereid in the third; though in the picture of Galatea there is perhaps a less degree of originality.

But, upon the transformation of the Tremella, star-jelly, (a fungus often found in the state of transparent jelly, after it has been frozen in autumnal mornings,) the poet has lavished some of the finest effusions of his fancy. It is surely the transcendant passage of this second part of Dr. Darwin's poem. No eye has seen, or ever can see a beautiful nymph frozen into an ice-statue; but admit the possibility, and every circumstance of the gradual petrification is no less natural than it is lovely; nor can any degree of admiration be too high for the beauty and grace of the description. It is superior to the Ovidian Daphne.

This canto now prepares to close; the muse of Botany perceives a tempest approaching, and she is led by Wood-Nymphs into their most sequestered bowers. They suspend her lyre upon their laurel 
trees, and bind her brow with myrtles. If she had no other claim, the Tremella alone ought to give her wreath unperishable bloom. Symptoms of the impending shower are given with that accuracy with which, on every occasion, this genuine poet observed the objects of nature, thus:

Now the light swallow, with her airy brood,

Skims the green meadow and the dimpled flood.

Loud shrieks the lone thrush on her leafless thorn;

Th' alarmed beetle blows his bugle horn;

Each pendent spider weaves, with fingers fine,

Her ravell'd clue, and climbs along the line;

Gay Gnomes, in glittering circles, stand aloof Beneath a spreading mushroom's ample roof;

Swift bees, returning, seek their waxen cells,

And Sylphs hang quivering in the lily's bells;

Through the still air descend the genial showers,

And pearly rain-drops deck the laughing flowers.

An Interlude in prose succeeds to this Canto. It is a supposed dialague between the Poet and his Bookseller, in which the former gives us his ideas of the constitution of true Poetry. His first speech, "I am only a flower"painter, or occasionally attempt a landscape," is neither true, nor did Dr. Darwin desire that it should be considered as veritable.

In the course of this Interlude he will be found making much higher claims for himself, 
and too exclusively limiting poetry to the sphere of picturesque expression; yet his criticism on this line in Pope's Windsor Forest is perfectly just,

And Kennet swift, for silver Eels renown'd.

Since, whenever objects are introduced in verse, which, plainly mentioned, can excite no interest, it is questionless the Poet's duty to awaken interesting remembrance of them by little picturesque touches, such as we find in the Doctor's suggested change of that line, to

And Kennet swift, where silver graylings play.

His stricture upon Burke's style in prose, as much too ornamented, has surely little justice. Eloquence can only be produced by a strict union of strength and ornament. The Corinthian pillar is not less stable than the Doric; not less firm on account of its flowers. Dr. Darwin here seems to wish that prose should be precluded by its plainness from rising into eloquence. He wished to keep prose too plain, and his warmest admirers will surely acknowledge that he insists upon poetry being dressed with too elaborate magnificence. We find him in this Interlude, 
very ingenius on the subject of allegoric figures, also on that of dreams, and in his comparison of them to the reveries which the true Poet excites in his intelligent readers; but he is greatly indeed mistaken when he represents the art of exciting such rapt and abstracted sensations as solely consisting in picturesque writing. Instruction, pathos, all the grandeur and beauty of moral and religious sentiment, are here turned over to the prose writer, as if they were not equally capable of giving fascinating power to verse, as well as to oratory. The following passages are not picturesque; but no pictures ever presented by the muses, are more potent to impress, thrill, aud captivate that mind which is alive to the magic influence of their art:

Some say, that, ever, 'gainst the season comes At which our Saviour's birth is celebrated, The bird of dawning singeth all night long; And then, they say, no spirit walks abroad; The nights are wholesome; then no planets strike, No fairy takes, no witch hath power to charm, So hallow'd and so gracious is the time!

HANLET.

............. I fled, and cried out....Death;

Hell trembled at the hideous name, and sigh'd

Through allher caves, and back resouncied.....Death.

MIL TON. 


\section{if prayers}

Could alter high decrees, I to heaven's throne

Would speed before thee, and be louder heard

That on my head all might be visited,

Thy frailty and infirmer sex forgiven,

By me committed, and by me expos'd.

MILTON.

Remember March! the ides of March remember!

Did not great Julius bleed for justice' sake?

What villain touch'd his body, that did stab,

And not for justice? What! shall one of us,

That struck the foremost man in all the world

But for supporting robbers, shall we now

Contaminate our fingers with base bribes,

And sell the mighty space of our large honour's

For as much trash as may be grasped thus?

I had rather be a dog, and bay the moon,

Than such a Roman.

JuLiUS CefSAR。

Plac'd on this isthmus of a middle state

A Being darkly wise and rudely great;

With too much knowledge for the Sceptic side,

With too much weakness for the Stoic's pride,

Hehangs between, in doubt to act or rest,

In doubt to deem himself a god or beast;

In doubt his mind or body to prefer,

Born but to die, and reasoning but to err;

Sole judge of truth, in endless crror hurl'd,

The glory, jest, and riddle of the world.

POPE, on the Construction of Man.

Not e'en a spot unfought the hero gave,

No! till his foes had earn'd it, not a grave!

WESLEy, of King William the Third. 
Reflect, that lessen'd fame is ne'er regain'd, That virgin honour once is always stain'd! Timely advis'd the growing danger shun, Better not do the deed than weep it done! No penance can absolve a guilty, flame, Nor tears, that wash out sin, can wash out shame.

HENRY AND EMMA.

Methought I heard a voice cry, Slcep no more! Macbeth doth murder sleep! the innocent sleep! Sleep, that knits up the ravell'd sleeve of care, The death of each day's grief, sore labour's bath, Balm of hurt minds, chief nourisher in life's feast!

Still it cried, Sleep no more, to all the house, Glamis hath murder'd sleep, and therefore Cawdor Shall sleep no more, Macbeth shall sleep no more!

Who will call these passages prosaic? Who are they that will not confess them to be poetry, and such poetry as requires no aid from picture to establish its claims? Perhaps Dr. Darwin would not have deemed them sufficiently adorned, since all there is to the heart and nothing to the eye. To be consistent with the criticism of this his Interlude, he must have asserted their deficiency, and thus have proved that, while his imagination was so richly exuberant; while sublimity, as well as beauty, attended the commanding march of his Muse, there was a radical 
defect in his poetic system, which would forever have incapacitated him from being a first-rate Epic or Dramatic writer; but as nature hovered over the cradle of Shakspear, and gave him her golden keys, to unlock the gates of the Passions, so did Imagination over that of Dr. Darwin, and put into his grasp her magic wand, and spread over his form her every-coloured robe.

\section{SECOND CANTO.}

Again the goddess strikes the golden lyre, And tunes to wilder notes the warbling wire, With soft, suspended step Attention moves, And Silence hovers o'er the listening groves.

The second line of this passage is too alliterative, and therefore palls upon the ear. Alliteration is an edge tool in the poet's hand, improving or injuring his verse, as it is judiciously or injudiciously used. Homer, Virgil, Ovid, Spencer, Milton, and all the best poets, have employed it to admirable effect; and ito admirable effect has Dr. Darwin frequently employed it, though not in this instance. It often increases, and sometimes entirely constitutes, that power, which, by a metaphoric expression that literal terms would neither so concisely nor so well explain, is called pic- 
turesque sound. To increase the harmony of verse, alliteration must be with the vowels, the liquid letter $l$, or by the sonorous letters $m$ and $n$, and even with them its too frequent use in a poem, or too lavish repetition in a single line or couplet, will injure what it is designed to improve, as in the above second line of this second canto. Dryden, in his noble ode on St. Cecelia's day, has alliterated with the hissing $s$, in two lines, which he meant should be peculiarly musical; thus,

\section{Softly sweet in Lydian measures}

Soon he sooth'd the soul to pleasures.

A foreign ear would not endure the lines, which, however lively, are certainly, neither tender nor harmonious; yet the $s$, and all the harsher consonants, are capable of producing, by skilful application, that " echo of sound to sense," which is so eminently desirable in poetry. When Milton observes in the Paradise Lost,

\section{So talk'd the spirited sly snake,}

the line attains, solely by alliteration, the perfect hiss of the serpent; and Pope, in his Homer, by a masterly intermixture of the vowels and the sonorous consonants with his alliteration of the letter $s$, has nobly conveyed to our ear the peculiar noise of 
the ocean waves when they are loud on the beach; thus.

Silent he wander'd by the sounding main.

The murmur of a calm sea has been well expressed by the alliteration of the following line:

Slow on the damp and shelly shore she stray'd.

There is somewhere a line, in which a poetas. ter, mentioning the violet, says,

Where blue it blooms with balmy breath.

He thought he had hammered out an immensely fine verse, though in fact it is to the ear not a whit more" agreeable than

Three blue beans in one blue bladder.

The letters $b$ and $p$ make miserable alliteration. Milton has used the harsh letter $r$ to very fine effect in the following lines:

Vex'd Scylla, bathing in the sea that parts

Calabria from the hoarse Trinacrian shore.

Dr. Beattie, in his charming Minstrel has so used alliteration as to produce two of the most harmonious verses in our language. 
Young Edwin, lighted by the evening star,

Lingering and listening, wander'd down the vale.

'This digression into general criticism will not be thought irrevalent to the peculiar theme of these pages, when it is considered that, for the presumption of censuring, even in one instance, the eminently harmonious numbers of the Botanic Garden, it was requisite to justify such censure by examining the use or abuse of that habit of style, which strengthens or enfeebles, adorns or misbecomes the verse, as the good or bad taste of the writer shall direct its application. Churchill has ridiculed alliteration in a line of singular felicity, for an unworthy purpose, a satirical passage on the beautiful poetry of Mason; thus,

\section{.......... I, who never pray'd}

For apt alliteration's artful aid.

But the ridicule intended for the sweet Swan of the Humber, falls equally on the elder classics of Greece, Rome, and England.

The first transformation of this second canto is the Carline Thistle. We learn, from a note on the passage, that its seeds are furnished with a plume, by which they are borne through the air. Carlina, in human shape, is represented as fabri- 
cating Dædalion wings for herself and offspring, with most ingeniously described mechanism, and with happier success than those of the renowned mechanic in ancient fable.

And now succeeds, in happy similitude, a balloon-voyage, exact and accurate to the circumstances of aerial journeying in the first instance, and sublime in the imaginative part, the astronomic allusions: they are thus given :

Rise, great Mongolfier! urge thy venturous flight High o'er the moon's pale ice-reflected light; High o'er the pearly star, whose beamy horn Hangs in the east, gay harbinger of morn ;

Leave the red eye of Mars on rapid wing, Jove's silver guards, and Saturn's dusky ring; Leave the fair beams, that, issuing from afar, Play, with new lustre, round the Georgian star ; Shun, with strong oars, the sun's attractive throne, The sparkling zodiac, and the milky zone, Where headlong comets, with increasing force Through other systems bend their blazing course? For thee Cassiope her chair withdraws, For thee the Bear retracts his shaggy paws. High o'er the north thy golden orb shall roll, And blaze eternal round the wondering pole. So Argo, rising from the southern main, Lights with new stars, the blue etherial plain; With favouring beams the mariner protects, And the bold course, which first it steer'd, directs. 
So beautifully does this high priest of Fancy choose to constellate the first adventrous Aeronaut.

In the animation of Linum Flax we are presented with the exactest possible description of the machinery, and the art of weaving; and in that of Gossipiam, cotton plant, the late Sir Richard Arkwright's apparatus at Matlock, with the whole progress of its operations, is brought distinctly before the eye, recalling them to those by whom they have been examined, and instructing in their progress those who never beheld them.

So, in the personification of Cyperus Papyrus, under the name of Papyra, another art, that of printing, passes before us with equal precision. The leaves of this plant were first used in Egypt for paper, and gave the name, which it retains to this day; so, leaf, or folium, for the fold of a book. We have here, in sweet versification, the whole process of that inestimable invention, which paints thoughts, sounds, and numbers, in mystic and imperishable characters; imperishable, at least, during the reign of time. Yes, it was the encouragement given by that art to the sciences, which enabled this bard to throw over them all his splendid robe of descriptive poesy. The venerable and celebrated Mrs. Delany, sometime dleceased, and her mi- 
raculous Hortus Siccus, are here introduced as a simile to Papyra; but describing a totally different art from hers, even that of a mere artificial flowermaker, this simile, which bears so little resemblance to writing and printing, forms one of the most censurable passages in the whole poem. Mrs. Delany, in her representation of plants and flowers, native and exotic, and which fill ten immense folio volumes, used neither the wax, moss, nor wire, attributed to her in this entirely false description of her art. She employed no material but paper, which she herself, from her knowledge of chemistry, was enabled to dye of all hues, and, in every shade of each; no implement but her scissors, not once her pencil ; yet never did painting present a more exact representation of flowers of every colour, size, and cultivation, from the simple hedge and fieldflower, to the mosi complicated foliage that Horticulture has multiplied. This lady, once Mrs. Pendarvis, the friend and correspondent of Swift, and in her latter years honoured by the friendship, and frequent visits at Windsor, of the King, Queen, and Princesses, began this her astonishing, selfinvented work at the age of seventy.four. The Poet here misrepresents her, as being assisted by her virgin train. She had no assistant; no hands, but her own, formed one leaf or flower of the ten volumes. Her family were mortified by a descrip- 
tion which they justly thought degraded her peculiar art; and remonstrated with Dr. Darwin on the occasion, expressing a wish that future editions might contain its more just picture on his poetic page. He said the description in the note was accurate; but that truth in this, as in many other instances, being less favourable to poetry than fiction, he did not choose to alter the text.

The Lepsana, the Nymphea alba, and the Calendula, whose florrers, as do many ather flowers, open and shut at certain hours of the rising and declining day, are transformed into elegant female watch-makers. Limnus calls the forty-six flowers of this order, the Horologe, or Watch of Flora. This transformation involves an highly poetic description of the art that traces the march of time. The progressive mechanism which completes a watch, is traced with accuracy, and, in the mention of its ornamental trophies, we meet sublime imagery, such as time dashing superstition from its base, and the Hours leading their trains, around the wreck; but the Moments are impersonized with too much quaint prettiness. The whole of this imagery is an imitation, as indeed the author afterwards acknowiedges, of the following passage in Young's Night Thoughts. 
Each moment has its sickle, emulous

Of time's enormous scythe, whose ample sweep

Strikes emdires from the root; each moment plies

His little weapon in the narrow sphere

Of sweet domestic comfort, and cuts down

Our fairest blooms of sablunary bliss.

The hours leading their trains around the wrecks their parent had made, and planting amidst them the growth of science and taste, is an original and beautiful addition in Dr. Darwin's imitative passage. The moments are obnoxious to his own criticism in the first Interlude, they become unpleasing from being too distinctly described, with their kisses and their baby hands. Perhaps the personified moments are not less distinctly pourtrayed in the above passage from the Night Thoughts; but there, a pensive interesting moraliity casts over them a softening veil, while their gayer appearance and employment on the Darwinian page, brings them into glaring, and perhaps almost ludicrous view.

That unpleasing change, which takes place in the Helleborus after impregnation, produces, in its metamorphoses, a fair nymph suddenly smitten by a loathsome distemper, which utterly destroys her charms. An odd comparison ensues, the supposed actual transformation of Nebuchadnezzar 
into a beast; whereas the scripture only says, that he dwelt with the beasts of the field, and took their prone habits. His imputed change into their shape is ingeniously, but somewhat ludicrously painted; and we are apt to fancy the Euphrates slandered in these lines, which finely describe a river of sluggish and sullied current:

Lolls his red tongue, and from the reedy side Of slow Euphrates laps the muddy tide.

That harmoniously-named river of the East, has too long rolled through our imagination in beautiful and lucid currents, for us to like this reverse picture of its streams. One of our poets, probably Milton, has somewhere said,

and by the verdant side

Of palmy Euphrates.

At last, since the situation of Babylon was certainly flat and marshy, Dr. Darwin is probably correct in this instance, however obstinately our sensations may refuse to grant that one of the rivers which encircled Paradise can deserve to be so described; but there, as it was nearer its source in the mountain Niphates, it would certainly be more pure; besides, that it may be 
supposed to have become polluted by its progress through less hallowed earth. The last line of the Nebuchadnezzar-transformation is burlesque, by reason of the epithet pendant :

Nor Flattery's self can pierce his pendant ears.

And the alliterating $p$ makes the sound of the line displeasing as is the image it conveys.

The Menispernum, Indian-berry, which intoxicates fish, being of the class two females, twelve males, here assumes the form of two Sister Nymphs, scattering their inebriating berries on the waters. The Popish legend of St. Anthony preaching to the fish, and converting: them to Christianity, forms the whimsical and not very pleasing illustration. Its language violates the third commandment deplorably.

The Papaver, Poppy, becomes a drowsy Enchantress of malignant operation; but her somniferous palace is described in these lovely numbers :

Sopha'd on silk, amid her charm-built towers, Her meads of asphodel, and amaranth bowers, Where Sleep and Silence guard the soft abodes, In sullen apathy, Papaver nods. Faint o'er her couch, in scintillating streams, Pass the light forms of Fancy and of Dreams. 
Her enchantments are poetically given from old Tales of the Genii, and she is compared to Hermes driving the Ghosts to the shores of Erebus; and again his employment to the drawings of Miss Emma Crew, a compliment of very forced introduction.

The Cistus, a plant whose transient, but plenteous flowers expand in succession on the first warmth of May, becomes a Nymph, who calls her train to choir the birth of that month. She is obeyed, and a very exquisite song ensues, in which the altered measure releives the ear. Without any perceivable chain of thought, the sudden death of the fair Cista, serves to usher in a fine picture of an hoar-frost landscape, dissolving instantaneously beneath a change of keen to soft wind, accompanied by the emerging sun.

Cinchona, Peruvian bark tree, passes before us as a Peruvian Maid, on her way to the altar, which, in Quito, she had raised to the goddess Hygeia, and of which she is the administrant priestess. Her progress thither, and her ceremonies at the shrine, and her prayer to the Goddess, are beautiful; the personified Diseases sublime, particularly Ague. The accidentalmanner, in which, it is well known, the medicinal virtues of the bark were first discovered, is here 
conveyed to the reader with the happiest ingenuity, as a dictate of Hygeia to her Priestess, in answer to the prayer. Cinchona is commanded to yield her sacred forests to the axe, and to strew their bitter foliage on the rivers. She obeys; her lovers fell the trees, and impregnate the waters with the leaves, while pale infected squadrons kneel on the margin, and health and bloom return as they drink. All this forms a complete and charming little drama. It needed no illustration, but it has a very serious one, that of Moses in the Wilderness, striking the rock, "so that the " waters flowed out."

To the bark-metamorphosis succeeds that of the Digitalis, Fox-glove, of whose now experienced, though not infallible virtue, in cropsical cases, Dr. Darwin claims the first discovery. The bloated and cadaverous form of Dropsy appears, and his unquenchable thirst is compared to that of Tan. talus in these four admirable lines:

So bends tormented Tantalus to drink,

While from his lips the refluent waters shrink;

Again the rising stream his bosom laves,

And thirst consumes him 'mid circumfluent waves.

Hygeia assumes the form of Digitalis; waves over the diseased her serpent-wreathed wand, "and " charms the shape'ess monster into man." 
To her is compared the good Bishop of Marseilles, when the plague raged in that city; also the generous and active mayor of London, when London was under similar visitation. From him the Poet slides into a most animated contemplation of the great Howard's virtue, and asserts that the rays of philanthropy

Dart round the globe from Zembla to the Line;

O'er each dark prison plays the cheering light,

As northern lustres o'er the vault of night;

From realm to realm, by cross or crescent crown'd,

Where'er mankind and misery are found,

O'er burning sands, deep waves, or wilds of snow,

Thy Howard, journeying, seets the house of woe

Down many a winding step to dungeons dank,

Where anguish wails, and galling fetters clank;

To caves bestrew'd with many a mouldering bone;

And cells whose echoes only learn to groan;

Where no kind bar's a whispering friend disclose,

No sun-beam enters, and no zephyr blows,

He treads, inemulous of fame or wealth,

Profuse of toil, and prodigal of health;

With soft persuasive eloquence expands

Power's rigid heart, and opes his clenching hands ;

Leads stern-eyed Justice to the dark domains,

If not to sever, to relax the chains;

Or guides awaken'd Mercy through the gloom,

And shows the prison sister to the tomb;

Gives to her babes the self-clevoted wife,

To her fond husband, liberty and life! 
The spirits of the good, who bend from high, Wide o'er these earthly scenes, their partial eye; When first, array'd in Virtue's purest robe, They saw her Howard traversing the globe; Saw round his brow the sun-bright glory blaze In arrowy circles of unwearied rays, Mistook a mortal for an angel guest, And ask'd what seraph-foot the earth imprest. Onward he moves, Disease and Death retire, And murmuring Demons hate him, and admire.

If praise for a single verbal beauty may not degrade the exalted merit of the above quotation, the biographer would observe that its word inemulous has a sweet effect, and that, she believes, it is there in first coinage. Unambitious, the word in common use for that meaning, is comparatively hard and cumbrous in verse.

This citation cunstitues far the sublimest eulogy by which Poetry has immortaiized the matchless Howard, Mr. Hayley's noble Ode alone excepted. That was the earliest tribute to his high worth, and it is admirable in a degree which only Darwin hás equalled, and which perhaps no Poet can exce!.

The Gnomes now suspend the again silcnt lyre on the shrine of Hygeia; the Sylphs slacken the strings, and catch the rain-drops on their shadowy pinions, while a Naiad nrepares the tea-um. The 
last Canto closed with a shower. That it should rain also in the termination of this, is a sameness which surprises us from an imagination so various. Then surely there is too strong a contrast between the solemn and dignified praise of Howard, immediately preceding, and the light and frolic idea which places a Muse, the recent Historian of virtue so truly great, at the tea-table! It is out of keeping, as the painters say.

We meet ingenious and just criticism in the Interlude to this second Canto. Aware of the frequent want of evident resemblance between his subjects and their similies, Dr. Darwin shelters himself under the authority of Homer, which perhaps will not entirely secure his practice from censure; since, if Homer's similies do not often touch the object with which they are compared at all points, yet are they never so utterly without connexion with it, as several which may be found in this poem. That a poetic simile should not be precise in its resemblance is certain, at least that it is the more sublime, or more beautiful, for not quadrating cxactly; yet it ought to possess such a degree of affinity with the subject, that when the theme and its illustration are viewed together, we may feel, though we cannot verbally demonstrate the perfect justness of the similitude. 
Thus in general, are the similies of Homer constructed, and thus Milton's, several of which, in the Paradise Lost, are grander than most of those in the Iliad and Odyssey. A deceased modern Poet has given one of extreme beauty, which, from its aptness without precision, bears exactly that reIation to the object it illustrates which a poetic simile ought to bear. There is no obvious connexion between our idea of youthful beauty, paled and shadowed over by death, and a vernal dayspring, which rises cold and rainy:

Her face was like an April morn

Clad in a wintry cloud:

yet when Poetry connects them, -we are immediately sensible of their interesting affinity. Death itself cannot at first conceal, however it may shroud the traits of youth, and of what once was loveliness; neither can the dull sky and nipping wind prevent our perceiving the youth of the year, when April has put forth her fresh grass and verdant sprays.

In the course of Dr. Darwin's second Interlude, there is fine discrimination between the tragic and the disgustingly horrid; and his censure of the painters for their frequent choice of dis- 
agreeable subjects for their pencil, such as torture and carnage, is perfectly just.

From the pensive graces of this exordium result extended ground of censure for the undignified situation of the Muse at the close of the second Canto; since her modern Tea-table is here converted into a grassy throne, beclewed with tears, around which float the thin forms of Sorrows and Apprehensions, of Sighs whispering to the chords of her lyre, and Indignations, half unsheathing their swords. These same Indignations are new allegoric personages, and may be of dubious welcome. The Passions, with swords by their sides, form imagery which is liable to give a ludicrous impression; yet we should remember, that Milton puts a sword into the hand of the archangel, Michael, in the sixth book of the Paradise Lost, and Pope into that of a Ghost in his Elegy to the Memory of an unfortunate Lady; but Milton gives the weapon dignity by investing it with flames, on the authority of Scripture, and Pope softens off the literality by its imputed indistinctness, and by the epithet visionary. "Why dimly gleams the "visionary sword." 
Circea, Enchanter's Nightshade, is the first transformation in this Canto. We learn from the note to the passage, that it grows among the mouldering bones and decayed coffins of Sleaford Church, Lincolnshire, and that it was celebrated in the mysteries of witchcraft, and for the purpose of raising the devil.

As the Tremella is the most beautiful, so is Circea the sublimest transformation of the four Cantos. Her marriage with the two Fiends; its portentous signs which precede the satanic nuptials; the screaming bats, the owls, and the dog of midnight howling the epithalamium; the bursting ground; the ascending Demons; their progress with the grim Bride to the violated temple; those shapeless spectres, which, by glimpses of the moon through the coloured glass, are seen to quiver on the walls, as Circea and her horrid bridegrooms pass along the ailes, that dismally echo their steps; the unblessed wine with which they pollute the chalice; their hideous laugh which disturbs the silence of the choir; and the impious mummery of the nuptial rites; all these circumstances were conceived, and are expressed with prodigious strength of fancy. 
The Laura-cerasus, twenty males, one female, appears next, as the Pythian priestess* delivering: her oracles. This is her grand portrait:

Avaunt ye vulgar! from her sacred groves,

With maniac step, the Pythian Laura moves;

Full of the God her labouring bosom sighs,

Foam on her lips, and fury in her eyes,

Strong writhe her limbs; her wild dishevell'd hair

Starts from her laurel wreath, and swims in air,

While twenty priests the gorgeous shrine surround,

Cinctur'd with epods and with garlands crown'd,

Contending hosts, and trembling nations wait

The firm immutable behests of fate;

She speaks in thunder from her golden throne,

With words unwill'd, and wisdom not her own.

To the Pythian Laura is compared the dis. tress of a beautiful nymph in slumber, benesth the influence of the night-mare. It is a poetic picture after Fuseli. The squab and grinning Fiend, as he sits on the bosom of the sleeping Maid, and his moon-eyed mare, looking in through the bed curtains, are pictures of ludricous horror. They are drawn with rival strength by the Poet and Painter; and are contrasted by the lovely form of the agitat-

* The Pythian priestess is supposed to have been made drunk with the effusion of laurel leaves, when she delivered her oracles. The intuxication, or inspiration, is finely described by Virgilo. 
ed slumberer; but the succession of her convulsive appearances which the Poet brings to the eye, affords another instance of the superior powcr of the pen to that of the pencil, when eash are directed by the impulse of true genius.

The personification of the Indian fig-tree is made a vehicle of introduction for the scenery of Dovedale and Ilam, the cave of Thor, the Saxon God, and all the sanguinary sublimities of his druidical rites. The only connexion between the subject and its illustration is, that " each branch of the " large fig-tree of India, emits a slender, flexile, " depending appendage from its summit, like a cord, " and which roots into the earth, and rises again; " and the Hamps and Manifold, rivers of the Dove" dale vicinity, in their course over a romantic " moor, sink suddenly into the earth, and rise " again in Ilam gardens, after their subterranean "passage of three miles."

Impatiens, Touch-me-not, from the peculiar nature of the plant, and the elastic motion by which it throws its seeds to a great distance, has, in its transformation, sufficient afinity to the story of Medea, here introduced as its simile. Nowhere is that striking poetic legend so finely told. The passions of jealousy and despair, excited by the mercenary ingratitude of Jason, are here painted 
in their strongest colours, rising in power and force, till the dire filiacide closes the episode. Those electrical properties of the Dictamnus, Fraxinella, asserted by Dr. Darwin as having witnessed them in the still summer nights after long draught, induces him to transform her also into an enchantress, and the hour and season in which she celebrates her magical rites, is thus sweetly specified :

What time the Eve her gauze pellucid spreads O'er the dim flowers, and veils the misty meads, Slow o'er the twilight sands and leafy walks, In gloomy dignity, Dictamna stalks.

The deleterious tree, the Mancinella; the Urtica, English nettle, and the Lobelia longiflora, a deadly plant of the West Indies, form a continuation of Enchantresses, and their metamorphose is attended by still darker traits of demonism. As the first and last of these three vegetables have life-destroying properties, and the English nettle only inflicts a slight and transient pain, she ought not to have appeared in such company. Her comparative insignificance is that of a wasp between a cobracapella and a rattle-snake. The ruins of Palmira are described as a simile to the mischiefs of the four preced- 
ing witches, but why or wherefore defies all poetic guess; however, the fault of utter inconnection is atoned by the grandeur of this sombre picture.

To that succeeds the embrutality of the Upas Tree, now supposed to be of fabulous existence. It is preceded by a beautiful landscape of the Isle of Java, in the centre of which this dreadful tree was asserted to have stood. The seas of glass, the noble rocks, the ever-summered gales, and the sylvan graces which zone that large island, form an exquisite contrast in this passage, to the desolation round the Hydra Tree of Death, as its author sublimely calls it. The Upas Tree becomes a terrific monster under the wand of our potent magician. The enormous dragon is grand, with his unnumbered heads extending over ten square leagues, and with many infant serpents growing out of him, like those of Sin in the $\mathrm{Pa}$ radise Lost; a dragon, that

Lagks o'er the clouds, and hisses in the storm.

Into a monster the Upas must be made. This Poet's system of regetable animality would not permit it to remain in that so much more impres. sive though quicter horror, with which it is de- 
scribed in the Dutch surgeon's narrative. A lonely tree by the side of a rivulet, in a barren and stony valley, circled round by vast and sterile mountains; no tree but itself! no hedge! no blade of grass! no wing of bird! nothing that breathes to disturb the dreadful silence! dead bodies scattered about the waste in every various stage of putridity; and the tree itself exhaling a visible and poisonous vapor, instantly fatal to every living thing which breathes the air it taints within a diameter of fifteen miles! what furious dragon, even from the pen of Dr. Darwin, but loses its terrors before this still, this ghastly desolation!

The prose narration, taken from the London Magazine, is inserted in the close of the additional notes to the Loves of the Plants. It has such an air of simple veracity, that we do violence to our feelings when, on reflection, we refuse to give it credit. The gum of this tree is there asserted to be of high price, and used to envenom the Indian arrows; that it is procured by Criminals under sentence of death, who redeem their lives if they can bring from the Upas a box of its gum ; an experiment of immense hazard, since the possibility of returning depends upon the perpetually veering winds blowing a steady gale towards the tree as the delinquent. 
approaches it, in the progress of at least fifteen miles. The seldomness with which that happens, and the frequency of the attempt, strew the circumjacent plains with the dead. Faith in this wonderful tale has melted away in subsequent inquiry. Many have said that Dr. Darwin certainly believed the account. He certainly writes as if he believed it ; yet that was but to serve a poetic purpose ; credulity was not one of his propensities.

The Orchis Morio, the parent root of which shrivels up and dies as the young one increases, is transformed into a fond mother, nursing her infant at the expense of her own health and life. This animation is short, and, compared to many of the others, has little interest; but its two illustrations have every interest, and the second forms a sweet and mournful episode. The first is a lovely picture of a wounded deer, escaping from her ambushed archer, and flying with her fawn to the woodlands, over plains spotted with her blood; and, amid thick shades, hanging over her young, and weeping her life away. Then, in successive simile, comes the thrice interesting story. An Officer's Wife with her infants, watching, from a near hill, the battle of Minden, in which her husband was engaged, is mortally wounded by a random shot. We find this incident related with so much pathos as almost 
to dissipate the apprehension, that Dr. Darwin's rage for the picturesque would, in a subject of genuine interest for the human passions, have proved destructive to his powers of awakening them. The mournful truth of one line in this episode ought to sink deep in every human heart, viz.

The angel Pity shuns the walks of War.

Truly honourable is it to the Poets of this reign, that the best of them have never stimulated, but, on the contrary, have endeavoured to meliorate and abate that belligerent spirit, always injurious to the true interest of this country, and fruitful in the extreme of human misery: A spirit, by which Britain looks over the Atlantic, shorn of her continental beams ; a spirit, to whose unwarned and persisting violence in later years, the lives of the soldiery, and the comforts of millions of families, were lavished in defiance of the Gospel, which preaches peace on earth, and good-will towards men.

But to return to the episode; the lisping boy, on his father's approach.

Speak low, he cries, and gives his littie hand;

Eliza sleeps upon the dew-cold sand;

Poor weeping babe, with bloody fingers press'd, And tried, with pouting lips, the millkless breast. 
Alas! we both with cold and hunger quake,

Why do you weep? Mamma will soon awake!

She'll wake no more! the hapless mourner said!

Nothing can be more natural and more affecting than the ideas in this speech of the child, only that derv-cold and milkless are not infantine expressions.

The Cuscuta, Dodder, four males two females. It does not root itself in the earth, but ascends the vegetables in its neighbourhood, and ultimately destroys the plant on which it had grown to maturity. In this system of animality it is represented as two treacherous coquets, smiling to betray; and, from the circumstance of the plant twining round the shrub or tree, which it finally kills, the ungrateful beauties are compared to the serpents, which strangled Laocoon and his sons. That story here forms a faithful poetic picture of the celebrated statue.

In the transformation of the Vine into a Bacchanalian Female, the Doctor introduces, and enforces his just and favourite system, of considering the free use of vinous fluid, in all its stages, as the source of our most fatal chronic diseases. They are very poetically impersonised as they hover round the seductive nymph, Vitis, while Chemia mingles poison in her bowl.' This fell 
group is admirably illustrated by an image of Prometheus chained to a rock, with a vulture devouring his liver. The many disorders of the liver, so torturing and so fatal, which ebriety causes, are nobly allegorized in this fable of him, who is represented as being thus punished for having stolen fire from heaven. Dr. Darwin's note to this passage cleserves to be engraven on every man's memory, since it is the attestation of a great Physician, founded on an extensive practice of nearly half a century.

The Cyclamen, Shewbread or Sowbread, which, " when its seeds are ripe, gradually twists its stalk " spirally downward, till it touches the earth, and " there inserts its offspring," is changed into a tender matron, resigning her departed infants to the grave, and breathing a pious hope of their resurrection. The simile on this occasion is perhaps the sublimest passage in the whole work; its real, and, in former ages, often existing horrors, transcend in strength all Imagination has formed, or can form, with her train of spectres, witches, and demons:

So when the Plague, o'er London's gasping crowds, Shook her dark wing, and steer'd her murky clouds; When o'er the friendless bier no rites were read, No dirge slow chanted, and no pall outspread; 
While Death and Night pil'd up the naked throng? And Silence drove their ebon cars along, Six* lovely daughters, and their father, swept To the throng'd grave, Cleone saw, and wept. Her tender mind, with meek religion fraught, Drank, all-resign'd, Affiction's bitter draught ; Alive, and listening to the whisper'd groan Of other's woes, unmindful of her own.

One smiling boy, her last swect hope, she warms, Irush'd on her bosom, cradled in her arms. Daughter of woe! ere morn, in vain caress'd, Clung the cold babe upon thy milkless breast; With feeble cries thy last sad aid requir'd, Stretch'd its stiff limbs, and on thy lap expir'd! Long, with wide eye-lids, on her child she gaz'd, And long to Heav'n their tearless orbs she rais'd; Then, with quick foot and throbbing heart, she found Where Chartreuse open'd deep his holy ground; Bore her last treasure through the midnight glonm, And kneeling dropp'd it in the mighty tomb. "I follow next!" the frantic mourner said, And living plung'd amid the festering dead.

* During the last great plague in London, one pit, to receive the deat, was dug in the Charter-House, forty feet long, sixteen feet wide, and twenty feet deep, and in two weeks received 1114 bodics. During this dire calamity there were instances of mothers carrying their own children to those public graves; and of people deirrious, or in despair for the loss of friends, who threw themselves alive into these pits. See Journal of the Plague in 1665 , printed for E. Nutt, Royal Exchange. 
It appears to the author of this memoir, that, in the above solemn, great, and impressive episode, only two words, an epithet and its substantive, " ebon cars," could be changed to advantage. Ebony has a glossy and polished black, and is therefore of unsuitable resemblance to that vehicle of horror. Then amid the dreadful truths of the description, the dead cart should have been called. by its simple name; car, has a fine triumphant sound, which somewhat disturbs the awful horror of the impression. Surely the vehicle without nominal aiteration, and with a stronger epithet prefixed, that should not specify its complexion, would be better.

While Death and Night pil'd up the naked throng, And Silence drove their ghastly carts along.

From the banks of the Ontario we have the Cassia. It is one of those American fruits which are annually thrown on the coast of Norway, in wonderful emigration. Dr. Darwin accounts for it by a supposed existence of under currents in the depth of the ocean, or from vortexes of water passing from one country to another through caverns of the earth. 'The Cassia, ten males one female, is represented as a fair American matron, who, alarmed by the rising tempests, trusts her childen to 34. 
the floods. The Scripture tradition of Moses, committed to the Nile by his Hebrew mother, is here told with aptness to the subject, with picturesque beauty, and with pathetic sweetness. This child, rescued from the flood, and rising into an ambassador of Heaven, a mighty Prophet, that wrested the scourge from the oppressor's hand, and broke the iron bonds of his nation's slavery, nobly and religiously closes the passage ; and that close awfully contrasts the tenderness of the opening. From thence the Poet passes into another sublime philippic on the plague-spot in the mortal and religious health of Britain, her cruel Slave Trade, and makes this striking appeal to our senators :

E'en now, e'en now, on yonder western shores,

Weeps pale Despair, and writhing anguish roars:

E'en now in Afric's groves, with hideous yell,

Fierce Slavery stalks, and slips the dogs of hell;

From vale to vale the gathering cries rebound,

And sable nations tremble at the sound!

Ye bands of senators, whose suffrage sways

Britannia's realms; whom either Ind obeys;

Who right the injur'd, and reward the brave,

Stretch your strong arm, for ye have power to save:

Thron'd in the vaulted heart, his dread resort,

Inexorable Conscience holds his court ;

With still small voice the plots of guilt alarms,

Bears his mask'd brow, his lifted hands disarms; 
But wrapp'd in night, with terrors all his own,

He speaks in thunder when the deed is done.

Hear him, ye senates! hear this truth sublime,

He who allows oppression, shares the crime.

No radiant pearl, which crested Fortune wears,

No gem, that sparkling hangs from Beauty's ears;

Not the bright stars which night's blue arch adorn

Not rising suns that gild the vernal morn,

Shine with such lustre as the tear, that breaks

For other's woe, down Virtue's manly cheeks.

So admirably does this bard drop the curtain of moral truth and humanity over the tissues of his fancy, in this the grandest of his second-part cantos.

The muse of Botany now retires with much more serious grace from her choir than she had done in the preceding cantos, and it becomes her well, from the more sombre nature of its recent themes.

Alike ingenious and just are the critical observations with which this third interlude commences; they are on the relation between the arts of poetry and painting. In the progress of its strictures Dr. Darwin has not succeedcd so well. When he would establish affinity between the measures of metrical and musical composition, it was owing to his total want of knowledge in musical science that he is visionary, abstruse and incomprehensible. The 
instances he gives of fancied triple and common time in our verse, by no means support his theory, after all the pains which can be taken to comprehend it by those who understand both the arts. His suggested possibility of luminous harmony, accordant to that which is vocal, seems metaphysical in as wild extreme as the supposed analogy between the measures of poetry, and the time of music, had been unsuccessfully mathematical.

A pleasing instance of paternal eulogy occurs in this Interlude concerning the ingenious discovery on the harmony of colours, by Dr. Darwin of Shrewsbury. The demonstrated existerice of that harmony gives, as our poet justly observes, music and painting undoubted right to borrow metaphors from each other; "Musicians, to speak of the " brilliancy of sounds, and the light and shade of a " concerto; and painters, of the harmony of co"lours and the tone of a picture;" but, when he seeks to extend in our sensorium these real affini ies betreen the nature of colours and of musical sounds, into an equal relationship between the poetical and the nusical measures, he becomes incomprehensible to those who know the nature of cach too well to believe it possible that the mechanical divisions of musical time have their corresponding rules in the formation of English verse, 
whether blank or in rhyme. Perhaps the system may, as he asserts, extend to the possibility of setting pictures, as well as verbal expressions, to music, but not, surely, as Dr. Darwin supposes, with better effect than when music is adapted to the sentiments or the imagery of verse. The love of novelty only could have induced such a preference. It is conceivable that a picture, whether historic or scenic, might be exhibited while such harmonic strains are played by a band, as should well express the passions and feelings of the historic group before us, or the peculiar character of the landscape; but as the picture has only its moment, so must the corresponding melody and harmony of instruments have only one strain; no successive and contrasted movementś. Poetry and music are both progressive, painting is stationary, therefore the natural union is between the two first; and pictures can be worth nothing to the musician in his imitative art, in comparison with poetry, whose passions and scenes are changeful, often contrasted, and always proceeding.

Again, the poetic critic emerges into truth and day-light, when he compares the nature and privileges of the Greek and Latin languages with those of our orrn. Silent about the tones of each, where superiority is universally confessed to be with the 
two former, he proves that the constitution of the English language is, from its power of more variously compounding its terms, and from its greater facility in producing personifications, better calculated for poetry than the Greek and Latin. Accordingly our poetry has more imagery than that of either of those languages. From this comparison the author slides into the subject of plagiarism from the ancients, and from former bards of this nation. He distinguishes well what is, and what is not amenable to that censure, and acknowledges the few passages of borrowed ideas in the three preceding cantos. He says, "Where the sentiment " and expression are taken from other writers with" out due acknowledgment, an author is guilty of "plagiarism, but not on the testimony of single "words and casual phrases;" and adds, " they " are lawful game, wild by nature, the property of " all who can capture them. Perhaps a few com" mon flowers of speech may be gathered as we "pass over our neighbour's ground, but we must " not plunder his cultivated fruit." Dr. Darwin forgot that just restraint when he took, unacknowledged, forty-six entire lines, the published verses of his friend, for the exordium of the first part of his work. That extraordinary, and in a poet of so much genius, unprecedented instance of plagiarism 
excepted, not one great poet in England is more original than Darwin. His design, his ideas, his style, his manner, are wholly his own.

"Bright forms that glitter in the muse's ray,

"With orient hues, unborrow'd of the sun."

FOURTH CANTO

Opens with a sun-rise and a rain-bow, each of Homeric excellence. The muse of Botany gazes enchanted on the scene, and swells the song of $\mathrm{Pa}$ phos to softer chords. Her poet adds :

Long ailes of oak return'd the silver sound, And amorous Echoes talk'd along the ground.

This is almost verbatim from Pope's line,

And more than Echoes talk along the walls.

Plagiarism is atoned when it improves upon its original, and that is always to be expected from genius rich as Dr. Darwin's; but in the present instance we are disappointed. This generally so very accurate describer, here indolently sacrifices the verisimilitude of the circumstance, rather than change his rhymes. Echoes talk in the air, and 
along walls, but we never hear their voice at our feet. They are there in double inaccuracy, since if the oaken vistas returned the sound, that sound is echo; so we have first a literal echo, and immediately after, a plurality of personified echoes creeping on all four, and telling their imitative tales where no " Nymph of the airy cell," as Milton beautifully terms the echo, ever deigned even to whisper.

Suppose,

Long ailes of oak the silver sounds retain, And all their echoes breath'd the amorous strain.

Dr. Darwin proceeds to recal his readers to the local situation of his Muse:

Pleased Lichficld listen'd from her sacred bowcrs, Bow'd her tall groves, and shook her stately towers.

The first transformation of this Canto is the Cereus grandiflora, of Jamaica, twenty males one female. It flowers and becomes odoriferous during a few hours in the night, and then closes to open no more. The Cerea becomes a Miaid of Night, contemplating its "stellar suns ;" and she is compared to the Fairy Queen of Mr. Mundy's Poem, Needwood Forest, in a lovely strain, descriptive of the Elfin Sovercign. Of such a 
pleasing personage a second portrait is welcome. The reader may be gratified by comparing on this page the pictures of Titania from two Poets of whom Staffordshire may be proud.

NEEDWOOD FOREST.

Hark the soft lute! along the green

Moves, with majestic step, the Queen,

Attendant Fays around lier throng;

And trace the dance, or raise the song;

Or touch the shrill reed as they trip,

With finger light and ruby lip.

High on her brow sublime is borne

One scarlet woodbine's tremulous horn;

A gaudy bee-bird's ample plume

Sheds o'er her neck its wavy gloom;

With silvery gossamer entwin'd,

Stream the luxuriant locks behind.

Thin folds of tangled net-work break,

In airy waves adorn her neck;

Warp'd in his loom, the spider spread

The far diverging rays of thread.

One rose-leaf forms her crimson vest,

The loose edge crosses o'er her breast,

And one translucent fold, which fell

From a tall lily's ample bell,

Forms, with sweet grace, her snowy train,

Flows as she steps, and sweeps the plain.

Silence and Night enchanted gaze,

And Hesper hides his vanquish'd rays. 


\section{BOTANIC GARDEN.}

Thus, when old Needwood's hoary scenes the Night

Paints with blue shadow, and with milky light;

Where Mundy pour'd, the listening nymphs among,

Loud to the echoing vales his parting song,

With measur'd step the Fairy Sovereign treads,

Shakes her high plume, and glitters o'er the meads;

Round each green holly leads her sportive train,

And little footsteps mark the circled plain;

Each haunted rill with silver voices rings,

And Night's sweet bird in livelier accent sings.

The next floral animation, the Tropœclum Majus, Garden Nasturtion, eight males one female, is introduced by these lovely lines:

Ere the bright Star which leads the morning sky

Hang's o'er the milky East its diamond eye,

The chaste Tropce leaves her secret bed:

And saint-like glory trembles round her head;

- alluding to the "electric fiashes, which Miss E. " C. Linnæus first observed about this flower in " a summer morning; before sun-rise." A plenty and pomp of illustration is allotted to this flower; first the fire-fly of the tropics; next the ignisfatuus, which Dr. Darwin had deemed fabulous; and last the intrepid Youths of Judea, con- 
demned by Nebuchadnezzar to the burning fiery furnace.

With sublime simplicity has the Prophet Daniel told that story. Beneath every remembrance in favour of the inspired historian, we are here impressed and charmed anew by grandeur of imagery and picture, suited to the miraculous greatness of the scene. We again behold the blazing. deluge, the fiery cavern, white with seven-fold heat; the three Heroes in the midst;

And now a fourth, with Seraph-beauty bright, Descends; accosts them; and outshines the light.

Fierce flames innocuous, as they step, retire, And slow they move amid a world of fire!

How beautiful is the latter part of the second line!

The Avena, Oat, three males two females, becomes a pair of musical nymphs, alluding to the oaten pipes of early times, perhaps the first invented instrument of the harmonious science. The sister Avenas sing a lovely pastoral ballad, whose shorter measure again, as twice before, in the course of this poem, agreeably relieves the ear.

Cannabis, Chinese Hemp, is introduced by this fine appropriate landscape, where China, 
O'er desert sands, deep gulfs, and hills sublime

Extends her massy wall from clime to clime;

With bells and dragons crests her Pagod-bowers,

Her silken palaces, and porcelain towers;

With long canals a thousand nations laves,

Plants all her wilds, and peoples all her waves ;

Slow treads fair Cannabis the breezy strand,

The distaff streams dishevell'd in her hand.

The female form is always attractive from the poetic pencil of Darwin. Even the homely distaff becomes elegant, as in the hand of a fair Nymph, its flax is boyant on the gales of morning. Cannabis proceeds in her spinning, and the Graces hover around her wheel ; yet to her is "stern Clotho" compared, who weaves the web of Human Destiny, " the cradle and the coffin binding its ends;" but the Lady is here in her kindest mood, auspicious Fortune turning the giddly wheel;

But if sweet Love, with baby-fingers, twines, And wets, with dewy lips, the lengthening lines,

Skein after skein celestial tints unfold, And all the silken tissue shines with gold.

Galanthus Nivalis, Snow-drop, six males one female, is introduced as a delicate and sprightly lady, playing amidst a wintery scene of silent floods, white hills, and glittering meadows. She chides 
the tardy Spring, and commands the West Wind to stretch his folded pinions. She awakens the hoarse Cuckow in his gloomy cavern, calls the wondering Dormouse from his temporary grave; bids the mute Redbreast, enliven the budding groves, and the plighted Ringdove con. The Redbreast, however, is not mute amid the hybernal silence of nature, he warbles on the hoary spray.

Bellis Prolifera, Hen and Chicken Daisy, next becomes an affectionate matron, surrounded by her happy infants. Their childish sports, with the insects of the advanced Spring, and with the harebells and primroses, form a domestic scene of tender and lively interest. In the course of it a compound epithet for the Snail brings that reptile instantly to the eye :

Admire his eye-tipp'd horns and painted mail;

also, by the adverb, pausing, " the pausing but"terfly," is that gay insect recalled to us on its" airy evolutions. Venus and her Loves making arrows for Cupid in Vulcan's forge, is given as a simile to that scene; if simile it may be called which similitude has none. However, the mechanism of bow and arrow-making is presented with very amusing precision. 
Evidently to support a splendid prelusive description of Matlock, and the theory of the warmth of its fountain proceeding from internal volcano, is the aquatic plant, the Fucus, introduced, which, we are told, soon appears in all basins that contain water. The Fucus is represented as a beauteous youth, who bathes his fair forehead in the streaming fountain. The scriptural Angel who shook his plumes over the pool of Bethesda, illustrates the Fucus, presiding over the salubrious springs of Matlock. This simile has much propriety, since Dr. Priestley informs us that " great quantities of " pure dephlogisticated air are given up in water at " the points of the Fucus, particularly in the sun"shine, and that hence it contributes to preserve " the water in reservoirs from becoming putrid."

Trapa, four males one female, another acquatic plant, comes before us; thus,

Amphibious Nymph, from Nile's polific bed Emerging Trapa, lifts her pearly head.

Fair glows her virgin cheek and modest breast,

A panoply of scales deforms the rest;

Her quivering fins and panting gills she hides,

But spreads her silver arms upon the tides;

Slow as she sails, her ivory neck she laves, And shakes her golden tresses o'er the waves.

Charm'd round the Nymph, in circling gambols glide

Four Nereid forms, or shoot along the tide; 
Now, all as one, they rise with frolic spring, And beat the wondering air on humid wing;

Now all descending plunge beneath the main, And lash its foam with undulating train;

Above, below, they wheel, retreat, advance,

In air and ocean weave the mazy dance;

Bow their quick heads, and point their diamond eyes,

And twinkle to the sun with crer changing dies.

By this picture we are reminded of the figure of $\operatorname{Sin}$ at the gates of hell.

The one seem'd woman to the waist, and fair,

But ended foul in many a scaly folk,

Voluminous and vast!

Milton's Paradise Lost.

The ensuing transformation conveys us from the flat shores of the Nile to the base of the Andes. The plant is the Ocymum Salinum, Saline Basil, two males two females. She is complimented with chastity as having but one lover. Her situation presents a fine landscape, and her form is arrayed in every feminine and modest attraction. The spray: of ocean bathes her delicate limbs, uncurls her amber-hued tresses, and encrusts her person with saline films, through which, as from amidst a shrine of chrystal, her beauty beams. To this saline plant belongs a note extremely worth the attention of the reader, since it contains an opinion of universal 
medicalimportance, from one of the most discerning physicians which perhaps the world has produced. It relates, by him, to the supposed pernicious effect of too frequent indulgence in that most agreeable of all the artificial tastes, the love of salt with our food. The transformation of the Ocymum Salinum brought to the Poet's memory the unfortunate wife of Lot, whose story is here told with great and pathetic beauty. Herself and husband are compared to Orpheus and Eurydice, to $\mathbb{E}$ Eneas and Creusa. The story concludes with a fine versification of the scriptural picture of the ruins of Sodom and Gomorrah. Perhaps it will be found somewhat inferior to Mason's paraphrase of the desolation of Babylon. The reader will compare the passages, and judge for himseif.

BOTANIC GARDEN.

Oft the lone Pilgrim, that his road forsakes, Marks the wide ruins and the sulphur'd lakes;

On mouldering piles, amid asphaltic mud, Hears the hoarse Bittern where Gomorrah stood: Recalls th' unhappy pair, with lifted eye, Leans on the crystal tomb, and breathes the silent sigh. 


\section{MASON'S ODE ON THE FATE OF TYRANNY.}

Where yon proud City stood

Now spreads the stagnant mud;

And there the Bittern in the sedge shall lurk,

Moaning with sullen strain,

While sweeping o'er the plain,

Destruction ends her work.

Arum, of the class Gynandria, or masculine ladies, becomes an Amazon, in the modern military garb, and its appendages. Dejanira exchanging her distaff for the lion-spoils of her mighty lover, illustrates the Haram in a beautiful poetic picture.

The mule-flower, produced from the union of the Dianthus Superbus, Proud Pink, and Caryo. phillus, Clove, produces, in the transformation of its parent flowers, a whimsical but highly ingenious comparison to the Persian fable of the amours of the Nightingale and the Rose. With romantic, but exquisite fancy is this amour, and its beautifully-monstered offspring, made out. That curious plant, the Chundali Borrum, whose history and strange habits are described in a note to the passage, is preceded by an African landscape of sublime features, beneath the rage of the Summer Solstice, and the poisonous breath of the Harmattan, the 
only gale that flits over the tawny hills. Gasping panthers are rolling in the dust, and dying serpents are writhing in foamy folds; the woods on Atlas, blasted by the heats, and the waters of the Gambia shrinking in their channels; Ocean rolling to land his sick shoals, and Contagion stalking along the shore. Amid the sultry waste rises the graceful nymph, Chunda, with her brow unturbaned, and with loosened zone. Her ten lovers are employed in mitigating for their fair mistress the ardors of the climate, with the umbrella and the fan.

Of equal excellence, a Greenland picture contrasts, in the utmost possible extreme, the preceding landscape. A dayless horizon, streaming with the milky light of the Aurora Borealis, and all the white mountains gleaming to the moon; Bears stalking slowly over the printed snows; and vast ribs of ice, bursting with the noise of loudest thunder. Then is shown the vernal dissolution of this scene, beneath the rising of the pale, sixmonths day; and the Muschus, Coral-Moss, in the form of an Arctic-regioned lover, awakens his Fair One, and describes the symptoms of returning Spring.

The lake and sea-plant, $\not E g g a$, Conscrva Augagropila, is next introduced by this beantiful Iine, 
Night's tinsel beams on smooth Loch-Lomond dance.

Where the charms of poetic sound are felt, that is one of the lines which, after perusal, takes possession of the memory, and lingers on the ear. We are told, in a note, that this vegctable is found loose in many lakes; that it is of a globular form, from the size of a walnut to that of a melon; does not adhere to any thing, but rolls from one part of the lake to the other. Here it becomes a fair maid, sitting on the banks of Loch-Lomond, expecting: her lover to swim to her from the centre of the water, and exploring, with anxious eyes, every passing wave. Since a number of aquatic plants had been previously humanized, it is probable this is indebted for such distinction to the inclination of the Poet to retell the celebrated story of Hero and Leander, after Ovid. As a simile it is perfectly comparative to the described situation and solicitude of $\mathbb{E}$ ga. Dr. Darwin was conscious of his rarely-equalled talent in descriptive story; of his power to bring objects full and distinct on the reader's eye, by attitude's, looks, and employments, peculiar to their situation. Ovid says, Hero hung her lamp in a tower which overlooked the Hellespont, that her lover, as he swam across the food, might see to steer his course by its light. The art of glass-making, unknown in those times, the 
danger of the lamp being blown out must have been imminent. It is therefore natural that Hero should assiduously strive to guard it from the wind. Of that picturesque circumstance Ovid did not avail himself. Our modern Bard has been happier.

So, on her sea-girt tower, fair Hero stood At parting day, and mark'd the dashing flood, While high in air, the glimmering rocks above, Shone the bright lamp, the pilot-star of love. With robe out-spread, the waving fla me behind, She kneels, and guards it from the rising wind ; Breathes to her Goddess* all her vows, and guides

Her bold Leander o'er the dusky tides;

Wrings his wet hair, his briny bosom warms,

And clasps her daring lover in her arms.

The charm of appropriation, as evinced in the third couplet of the above passage, exists only with the genuine Poet. Mere tuneful versifiers know nothing of it, they rest in general description, and general description has been long since exhausted. Genius knows this; he seizes the peculiar circumstance of the situation; pours all his strength and light upon that, and leaves to the reader to conceive the rilole by that distinct and luminous part; but for which, the scene would pass unimpressive over

* Hero was a Priestess of Venus. 
the mind of the examiner, and probably in no hour of recollection return to it again.

The Truffe, a well known fungus, which never appears above ground, now meets our attention as a fine lady, married to a Gnome, stretched on beds of silvery asbestos, beneath a grand subterranean palace; soothed by the music of the Eolian strings, which make love to the tender Echoes in the circumjacent caves; while Cupids hover round and shake celestial day from their bright lamps. It must be confessed that the Empress of this proud palace has not the claim of birthright to her splendor.

This personification is succeeded by that of Caprifica, Wild Fig, as a nymph who slumbers away her life on a downy couch. She is betrothed to a Sylph. Her awakening is compared to that of the insect in a nut, and to a young linnet on the instant of its first flight from the nest. Caprifica strikes a talisman, and her airy husband flies to her on the wings of a gnat. This flight is painted with lavish play of fancy; its swiftness is compared to that of the electric aura; its impatient constancy to that of the polar needle. The Byssus of the northern shores, which floats on their seas by day, and is found in their caverns, we see ushered to our notice by a sublime poetic picture of Fingall's 
Cave, of which Pennant's Tour to the Hebrides contains an engraving. The male and female of this vegetable become a Youth and Maid of those regions, pursuing their amorous voyage by night, in a boat with green sails, and lighted to their cave by the star of Venus.

Conferva Polymorpha, found on the English shores, from the changeful appearance of the substance, is termed a Proteus Lover, and is represented after that fable. Beneath this fancy we see him a Dolphin, a spotted Pard, a Swan; and traits of the manners of each of those animals give poetic value to the transformations.

Adonis, many males many females in the same flower. Here is the final metamorphosis of this great work of Imagination. The multifarious florets in each individual flower of that species, are made to assume the human figure, and to become a band of libertine lovers, who plight their promiscuous hymeneals. To them is compared that licentious institution, the Areoi of Otaheite, as recorded in Cook's Voyages.

And now the Muse of Botany dismisses her ministers, and closes her inchantments, thus:

Here ceas'd the Goddess. O'er the silent strings Applauding Zephyrs swept their fluttering wings; 
Enraptur'd Sylphs arose in murmuring crowds, To air-rvore canopies and pillowy clouds;

Each Gnome, reluctant sought his earthly cell, And each bright floret cloth'd her velvet bell.

Then, on soft tiptoe, Night, approaching near,

Hung o'er the tuneless lyre his sable ear;

Gemm'd with bright stars the still, etherial plain, And bade his nightingales repeat the strain.

These last verses drop the curtain, with serene dignity, over a brilliant little world of Genius and its creations. The passage may not possess the spirit and sublimity which attach to a number of others in this division. Probably the Poet remembered the plainness with which Homer, Virgil, and Milton, closed their Epics, and chose to diffuse over his farwel lines an emulous sobriety. Perhaps the whole Canto, with all its mass of picturesque elegance, has more sameness, less grandeur, less sublimity, than any of its predecessors in either part of this magnificent Poem. It seems to bear that species and degree of inferiority to the three former Cantos, as the Loves of the Plants, considered as an whole, bears to the sublimer first part, the Economy of Vegetation; where we find impersonised each various elementary property of Creation, as a race of ministrant Beings, endowed with 
scientific intelligence and benevolent powers. They rise before us, the Handmaids of Nature, ordained to watch over all her operations and productions, on earth and beneath it; in air and in ocean; as Nature herself appears in the semblance of the Goddess of Botany.

Perhaps it would have been better if her proper and general name, Nature, had been assigned to her in the Economy of Vegetation, and the botanic title been reserved exclusively for the Muse in the Second Part, who records the transformations and the loves of the Plants and Flowers. In that case, to her also would have been resigned the floral car and its gay descent, and a vehicle of graver mignificence supplied its place to the "Mighty mother," immortal Nature. Nymph, or Goddess of Botany, implies empire only over the vegetable part of creation; while, in the Economy of Vegetation, she presides over the astronomic, electric, aerial, and mineralogic properties. Into so wide a field has the union of Philosophy with Poetry conducted this daring Bard. The light of his imagination will shine with increasing lustre in the eyes of future generations, so long as discerning Taste shall be the Testal to watch and support its fires. 
Nor let it once be thought that any error in Dr. Darwin's poetic system; any occasional deviation from perfection in the plan, arrangement, or execution of this his complicated work, ought to prevent its being considered as one of the richest effusions of the poetic mind, that has shed lustre over Europe in the eighteenth cen. tury.

Human ability never did, and probably never will, produce an absolutely perfect composition. The author of this memoir has, from infancy, sedulously studied and compared the writing of the distinguished Bards of her nation, together with the best translations of those of Greece, Rome, and modern Italy. She has presumed to descant upon what appeared to her the graces and defects of the Botanic Garden; induced by a conviction that the unbiassed mixture of candid objection with due praise, better serves the interest of every science than blind unqualified encomium upon its profes. sors. Hence, rising genius may guard against the betraying influence of enthusiastic homage; which charmed by general excellence, melts down particular defect in its shining mass. So doing, the inexperienced and ardent fancy is full as liable to adopt the faults as to attain the merits of the author it emulates. 
By unprejudiced investigation, that sickly, partial, and fastidious taste which confines its attention and its praise to a few chosen and darling writers, may be induced to reflect, that if, after a just balance of beauty and defect, the first outweighs the latter in immense degree, then attention, love, and applause is due to that work as an whole, in which such preponderance is found.

Posterity, if not always, yet generally acts upon that fair principle in the measure of fame it allots, when the mists of projudice, from causes foreign to the intrinsic claims of an author, shall disperse. Those compositions which, with a considerable degree of genius, are yet level to the comprehension of ordinary minds, immediately attain their full measure of celebration; but it is seldom that poetry of the higher orders is exempt from those mists; it must struggle through them into full and universal day.

The slowly-accumulating suffrages of those discerning and generous readers who delight in fertilc and daring Genius, will accumulate for the Botanic Garden, as they have for many other pocms, whose early appreciation was dubious; whose celebration, during the life of their authors, was far from being uncontroverted. Whon 
that time shall come, the querulous and disdainful tones of peevish prejudice will not venture to assail the ear of an admiring Nation, proud of its distinguished Sons. Then, however imperfection may still be perceived in this as in all other works of bold imagination, it will be observed without acrimony, and with grateful delight in its plenteous atonement.

No eminent Poet has so many passages which are every way exceptionable, as the most eminent Poet that this, or perhaps any other nation has produced from the morning of Time, our great, our glorious Shakspeare. 


\section{CHAP. VII.}

BEFORE Dr. Darwin stood forth a candidate for the Delphic laurels, he was extremely alive to the beauties of poetic literature, as it rose and expanded around him. No person could be more ready to discern and to praise its graces; but, from the commencement of the Botanic Garden, the jealous spirit of authorism darkened his candor. When, with avowed delight in the poetic powers of Cowper's Task, the writer of these strictures, in conversation with Dr. Darwin and Sir Brooke Bothby, asked their opinion of that poem, each declared they could not read it through; each taxed it with egotism, with prosaicism, with a rough and slovenly style, and with utter want of regular design. Perhaps those censures, unbalanced by just praise, should not, however, be imputed solely to unworthy jealousy in either of those gentlemen; certainly not to Sir Brooke, at any rate, who, with all his native brilliance of fancy, was never tena. 
cious of the Muses' fivours. Both had always preferred rhyme to blank verse, asscrtirg that it better suited the nature of our language. Dr. Darwin had ever maintained a preference of Akenside's blank verse to Milton's; declared that it was of higher polish, of more classic purity, and more dignified construction. This perference may fairly allow us to place his blindness to the charms of the Task to the score of taste somewhat enervated. by too much refinement, rather than to soreness under rival reputation. A still more scrupulous attachment to classic elegance attaches to the opinions of Sir Brooke, respecting Poetry. It was thence, doubtless, that he became disgusted by the planless wanderings of Corper's Muse, in her principal work, and by the occasional roughness and prosaicism of its style. Another prejudice in the minds of each ras likely to have operated in producing this injustice to Cowper. Previous to the Task he had published poems in rhyme, into which they had probably looked. In those poems, whatever strength of thought may be found, the poetic essentials certainly are not, inharmonious as is their versification; barren as they are of landscape and picture, metaphor and imagery.

The author of the Task was more just to Darwin than he liad been to that spirited, that 
interesting; that often sublime, though not faultless composition. About the year 1792, Mr. Cowper sent Dr. Darwin a lively and pleasing encomium in verse upon the Botanic Garden. This agreeable eulogy justiy says, no Poet who can refuse to bestow a wreath on Darwin deserves to obtain one for himself. It was accompanied by another poetic tribute from Mr. Haley, of yet warmer praise and more brilliant grace.

Mr. Polwhele also addressed a fine sonnet to Dr. Darwin on his Botanic Garden, who, by inserting it in his work, proved that he thought highly of its merit, and that he considered such praise as genuine fame. The neglect of Mr. Polwhele's poetic writings is a disgrace to the present period of English literature.

Our botanic Poet had in general no taste for Sonncts, and particularly disliked Milton's. The characteristic beauties of the legitimate sonnet, its nervous condensation of idea, the graceful undulation of its varied pause, which blends with the sweetness of rhyme the dignity of blank verse, were all lost on Dr. Darwin, at least from the time in which he entertained the design of becoming a professed poet. Absorbed in the resolve of bringing the couplet-measure to a degree of sonorous perfection, which should transcend the numbers of 
Dryden and Pope, he sought to confine poetic excellence exclusively to that style.

" Desiring much the lctter'd world might own

"6 The countless forms of beauty only one."

From the time at which Dr. Darwin left Litchfield to reside at Derby, on the irresistible injunction of Love, the author of these memoirs will not attempt to trace more than the outline of his destiny, not possessing the means of giving its interior parts with sufficient precision.

The pen which on these leaves has pursued him through his ascending day to its meridian, may yet remark that Dr. Darwin's reputation as a poet first emanated from Derby, though his Delphic inspirations commenced at Lichfield; that as a physician his renown still increased as time rolled on, and his mortal life declined from its noon. Patients resorted to him, more and more from every part of the kingdom, and often from the continent. All ranks, all orders of society, all religions leaned upon his power to ameliorate disease, and to prolong existcnce. The rigid and stemly pious, who had attempted to renounce his aid from a supposition that no blessing would attend the prescriptions of a sceptic, sacrificed, after a time, their superstitious scruples to their involuntury consciousness of his mighty still. 
Wealth must have flowed in rapidly beneath employment of unprecedented extent, at least in any country practitioner; and from the large sums for which he sold the copy-right of his writings, poetic and philosophic. The sweet temper and benevolence of that long adored wife, for whose sake he had changed the sphere of action; the numerous young family which rose and bloomed around him, rendered the Lares of his hearth not less auspicious to Darwin than he had found the gifts of fortune and the voice of renown. His son Erasmus, by the former wife, had settled at Derby nearly as soon as himself went thither, and in the profession of the law obtained considerable practice with a fair reputation. The talents and virtues of his youngest son, by the first marriage, were making every promise of that prosperity which has since been amply fullilied.

The Zoonomia, of so much elder birth than the Botanic Garden, suffered her poetic younger sister to precede her on their entrance into the work of letters, and did not herself appear till the year 1794. Of the Zoonomia sufficient has been said in the former part of this biography, considering the writer's linited powers to speak of its excellences and defects. 
About thirteen or fourteen years after Dr. Darwin's second marriage, the Miss Parkers his relations, opened a female boarding-school at Ash. bourn in Derbyshire. To the education of these ingenious and good young women he had paid some general attention, and had sedulously and warmly, by recommendation and by other means, exerted himself to serve them. To promote the success of their undertaking he published, on its commencement, a small tract on Female Education. The precise time of its appearance is not recollected. The composition was by no means worthy of Dr. Darwin's exalted abilities. Its subject cannot be supposed to have employed much of his consideration.

The system of his whole life on that theme had been at war with all sorts of restraint on the time, the amusements, and the diet of children. Irony was the only corrective weapon he had ever used to his own. 'The docility of them all, and the talents and good qualities of his three eldest sons, one, alas! cut off in the dawn of manhood and of fame, and the happy prospects of the other two, had confirmed his disdain of incessant attention to young people. He always said, "If you would " not have your children arrogant, conceited, and "hypocritical, do not let them perceive that you 
"s are continually watching and attending to them; " nor can you keep that perpetual watch without " their peceiving it. Inspire them with a disdain " of meanness, falschood, and promise-breaking; " but do not try to effect this purpose by precept " and declamation, but, as occasion arises, by ex. "pressed contempt of such as commit those faults, " whether it be themselves or others. Teach them "benevolence and industry by your own example, " for children are emulous to acquire the habits of " advanced life, and attach to them an idea of dig" nity and importance."

Perhaps if Dr. Darwin had to this incomplicate and so easily practicable system, added the inspiration of religion by the same means, viz. expressed contempt for impiety, and daily example of grateful devotion, it would better answer the end of making wise and good men and women, than all the laboured treatises on education which have, of late years, been poured from the press; treatises so universally read, so seldom, if ever, even in the slightest degrce, reduced to practice! In truth they must be found impracticable, inconsistent as they are with the established habits of society. Obedience to their directions must devote every present generation, at least the maternal part of every present generation, to preparing the future. Every mother 
must be wholly absorbed in word-watching, and look-watching, and all this by book.

Yet was Dr. Darwin aware that these voluminous receipts to make human angels, or to make practical philosophers of every boy and girl in the higher and middle classes of life, were too popular for him, without sacrificing the design of his tract, to bring against them his own conciser plan; which, if rational, does away the utility of them all. His little work could not serve Miss Parkers if it com. bated the educating metaphysicians and their unt obeying admirers. Avoiding such combat; his treatise would certainly call the attention of the neighbourhood to the seminary for which it was written. Some good rules for promoting the health. of growing children will be found on its pages, and they promised unfeed attention from its author to the diseased in that school. On the whole, howe: ever, it is a meagre work, of little general interest those rules excepted, and with an odd recommendation of certain novels, of no eminence, to the perusal of young people. That was one of those follies of the wise, which daily present themselves to our surprised attention.

In the year 1791 a splendid archery-mecting was held at Drakelow in Staffordshire, the seat of Sir Nigel Gresley. Miss Susan Sneyd*, of Bel-

* Now Mrs. Broughton. 
mont, was distinguished by her skill and success in the contest of that day. Honoured by Dr. Darwin's celebration, her name and her unerring arrow, are on permanent record. The verses he wrote on that occasion appeared in the Derby paper anonymously. There were people who pretended to be judges of verse, and yet were in doubt concerning their author. Before Dr. Darwin acknowledged them, they were attributed to various versifiers; and when the writer of this tract, who sarv the Darwinian stamp on the lines at one glance, declared they must be his, her assertion was repeatedly combated, as if the peculiar style and manner of his muse were not instantly apparent.

\section{ON A TARGET AT DRAKELOW.}

With silvan bow, on Drakelow's shadowy green, Arm'd like Diana, trod the Cyprian Queen; O'er her fair brow the beamy crescent shone, And starry spangles glitter'd round her zone;

Love's golden shafts her snow-white shoulders press'd, And the fring'd ribbon cross'd upon her breast.

With careless eye she view'd the central ring, Stretch'd her white arms, and drew the silken string!

Mute wonder gaz'd the brazen studs betwixt;

Full in the boss the flying arrow fix'd!

Admiring circles greet the victor fair, And shouts of triumph rend the breezy air; Trent, with loud echoes thrills the flowery grounds, And Burton's tower's retur'n applausive sounds. 
The graceful Huntress eyes the gaudy grove, And bends again th' unerring bow of Love.

Now guard your hearts, with playful malice cries, And wing'd with smiles the shining arrow flies; Witlr random aim the dazzled crowd she wounds,

The quiver'd heroes strow the velvet grounds;

Beau after beau expiring, prints the plain, And Beauty triumps o'er the archer train.

Now, with light bound, she mounts her wreathed car, Rolls her blue eyes, and waves her golden hair. Fond youths bow homage as the wheels proceed, Sigh as they gaze, and call the goddess, SNEYD.

There are beautiful lines in this little composition, but it is not faultless. The fourth and fifth couplets form the most striking and elegant picture which poetry can exhibit of a graceful young woman employed in arrow-shooting. The epichet careless has the accustomed felicity of this author, in giving character to his portraits; since it implies that perfect conscionsness of skill which precludes all strain and effort of attitude, so prejudicial to grace! In these verses Miss Sneyd is described as sending the arrow from the yew, as Dryden makes. Cleopatra cist from her eyes the darts of Love, on her royage down the Cydnus :

As if secure of all Beholders' hearts,

Neglecting she might take them。. 
The metaphoric shooting which succeeds to acclamations for the fair-one's victory, had perhaps better have been omitted. "Beau after beau," sounds equivocally to the ear, in a scene thronged with bows and arrows; besicles, beau is in itself an effeminate and uncharacteristic title for a number of young men in the uniform of Woodmen, and in manly sport with a weapon, dignified by its ancientry, and by which Britons of old not only slew the wild boar and the stag, but repelled their foes when warriors cried aloud in the battle,

Draw, Archers, draw your arrows to the head!

There is also somewhat too much splendor in the departure of the Conqueress, for why should her vehicle be wreathed? A silver arrow, and not a garland, is the costume of archery reward. However, the final couplet is elegant; the eulogy closing with the name of its subject has an happy effect.

Soon after the death of that variously-charming Poet, Mason, Dr. Darwin wrote an Epitaph which he designed should be engraven on his monument. We may be certain, however, that it has not there been inscribed. As an inscription for an urn in a garden or grove, alter a few of the lines for that purpose, and the verses are exccllent; 
though, from being utterly without religious hope or trust, they are improper for a tomb-stone.

\section{FOR THE MONUMENT OF THE REV. W. MASON,}

\section{BY DR. DARWIN.}

These awful mansions of the honor'd Dead

Oft shall the Muse of Melancholy tread;

The wreck of Virtue and of Genius mourn,

And point, with pallid hand, to Mason's urn.

Oft shall she gather from his garden bowers,*

Fictitious foliage and ideal flowers;

Weave the bright wreath, to worth departed just,

And hang unfading chaplets on his bust;

While pale Elfrida, bending o'er his bier,

Breathes the soft sigh and sheds the graceful tear;

And stern Caractacus, with brow depress'd,

Clasps the cold marble to his mailed breast.

In lucid troops shall choral Virgins throng,

With voice alternate chaunt their Poet's song,

And, $\mathrm{O}$ ! in golden characters record

Each firm, immutable, immortal word!

Those last two lines from the final chorus of Elfrida, admirably close this tribute to the memory of him who stands second to Gray as a lyric Poet; whose English Garden is one of the happiest efforts of didactic verse; containing the purest elements of horticultural taste; dignified by sentiments of freedom and virtue; rendered interesting by episode, and given in those energetic and undulating

* Alluding to the Poem, English Garden. 
measures which render blank verse excellent; whose unowned satires, yet certainly his, the Heroic Epistle to Sir William Chambers, and its Postscript, are at once original in their style, harmonious in their numbers, and pointed in their ridicule; whose Tragedies are the only pathetic Tragedies which have been written in our language upon the severe Greek model. The Samson Agonistes bears marks of a stronger, but also of an heavier hand, and is unquestionably less touching than the sweet Elfricla, and the sublime Caractacus.

Since these pages were in the press, an Epitaph on General Wolfe first met their author's eye in a collection of manuscript poetry; and it bears Dr. Darwin's signature. Perfectly in his manner, she cannot doubt its authenticity; else the names of deceased people of eminence are so often affixed to compositions they never framed, that we ought to look jealously at all which do not carry to the mind of the reader internal cvidence of their imputed origin. But for such evidence the ensuing lines had found no place on these pages.

ON THE DEATH OF GENERAL WOLFE.

Thy trembling hills, Quebec, when Victory trod,

Shook her high plume, and wav'd her banner broad;

Saw Wolfe advance; heard the dire din of War.

And Gallia's genius shrieking from afar, 
With fatal haste th' astonish'd Goddess flew, To weave th' immortal chaplet for his brow. Cypress she gather'd with the sacred bays, And weav'd the asp of Death among the sprays. They fly! they fly! th' expiring Hero cried, Hung his wreath'd head; thank'd the kind Gods, and died.

Will the reader again extend indulgence to the spirit of authorism, tenacious beneath a sense of recent injury? As in the course of this little work its writer has claimed her own verses from the splendid poem she anaylysed, so will he now permit her to disclaim other verses, that, by singular effrontery (her existence considered) have been printed since, with her name affixed. In the Spring 1803, she sent these memoirs to $\mathrm{Mr}$. Johnson for publication; she now, January 1804, but first discovered an illegitimate Sonnet in one of the Gentleman's Magazines for August or September last, with her signature at full length. It is addressed to Mr. Dimond, of whose poetic existence she had never heard, and it praises a poem of his which she has never seen. One line of the forged sonnet begins, "Bright Dimond," thus making a miserable pun from an unfortunate name; and the writer's ear was defective enough to induce his alliterating with the harsh th thus, 
Young joys awake in many a thrilling throng;

which last words form completely the Gander's hiss.

She finds also that these alternately-rhyming stanzas, which call themselves sonnet, are interpolated, and given as her's, in the 6th Vol. of Public Characters, recently published, see page 554 of that Vol. They close anecdotes of her, that have been chiefly collected from previous tracts in the monthly publications. All are of much too partial description; and strangely indeed is the talent of singing agreeably attributed to her, who, conscious of total want of voice, never attempted to sing in her whole life. Amid , these latest anecdotes a stanza is quoted from her "Ode to General Elliot on his return from "Gibraltar," and the quotation has two gross misprints, "inclustrious soldier" for illustrious soldier, and " honour to the lap of peace," instead of, honour on the lap of peace.

When this sonnet-forgery was contrived, its writer forget that she, whose name was affixed to it, had, in her Preface to the Centenary of legitimate Sonnets, which she published in 1798, denied to three alternately rhyming stanzas, closing with a couplet, all right to the name of that 
peculiar and strict order of verse. It was therefore most unlikely that she should herself assume it for fourteen lines, written on the feeble model which she had reprobated.

But it is time to resume a more interesting subject.

The close of the year 1799 brought a severe trial to the stoical fortitude of Dr. Darwin. From the period of his second marriage all had been sunshine in his fortune, his fame, and domestic connexions; but then a storm descended upon his peace; unforeseen, sudden, dreadful! His eldest son, Mr. Darwin, so prosperously situated, without one adequate cause for even transient affliction, became the victim of secret and utter despair. It had often been observed that any more than ordinary recurrence of professional business perplexed and oppressed him. A demand was made that he should arrange and settle some complicated accounts, which a disposition to procrastinate had too long delayed. A disposition which is always, in a greater or less degree, punished by its consequences. Though a remote, it is the most frequent cause of suicide, accumulating debts till their entanglement becomes inextricable, their weight too heavy to be borne. But in this case it had produced only an accumu. 
lation of business. From the necessity of entering upon it Mr. Darwin had seemed to shrink with so much dejection of spirit as to induce his partner to intreat that he would leave the inspection solely to his management. He declined the proposal, saying, in a faint voice, that it was impossible.

This was on a December evening, cold and stormy. The river Derwent, which ran at the bottom of his garden, was partially frozen. About seven o'clock he sent his partner out of the way on business real or pretended. Mr. Darwin was on the couch complaining of the head-ach, Soon after eight his partner returning found the parlour vacant. He went to Mr. D's upstair apartment, vacant also, inquired of the servants; they had not seen their master since this gentleman went out, an hour before. He waited a few minutes expecting his friend's return from the garden. Not appearing, a degree of apprehension seized his mind. He ran thither, and in the walk which leads to the river, he found $\mathrm{Mr}$. Darwin's hat and neckcloth. Alarm was immediately given, and boats were sent out. Dr. Darwin had been summoned. He staid a long time on the brink of the water, apparently calm and collected, but cloubtless suffering the most torturing anxiety. The body could not be found till the next day. 
When the Dr. received information that it was found, he exclaimed in a low voice, "Poor insane " coward!" and it is said never afterwards mentioned the subject.

Mr. Darwin died in very good circumstances, leaving an untainted reputation for probity and benevolence; beloved, respected, and mourned by all who knew him. He never married; had purchased a pretty estate near Derby, which, with all his other effects, he left to his father. The accounts, whose apprehended embarrassment had proved fatal to him, were settled after his death to the satisfaction of all parties.

Though this unfortunate victim of causeless despondency had a gentle, ingenuous, and affectionate heart, he attained middle life without any known or suspected attachment of the impassioned kind. There seemed a want of energy in his chaw racter, and too extreme a delicacy of feeling on the occurrence of every thing which was in the slightest degree repulsive. He had never loved business, and his attention to it appeared a force upon his inclinations. While his profession was undetermined, he expressed a wish to go into the church rather than the law. That preference was repulsed by paternal sarcasms upon its indolence and imputed effeminacy. From infancy to his last day, Mr. Dar. 
win had shrunk, with pained sensibility from his father's irony. Probably from the less active, less scientific disposition of Erasmus, in comparison with that of his brothers Charles and Robert, Dr. Darwin had always appeared colder towards him than to his other children. Doubtless it was that inferior degree of attachment which made the lesson of stoicism somewhat more practicable on this trying, this dire occasion. It excited, however, universal surprise to see him walking along the streets of Derby, the day after the funeral of his son, with a serene countenance and his usual cheefulness of addréss. This self command enabled him to take immediate possession of the premises bequeathed to him; to lay plans for their improvement; to take pleasure in describing those plans to his acquaintance, and to determine to make it his future residence; and all this without seeming to recollect to how sad an event he owed their possession!

The folly of suffering our imagination to dwell on past and irretrievable misfortunes, and of indinging fruitless grief, he often pointed out, and always censured. He relied much on self-discipline in that respect, and disdained, from deference to what he termed the prejudices of mankind, to display the outward semblance of unavailing sorrow, since he thought it wisdom to combat its 
reality. On occasions and subjects which he considered trivial, he professed to indulge human prejudice; but whenever, by mock assent, he extended that indulgence, a slight satiric laugh and a gay disclain lurking in his eye, counteracted the assumed coincidence. On circumstances which touched him nearly, he acted steacily upon his own principles.

And there were subjects out of himself on which he was always seriously and earnestly ingenuous. Politics was one. He hated war, and thought the motives few indeed which could vindicate its homicide, especially in this commercial and sea-clefended country. 'That of forcing America into internal, unrepresented taxation, and of interfering, through jealousy of her principles, with the internal government of France, he utterly disapproved. The event of both those contests accomplished his prophecies, and justified his disapprobation.

Early in the year 1800, Dr. Darwin published another large quarto volume, entitled Phytologia, or the Philosophy of Agriculture and Gardening. The writer of these pages does not presume to speak her opinion of this production as an whole; the subject did not induce her to read it regularly. Incompetent therefore to declared opinion as her 
perusal may have been, it has yet convinced her that in parts, at least, it is highly ingenious. Dr. Darwin's conviction that vegetables are remote links in the chain of sentient existence, often hinted in the notes to the Botanic Garden, is here avowed as a regular system. The Phytologia insists that plants have vital organization, sensation, and even volition; and a number of instances are adduced, which seem firmly to support the theory. Certainly those appear to sleep which close their petals at sun-set, and unfold them in the rising day. Dr. Darwin tells us that plants possess low heat and cold blood, like winter-sleeping animals, and like them continue the descending scale of existence.

From this theory of vegetable sensation some good may proceed, and no evil can flow. If the affluent improver of his paternal or purchased domain, shall be impressed with its belief, such impression must augment his pleasure in attending to the sustenance, the growth, and comfort of his trees, his grain, his shrubs, and his flowers. He will say to himself, "It is I who enable this" little "world of vegetation, by my care, attention, and "kindness, to smile upon the sun, and bask delight"ed in its rays." The labourer in the field and garden, assured that the grain and the plants he is cultivating will not only nurture his fellow crea- 
tures, but are themselves capable of receiving com. fort or discomfort while yet they grow on the earth, will thence feel an additional motive to become worthy of his hire. Every honest heart is gratified by the idea of contributing to the common stock of happiness. It is an idea which produces self-re.spect in the mind, which, when founded in benevolence, and not in haughtiness, is the fairest and most productive soil in which the virtues can grow, whether those virtues be lowly and plain in ignorance and poverty, or heightened and refined by knowledge and affluence.

Of this theory, however, Dr. Darwin is neither the source, nor the first who drew the scattered hints of former philosophers concerning it, into a regular system. The ingenious and excellent Dr. Percival, of Manchester, preceded him in main. taining that system from the press. Congeniality on its subject between a mild,' a temperate, and religious sage, and a bold philosopher of the modern school, who possessed the eye of a lynx for: nature's arcana, leave us little reason to doubt that it is veritable. Why should we suppose the chain of existence broken at the last, inert class of animals, since its continuity is perfectly consonant to the order of creation? 
The chain that leads from infinite to man,

From man to nothing.

\section{Night Thovghs.}

The nourishment of plants is next considered with a view to their health and increase; and ingenious experiments are stated. The decomposition of water is asserted to be one of the most important discoveries of modern science. Thence was demonstrated the immense proportion of oxygene or vital air, with which water is impregnated, in comparison with air which is less pure. A plentiful supply of water absolutely necessary to fertilize soil. The wisdom asserted, and the means pointed out, of giving artificial and salutary moisture to arid situations. On the contrary, where the ground is naturally too wet and swampy, the necessity of subterranean and superficial drains is enforced. Sudden and violent showers extremely detrimental, from their washing down the diffusable and soluble parts of the soil into muddy rivers. It is observed, that every such shower conveys through those channels into the sea, many thousand pounds - worth of fertilizing matter, thus considerably diminishing the food of terrestrial animals, however it may add to the sustenance of the aqueous tribes. 
Creat attention is necessary to counteract the mischief of these impetuous and impelling rains, equally noxious to the dry soil and situation, as to those which are irriguous. To such end we are informed that all hills should be ploughed horizontally, and not in ascending and descending furrows; also, that sloping fields of pastureland might be laid in transverse ridges and depressions. Thus the water of these partial inundacions would remain some hours in the horizontal furrows of the ploughed hills, and in the transverse hollows of inclined plains, that are grassland. These little cetaining reservoirs must be a great advantage in parched situations, while in those which are spongy, they might be opened into each other by the spade, so as to prevent that loss of soil which must result from the downward rush and speedy passing away of the temporary deluge. The great waste in towns and cities, of sübstances capable of being converted into manure, is observed and cleplored; and in that respect the better police of China held up to imitation. The author alleges, that similar practice in Europe would at once promote the purity and consequent health of tornns, and contribute to the economy and fertility of the surrounding countries. He explains the means of accomplishing purposes so desirable. 
Here let the biographic pen arrest its course, nor attempt to follow this penetrating and excursive mind through the wide and complicated mazes of agricultural dissertation. Returning back to the verge of this vast field of treasured observation and scientific literature, the memorialist may be allowed to observe what never-slumbering attention to the operations of nature and the present state of cultivation; what unwearied research into the records of other philosophers, this book evinces! A man of such immense professional engagements as Dr. Darwin, composing and publishing this work only, had built his lettered reputation upon no narrow or unstable basis. But when we consider it as a brother-production to the Zoonomia, two large quartos, as bulky, as small a type, and as crowded writing as the Phytologia; when we consider also his splendid poetic work, with its host of philosophic notes; there is surely no partiality to him, no want of candor to others, in maintaining that it can only be from native littleness or acquired warp of mind, where the greatness and energy of Dr. Darwin's genius and knowledge are denied. Yet let it be remembered, that it is poetic eminence and not pre-eminence, which has here been demanded for his muse. Superlative epithets have found no place in his eulogium on these pages; for their author 
remembers and revers the exalted claims of his poetic predecessors and contemporaries of the eighteenth century. Incomparable, unrivalled, matchless, are terms of applause which can only be, with truth, applied to three men of genius in times past; to Shakspeare as a dramatic poet; to Newton as a philosopher; to Handel as a musician; not to Homer, not to Milton, since they stand abreast with each other, and divide the epic palm. Perhaps, without trespass on literary truth, Gray might also be termed peerless, as a lyric poet, since he equals Pindar in the dignity of his language, in the sublimity of his imagery, and in the interwoven morality, alternately awful and tender; and since he chose subjects so much more exalted than the Pindaric themes, for those two great Odes which place him first at the goal of the Lyric Muse. Their measures are magnificent and harmonious to the utmost power of the English tongue. Pindar could not carry that excellence higher in the Greek language; therefore if any superiority remains to the ancient classic, respecting his metre, it must result from the more sonorous tones of the Greek, not from transcendence of genius in its great lyrist, compared with the British poet. Whatever importance the fashion of that period might attach to Pindar's themes, however 
mythologic and historic allusion might give them auxiliar elevation, yet the foot-races of children, though the sons of princes, and the chariot-races of youthful heroes, possess no eternity of attraction compared to the subject of Gray's Progress of of Poesy, and of his Bard. For the first, the physi$\mathrm{cal}$ and moral powers of the muses; their universal influence, in different degrees, in every clime; the three great seats of their empire, Greece, Italy, and England, Dramatic, Epic, and Lyric Poetry, supported in Britain by Shakspeare, Milton, and Dryden.

For the second, and still greater Ode, the sanguinary crime against the Muses committed by an otherwise illustrious monarch, the supposed consequences of that crime, a train of misfortunes to the remaining line of the Plantagenets; its regal sons,

Another and another gold-bound brow,

passing before us in the awful obscurity, the " darkness visible" of poetic prophecy; the accession of another royal house, in which the riral roses were entwined; the brilliant reign of its virgin queen, who was to carry the prosperity and the renown of a great nation to its utmost line; the 
day of poesy, sunk in eclipse from the period of the massacre, rising again with redoubled splendor in that epoch; the exaltation of the Cambrian Bard who thus foresees the restored glory of his art in the genius of him who sung the fairy region, and by that of the mighty master of the sock and buskin; the continuance of that glory through future times by the Song of Eden, and the strains of successive warblers; the cxultation closing by the plunge of the injured Bard amid Conway's deep and tumultuous flood! Can pedestrian speed, and the dexterity of the whip and rein, by any effort of talent, be raised to the intrinsic grandeur of themes like these? Ah! when will our schools and universities, exchange classical partiality for patriotism, and become just to the exalted merits of the English Poets? 'To that sincere and ardent patriotism the author of these memoirs hopes will be remitted her tributary digression to the fame of Gray.

Sunday, the eighteenth of April, 1802, deprived Derby and its vicinity, and the encircling counties, of Dr. Darwin; the lettered world of his genius. During a few preceding years he had been subject to sudden and alarming disorders of the chest, in which he always applied the lancet instantly and freely; he had repeatedly risen in the night and oled himself. It was said that he sus. 
pected angina pectoris to be the cause of those his sudden paroxysms, and that it would produce sudden death. The conversation which he held with Mrs. Darwin and her friend, the night before he died, gave colour to the report. In the preceding year he had a very dangerous illness. It originated from a severe cold caught by obeying the summons of a patient in Derby, after he had himself taken strong medicine. His skill, his courage, his exertion, struggled vehemently with his disease. Repeated and daring use of the lancet at length subdued it, but, in all likelihood, irreparably weakened the system. He never looked so well after as before his seizure; increased debility of step, and a certain wanness of countenance, awakened those fears for him which great numbers felt who calculated upon his assistance when hours of pain and danger might come. It was said, that during his illness he reproved the sensibility and tears of Mrs. Darwin, and bid her remember that she was the wife of a philosopher.

The public papers and magazines recorded, with tolerable accuracy, the nature of his final seizure; the conversation he held in the garden of his new residence, the Priory, with Mirs. Darwin and her female friend; the idea which he communicated to them, that he was not able to live 
to see the effect of those improvements he had planned; Mrs. Darwin affectionately combating that idea by observing, that he looked remarkably well that evening; his reply that he had generally found himself in his besthealth a few days preceding his attacks; the spirits and strength with which he arose the next morning at six to write letters; the large draught of cold butter-milk, which, according to his usual custom, he had swallowed. All these circumstances early met the public eye ; and, in the imperfect sketches of his life which accompanied them, a strange habit was imputed to Dr. Darwin, which presents such an exterior of idiot-seeming indelicacy that the author of this tract is tempted to express her entire disbelief of its truth; viz. that his tongue was generally hanging out of his mouth as he walked along. She has often, of late years, met him in the streets of Lichfield, alone and musing and never witnessed a custom so indecent. From the early loss of his teeth he looked much older than he was. That loss exposes the tongue to view while speaking, and Dr. Darwin's mouth certainly thus disclosed the ravages of time, but by no means in any offensive degree.

It was the general opinion that a glass of brandy might have saved him for that time. Its effects would have been more powerful from his utter dis41 
use of spirits; but such was the abhorrence in which he held them, that it is probable no intreaties could have induced him to have swallowed a dram, though surely, on any sudden chill of the blood, its effects, so injurious on habitual application, might have proved restoring.

On that last morning, he had written one page of a very sprightly letter to Mr. Edgeworth, describing the Priory; and his purposed alterations there, when the fatal signal was given. He rang the bell, and ordered his servant to send Mrs. Darwin up to him. She came immediately, with his daughter, Miss Emma Darwin. They saw him shivering and pale. He desired them to send directly to Derby for his surgeon, Mr. Hadley. They did so, but it was all over before he could arrive.

It was reported at Lichfield, that, perceiving himself growing rapidly worse, he said to Mrs. Darwin, "My dear, you must bleed me instantly." "Alas, I dare not, lest...." " Emma, will you? " There is no time to be lost." "Yes, my dear "father, if you will direct me." At that moment, he sunk into his chair, and expired!

The body was opened, but it was said the surgeons found no traces of peculiar disease; that the state of the viscera indicated a much more pro: 
tracted existence; yet thus, in one hour, was"extinguished that vital light which the preceding hour had shone in flattering brightness, promising duration;"such is often the "cunning flattery of nature;" that light, which through half a century, had diffused its radiance and its warmth so widely; that light, in which penury had been cheered, in which science had expanded; to whose orb poetry had brought all her images; before whose influence disease had continually retreated, and death so often turned aside his levelled dart!

Awful is the lesson of such an extinction; trebly awful in its suddenness. Let no one say that it is not more awful than the similar destiny of ordinary human beings; ; for the impression made by unexpected, immediate and everlasting absence, will be diffusive, will be strong, in proportion to the abilities and usefulness of those who vanish at once from society. We feel the solemn lesson sink deep into our hearts, when minds, so largely endowed and adorned, evince, in their fate, the truths uttered by that sublime Poet*, who made the threats and the promises of the Gospel the theme of his midnight strains; and thus they admonish,

By nature's law, what must be, may be now;

There's no prerogative in human hours.

* Dr. Young. 
In human hearts what bolder thought can rise

Than man's presumption on to-morrow's dawn?

Where is to-morrow ?....In another world!

For numbers this is certain, the reverse Is sure to none; and yet, on this perhaps, This peradventure, infamous for lies, As on a rock of adamant, we build;

Though every dial warns us as we pass, Portentous as the written wall, that turn'd, O'er midnight bowls, the proud Assyrian pale!

Another, and the last poetic work of Dr. Darwin, is now in the press. The Temple of Nature. His memorialist, on these pages, has not seen a line of the composition. The curiosity of the ingenious must be ardently excited to view the setting emanation of this brilliant day-star; they must hope that neither age, disease, nor the dread calamity he had endured, in December 1799, shed mist or cloud upon its rays.

Dr. Darwin died in his sixty-ninth year.

This Tract is presented to the Public beneath its author's idea, that it may probably displease two classes of readers, should it attract their notice; the dazzled idolaters of the late Dr. Darwin, who will not allow that there were any spots in his sun; and that much larger class, who, from party prejudice, religious zeal, or literary envy, or a combination of all those motives, are unjust to his claims; 
at least as a Philosopher and Poet. There is another class of readers, who, if these faithful records shall be honoured by their perusal, will feel gratified to see one distinguished character of these times, neither varnished by partiality, nor darkened by prejudice. They must be conscious that human beings, whatever may have been their talents, whatever their good qualities, are seldom found perfect, except on the pages of their eulogists; conscious also, that, while the intellectual powers of the wise and the renowned, excite admiration, their errors may not less usefully be contemplated as warnings, than their virtues as examples.

LIGHFIELD,

April 13, 1803. 



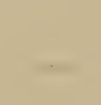

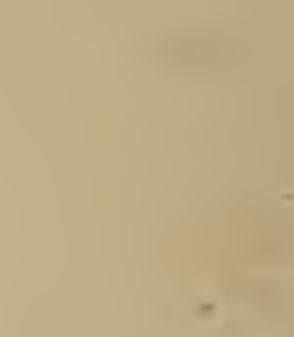

5

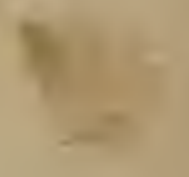

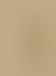






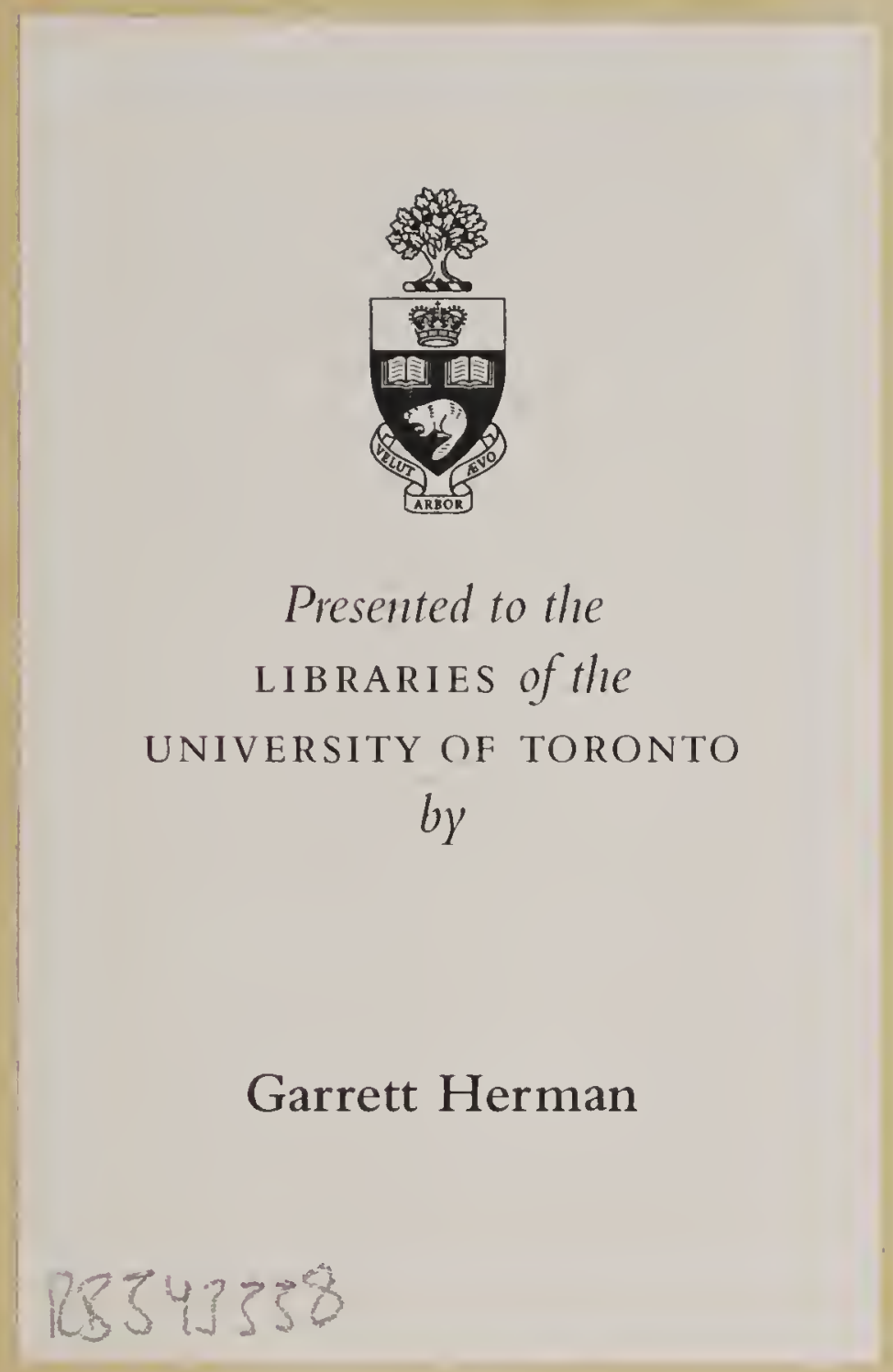




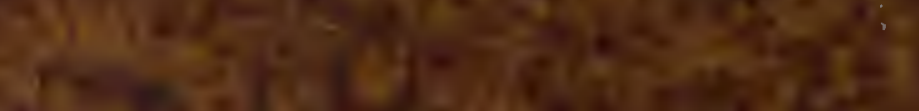

2.5.

2.

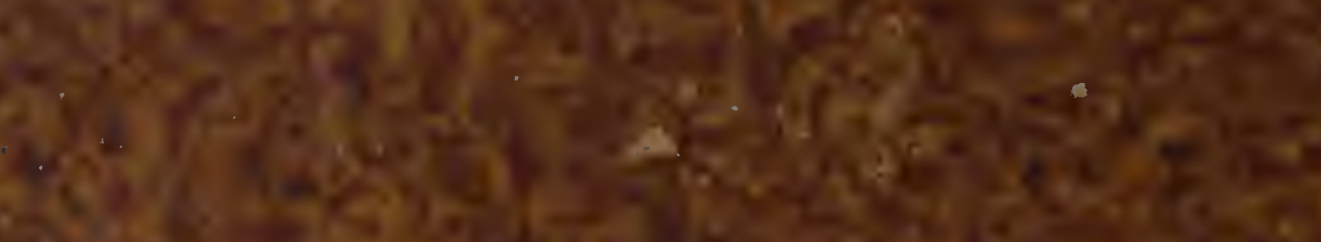

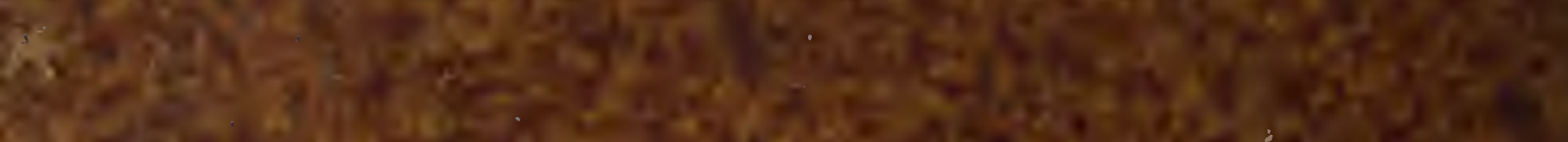

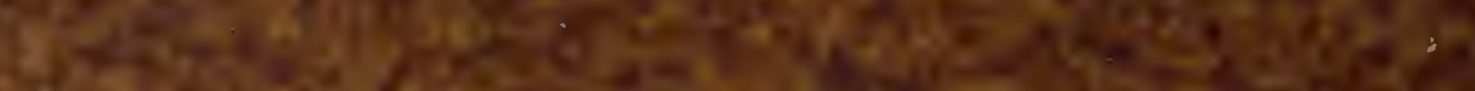

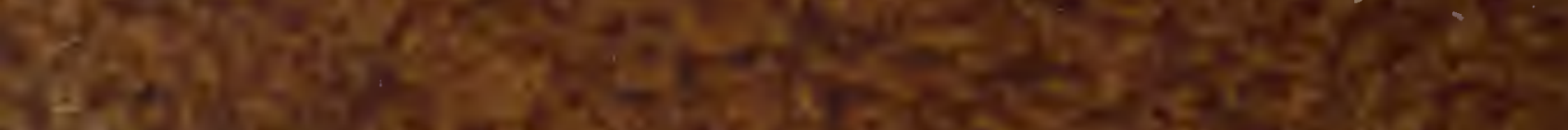

W.

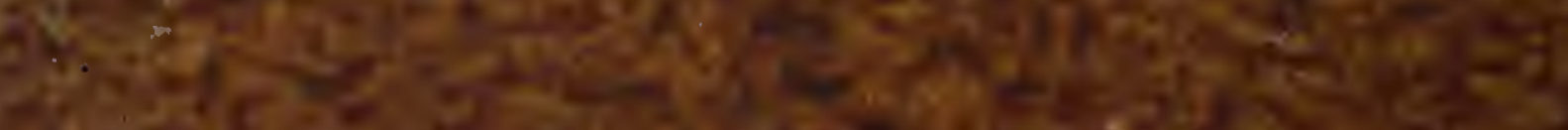
Whith:F

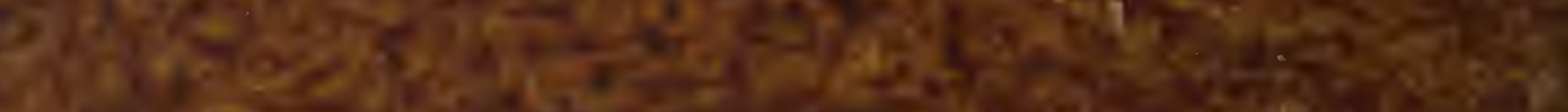

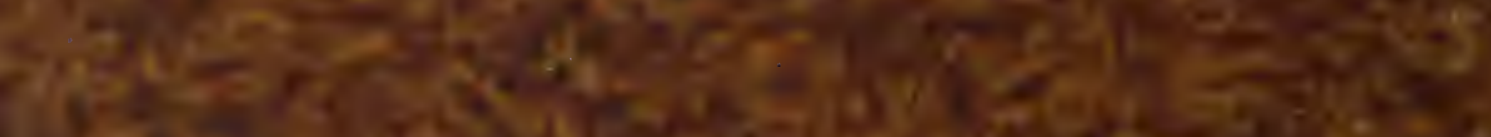

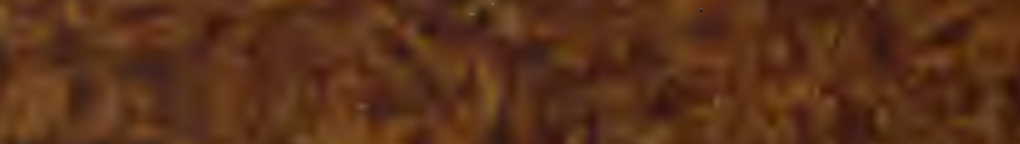
(20)

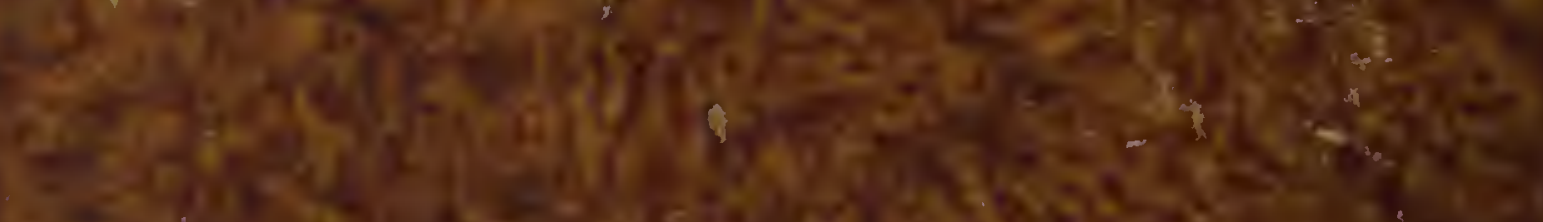

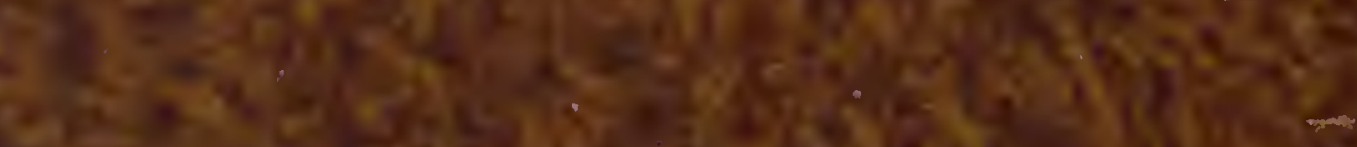

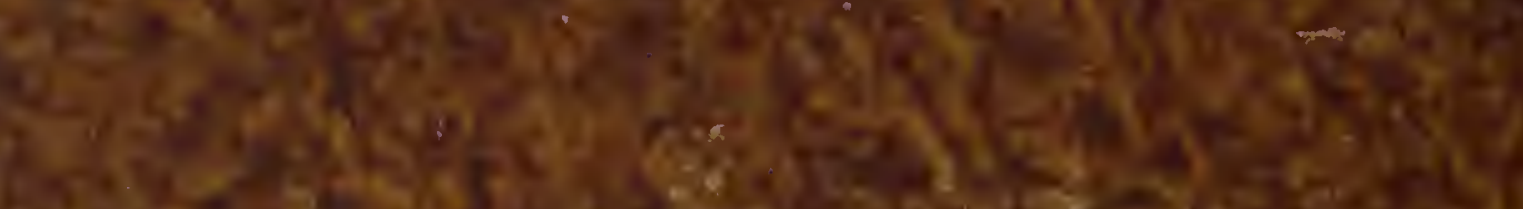

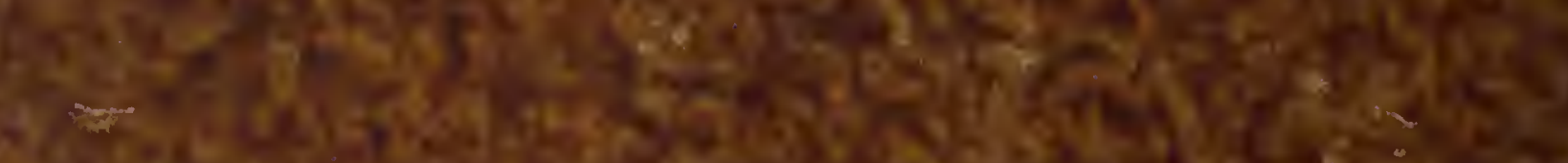

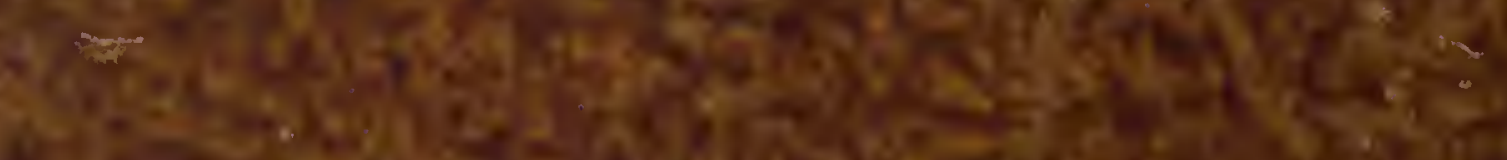

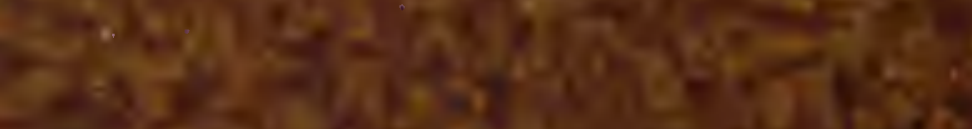

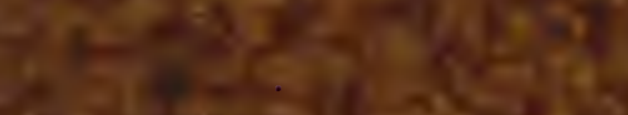

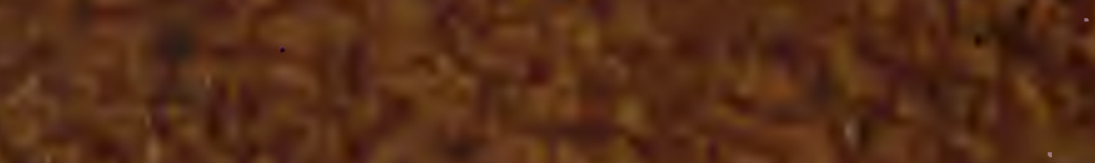

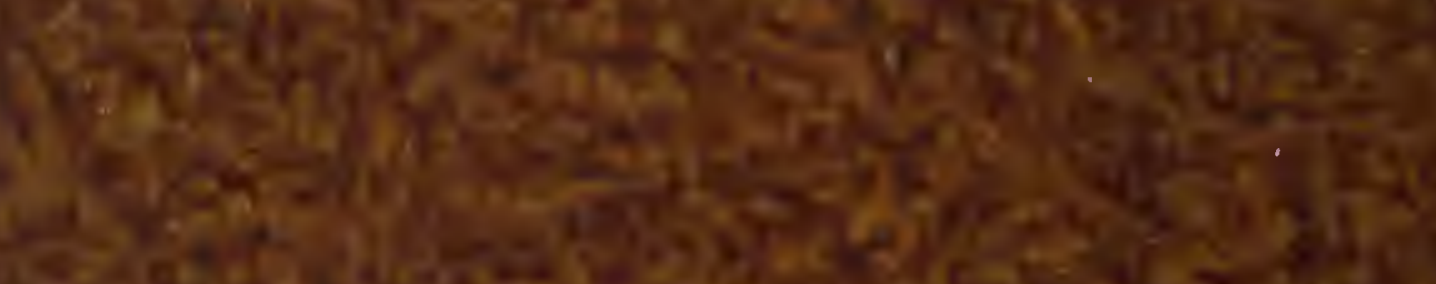

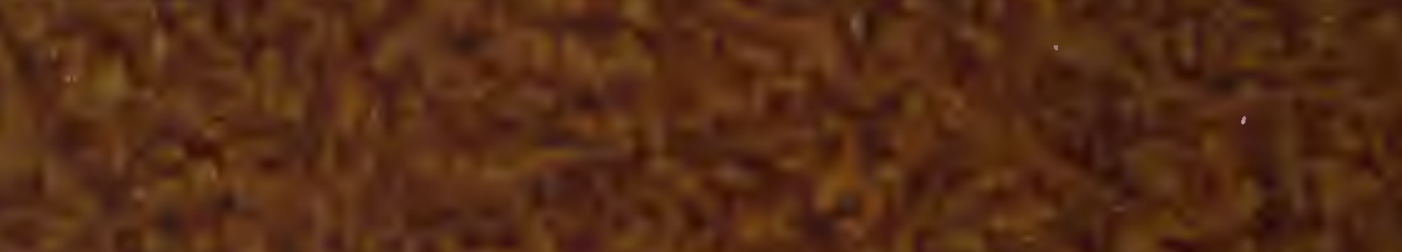

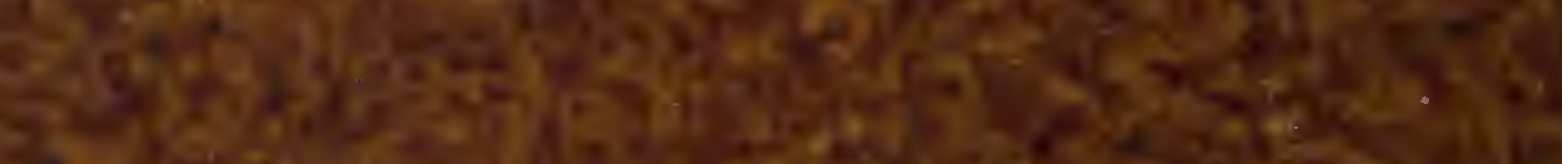

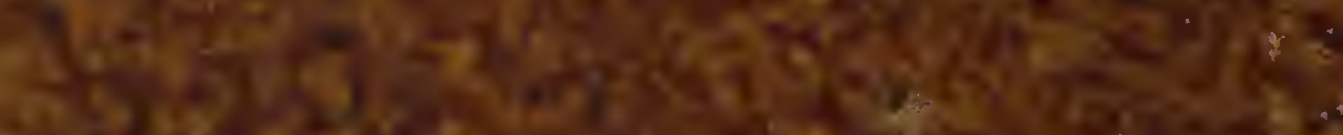

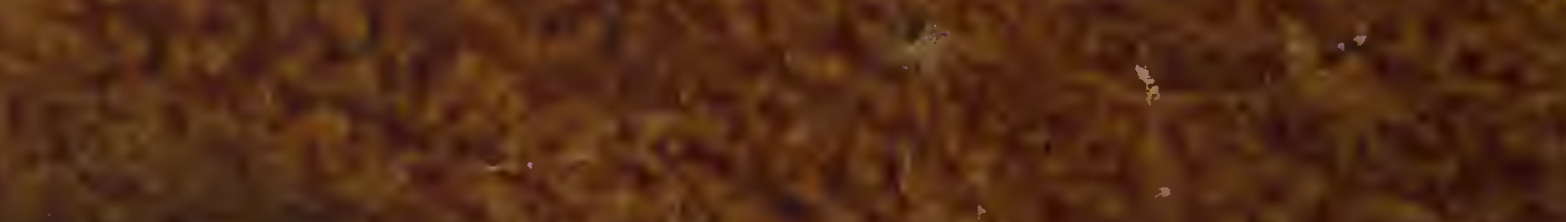

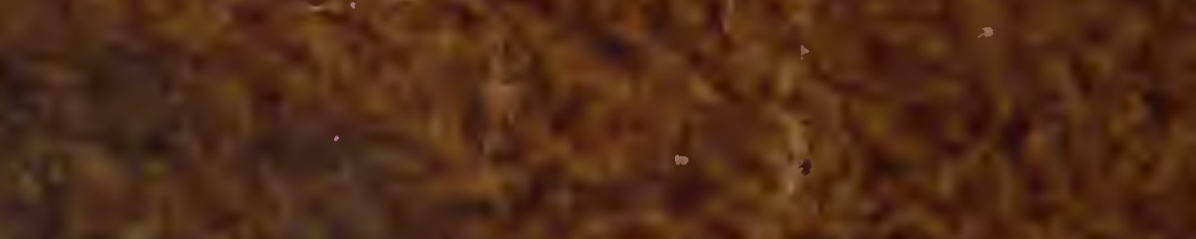

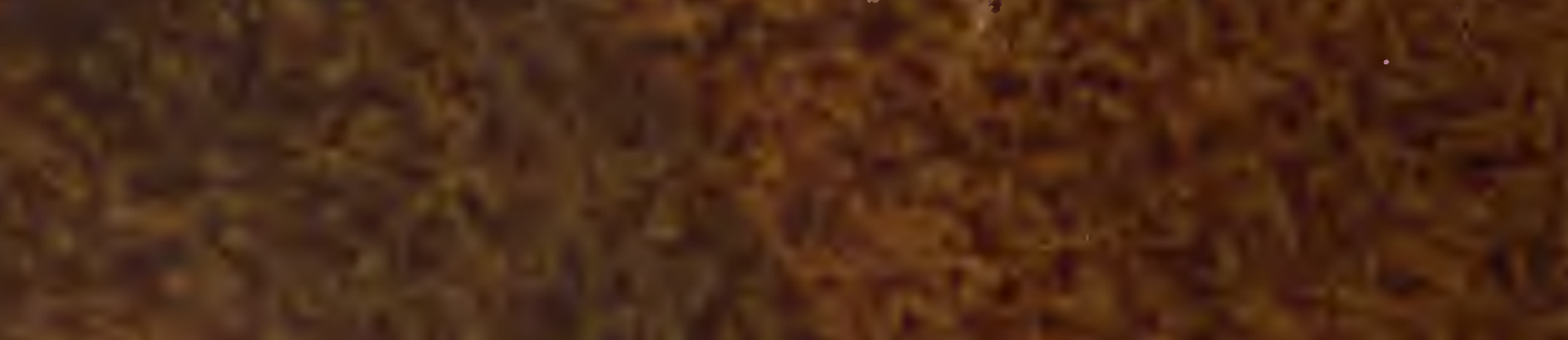

H. 